\title{
WestVirginiaUniversity
}

THE RESEARCH REPOSITORY @ WVU

Graduate Theses, Dissertations, and Problem Reports

2012

\section{Russian-Moldovan Relations after the Collapse of the Soviet Union}

Anna Napieralska

West Virginia University

Follow this and additional works at: https://researchrepository.wvu.edu/etd

\section{Recommended Citation}

Napieralska, Anna, "Russian-Moldovan Relations after the Collapse of the Soviet Union" (2012). Graduate Theses, Dissertations, and Problem Reports. 257.

https://researchrepository.wvu.edu/etd/257

This Thesis is protected by copyright and/or related rights. It has been brought to you by the The Research Repository @ WVU with permission from the rights-holder(s). You are free to use this Thesis in any way that is permitted by the copyright and related rights legislation that applies to your use. For other uses you must obtain permission from the rights-holder(s) directly, unless additional rights are indicated by a Creative Commons license in the record and/ or on the work itself. This Thesis has been accepted for inclusion in WVU Graduate Theses, Dissertations, and Problem Reports collection by an authorized administrator of The Research Repository @ WVU. For more information, please contact researchrepository@mail.wvu.edu. 


\title{
Russian-Moldovan Relations after the Collapse of the Soviet Union
}

\author{
Anna Napieralska
}

Thesis submitted to the Eberly College of Arts and Sciences

at West Virginia University in partial fulfillment of the requirements for the degree of

Master of Arts

in

History

Robert Blobaum, Ph.D. (supervisor)

Katherine Aaslestad, Ph.D.

Elizabeth Fones-Wolf, Ph.D.

Department of History

Morgantown, West Virginia

2012

Keywords: Russian Foreign Policy; Russian-Moldovan Relations;

Moldovan Foreign Policy; International Relations 


\section{ABSTRACT \\ Russian-Moldovan Relations after the Collapse of the Soviet Union Anna Napieralska}

After the break-up of the Soviet Empire a newborn Republic of Moldova faced a series of challenges, one of which was creating the political and economic foundations that would allow it to become the sustainable European country. It proved to be an extremely difficult task. Indeed, at the beginning of the 1990's Moldova was widely known as the poorest and the least economically stable country on the old continent. During the first years of independence the Moldovan leaders realized that the greatest challenge would be to limit Russian influences on the domestic and foreign policy of the country. Since the Russian Federation, the principal successor state of the Soviet Union, considered Moldova to be of the highest strategic importance it wanted to ensure that Moldova would remain under the Russian sphere of vital interests. Unfortunately for Moldova it also meant that Kremlin wanted it to remain impoverished and divided, and thus, easier to control. Support for the self-proclaimed Dniestrian Moldovan Republic became one of the effective tools of Moscow in pursuing its own vision of Kishinev's position on the European scene.

The current study presents the Russian foreign policy strategy toward the Republic of Moldova after the collapse of the Soviet Union and shows how the weak and small country had to struggle with outside influences on its domestic affairs. It also argues that it has been in Russia's best interests to maintain the current Moldovan status quo in order to be able to prevent it from strengthening cooperation with Western players, particularly NATO and the EU. The study examines in detail the various mechanisms of Russian foreign policy that were aimed at balancing the Western influences in Moldova. Finally it argues that for over the past twenty years the Kremlin has not hesitated to use blackmail, especially on trade issues, which has significantly inhibited the Moldovan process of transformation into a democratic and sustainable state. 


\section{Acknowledgments}

\section{Morgantown, 2012}

Funding for my thesis and my MA studies at West Virginia University, Collegium Civitas, and the University of Tartu was made possible by the Transatlantic MA Program in EastCentral European Studies, an "Atlantis" project sponsored by the Fund for the Improvement of Secondary Education of the U.S. Department of Education and the European Commission's Executive Agency for Education, Audiovisual and Culture. 


\section{CONTENTS}

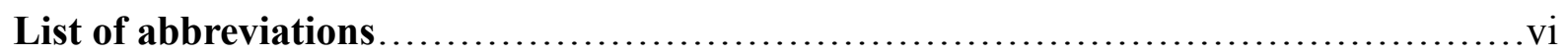

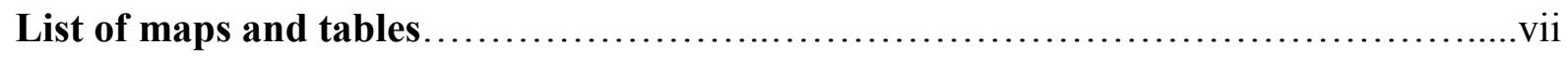

List of maps........................................................

List of tables...............................................................

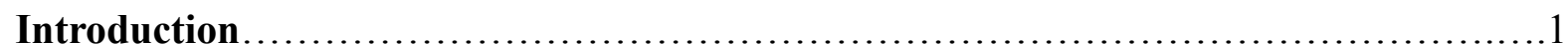

\section{Chapter I.}

Historical Background of Russian-Moldovan relations.................................6

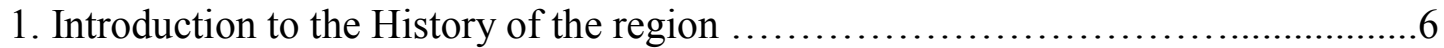

2. The First Annexation of Bessarabia and Russian Rule, 1812 - 1918...............9

3. Soviet Policies on the Romanian Border. Creation of MASSR ...................16

4. Soviet policy vs. Native inhabitants. The Moldovan Soviet Socialist Republic

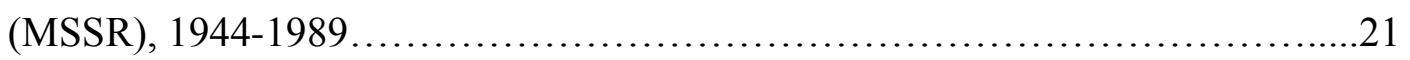

\section{Chapter II.}

The Establishment of the Political and Economic Co-operation. 1989 - 1999...............32

1. On the Path to Independence. 1989-1991 .................................... 32

2. The Relations between Sovereign States. The Transnistrian Conflict...............41

3. Russian Involvement in the Transnistrian War ..............................45

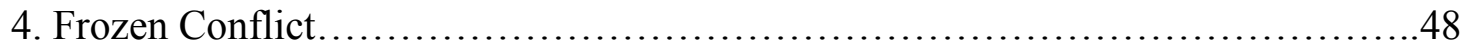

5. The Peace Negotiations............................................................. 51

6. The Russian- Moldovan Relations: Warming Up? .......................54

7. Economic Crisis.......................................................61 


\section{Chapter III.}

The Voronin Era. Moldovan-Russian Relations in the First Decade of XXI Century....66

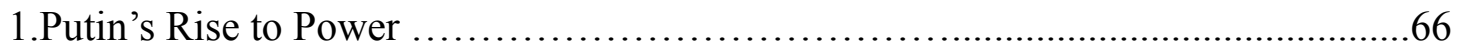

2. Moldovan Communists rise to Power............................................. 70

3. A Great Dissapointment ................................................. 74

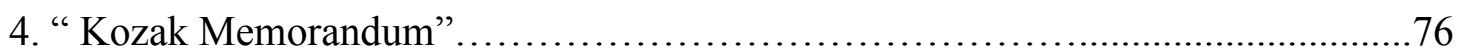

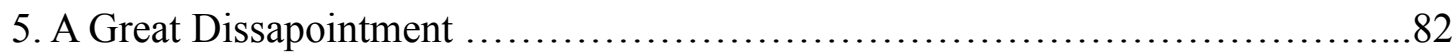

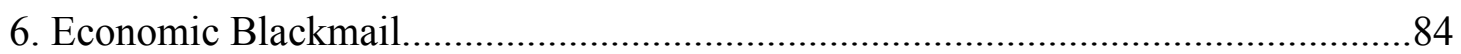

7. East or West? Which Course to Choose?....................................... 88

8. Pleasing Russia.......................................................... 91

9. Elections crisis. Moldovan Communists lose power............................95

Conclusion................................................................................

1. Current Situation in Brief................................................101

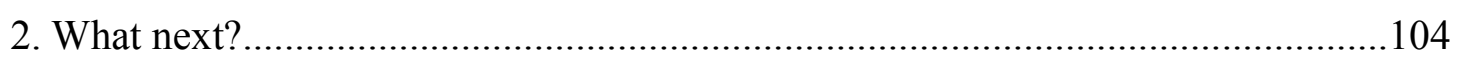

Bibliography....................................................................

Primary sources........................................................ 107

Secondary sources........................................................ 


\section{LIST OF ABBREVIATIONS}

AEI - the Alliance for European Integration

CIS- Commonwealth of Independent States

DMR - The Dniester Moldovan Republic

GDP - Gross Domestic Product

GUAM - The Organization for Democracy and Economic Development

KGB - Russian Committee for State Security

MSSR - The Moldavian Autonomous Soviet Socialist Republic

NATO- The North Atlantic Treaty Organization

OGRF - Operational Group of Russian Forces

OSCE - Organization for Security and Co-operation in Europe

OSTK - The Unions Workers and Collectors

PCRM - The Party of Communists of the Republic of Moldova

RF - The Russian Federation

UE - The European Union

UN - The United Nations

USSR - The Union of Soviet Socialist Republi 


\section{LIST OF MAPS AND TABLES.}

\section{List of maps.}

Map 1. Map 1 The Medieval Principality of Moldova..............................................................

Map 2. The Moldovan Soviet Socialist Republic 1944-1991_................................21

\section{List of tables.}

Table 1. Largest minority groups in Moldova,1989 and 2004...............................33 



\section{INTRODUCTION}

For the citizens of the territories behind the Iron Curtain the collapse of the Soviet Union in 1991 and the changes brought by it signified the beginning of new era. Everything what constituted the existence of the Soviet republics suddenly disappeared: the Central Committee of the Communist Party, the Soviet system of state socialism, Marxist ideology and central planning. The dissolution of the Soviet state resulted in the creation of numerous independent states that had to face several challenges and difficulties which accompanied the transition. ${ }^{1}$ One of the great examples of a post-Soviet country struggling with those difficulties is Republic of Moldova, which declared the independence from the Soviet Union on 27 August 1991. The newborn country already at the beginning of 1990s confronted many of the challenges facing the ex-Soviet republics - economic decline, political turmoil, and inter-ethnic discord ${ }^{2}$. The lack of the political consensus between political leaders regarding economic policies, failed attempts to initiate structural reforms as well as a lack of qualified cadres to serve in the local administration had resulted in the significant deterioration of the economic situation. On the top of Moldova's

\footnotetext{
${ }^{1}$ Manuel Irman, Moldovan Division after the Collapse of the USSR: Russia's Role iln the Transitional Process of Moldova and its Renegade Province Transnistria (Zurich: GRIIN, 2010), p.6.

${ }^{2}$ Charles King, Post-Soviet Moldova: A Borderland in Transition (Chisinou: Center for Romanian Studies, 1997), p. 16.
} 
internal issues, the country had to face the challenging task of establishing relations with the Russian Federation.

Russo-Moldovan relations after the breakdown of Soviet Empire became a main focus of foreign policy conducted by the government in Chisinau. Due to Moldova's geopolitical position, even after the dissolution of the Soviet Union Moscow's stance remained an important factor in the Chisinau decision-making process. Thus, Russian authorities, not surprisingly, have been taking advantage of that position interfering systematically in Bessarabian politics. ${ }^{3}$ As Ella Akerman rightly puts it, "Russia had neither experience nor traditions in establishing interstate relations with the former Union republics, and consequently did not succeed to formulate a positive foreign policy taking into account its national and state interests." 4 Moscow usurped the right to have a major influence in the region, making it "a zone of its vital interest" . One of best examples of Russian politics is its military intervention in the Moldovan civil war in 1992. Thus, Russo-Moldovan relations after 1991 is the focus of this thesis, as an excellent example of how Russians understand their role in post-Soviet space as well as how the post-Soviet country struggles with pleasing its most important international partner.

There are a couple of reasons for which the research on Russo-Moldovan relations is so important. First of all, the shape of relations between Moldova and Russia in the aftermath of the dissolution of the Soviet Union reveals the real attitude of Russian Federation toward the EU and NATO as well as raises important questions about Russian policy toward Europe's newborn

\footnotetext{
${ }^{3}$ Although historically (before the annexation by Russians) the name Bessarabia denoted the area of Moldova between the Prut river and Black Sea, Russian diplomacy extended the term to the entire territory between Prut and Dniester river. Source: Andrei Brezianu, Historical Dictionary of Republic of Moldova (Lanhaim: The Scarecrov Press,2001), p.20-21.

${ }^{4}$ Ella Akerman, Implications Of Russia's Foreign And Security Policy On Moldova, (Ardeen: Scottish Centre for International Security), access online 30 March 2012:

http://www.google.com/url?sa=t\&rct=j\&q=\&esrc=s\&frm=1\&source=web\&cd=8\&ved=0CGcQFjAH\&url=http\%3A $\% 2 \mathrm{~F} \% 2 \mathrm{Fleader}$.viitorul.org\%2Fpublic\%2F530\%2Fen\%2FImplications_Russia_policy.doc\&ei=8bCZT4njO8mJ6AH b3-zvBg\&usg=AFQjCNHQzuIJCpLKxXv8Lgby9V_IqjstwA\&sig2=X-X76qX2RtCOR9WIgoHH5-g

${ }^{5}$ Ibid.
} 
states. One of that main goals of the Kremlin's policy is to maintain Moldova's "political independence" not only from the Romania's influence but most of all, from becoming a member of the EU. The example of the Russian role within the Chisinau's politics, especially concerning potential Moldova - EU integration, which Moscow categorically opposes, might serve as eyeopener for those who claimed that EU - Russian relations are based on a mature partnership.

Another factor that makes the relations between Moldova and Russia so significant is the fact that the Russian policy toward Pridnestrovian Moldavian Republic mirrors the schematic policy toward other breakaway territories like Abkhazia or South Ossetia. In that sense the Transnistrian case serves as an excellent case study of Russian neo - imperialistic attempts to influence (or blackmail) the former republics of the Soviet Union. Hence, the current study will help to answer the question whether the foreign policy of Moscow towards Moldova is another instance of attempting to regain control and influence over a former Soviet colony, the expression of Russian inability of breaking with the Soviet past, or a "harder" version of Russian "soft power".

There is also another aspect of the Russian policy worth analyzing. Namely, the official attitude of the government in Moscow toward Russians who, after disintegration of Soviet Union, found themselves living in the newly independent states. As Russians constitute almost 10 percent of the population of Moldova (and over 30 percent of Transnistria and Bender) their presence remains an important element of the Russian policy toward Chisinau. Thus the constant involvement of Russia into the politics of Moldova's independent state is often excused as the need to defend the interests of the Russian minority living in Moldovan territory. In the current study the question how in practice the Russian policy influences the coexistence of different ethnic groups in Moldova will be answered. 
It is also necessary to point out what kind of impact the relations between Moscow and Chisinau have on the economic and social situation in Bessarabia. In order to do so, this thesis is going to include not only the description of the different types of trade, political, cooperative, enterprise and custom agreements but it will also scrutinize their short and long - term impacts on the Moldovan society and economy. Moreover, this study will focus on the impact that Russian policy has had on the Moldovan political scene by analyzing economic sanctions, political pressures and the influence of Russian interest groups.

Last but not least, it is worth mentioning that the Republic of Moldova and its relationship with its neighbors seem to be completely omitted by both English and Russian - speaking scholars. In fact, in the English - speaking world, there are only two well-known professors, both from United States who are specializing in the Moldovan studies and are publishing books and articles on Moldovan nation - building, the current political situation and the Soviet - Romanian dispute over Bessarabia after World War I- Charles King and Nicholas Dima. ${ }^{6}$ The author was not able to find any comprehensive study on the Russia-Moldova relationship in the aftermath of Soviet's collapse, either in the Russian or English language.

In order to explain all the issues mentioned above the current paper includes comprehensive analysis of the historical background of the relationship between the two countries. Although this part of the research greatly exceeds the observed period for this thesis, including it is necessary for couple of reasons. First, the modern history of Moldova is strictly related to history of the Russian Empire, since after 1812 Moldovan territory was under Russian rule. More than century of Russian government, which implemented a harsh policy of

\footnotetext{
${ }^{6}$ e.g. Charles King, Post-Soviet Moldova: A Borderland in Transition (Chisinou: Center for Romanian Studies, 1997); Charles King, The Moldovans: Romania, Russia, and the Politics of Culture (Stanford: Hoover Institution Press, 2001); Nicholas Dima, Bessarabia and Bukovina: The Soviet - Romanian Territorial Dispute (New York: Colambia University Press, 1982).
} 
colonialism and russification, resulted in growing antagonism between Russian authorities and the native inhabitants. Moreover, one can notice some similarities between the policy conducted by the Russian Federation and the one that was an attribute of Russian Empire at the beginning of twentieth century, such as a ban on Moldovan wine or import sanctions. Finally, the Soviet authorities, while ruling the Romanian territory of Bessarabia in accordance with RibbentropMolotov accords, in order to maintain its independence from Romania commenced the Moldovan nation - building process. This finally led to the creation of the independent Moldovan state and distinct nation in 1991

The first chapter of this thesis presents the history of the Moldovan territory under the rule of the Russian Empire after 1812. It includes the basic components of Russian policy toward the new province, the description of the russification process and colonization of the region as well as the native inhabitants' response towards it. Later, the main focus of the chapter becomes the interwar and the years from 1941 to 1991 when Moldavia became one of the 15 republics subordinated directly to the government of the Soviet Union. The second chapter is devoted to analyzing the Moldova-Russia relations after the collapse of the Soviet Empire. It begins with the description of the Moldovan civil war in the early 90's and Russian involvement in the conflict. It later takes under the scrutiny the numerous attempts to settle the Transnistrian conflict and the foreign policy strategies of both countries. Finally, the last chapter shows the changes in the Moldovan-Russian co-operation that were brought by XXI century. It presents how the rule of Moldovan communists influenced the relationship between the states as well as how the Moldova's geopolitical position between East and West contributed to the political impasse in the country. 


\section{Chapter I}

\section{Historical Background of Russian-Moldovan relations}

\section{Introduction to the History of the region}

The history of Moldova from its very beginning is strictly connected with the history of the Romanian nation. The Romanian Principality of Moldova, inhabited mostly by DacoRomans, predecessors of the Romanians, came into being between the Carpathian Mountains and the Dniester River in the early fourteenth century and was founded by the Wallachian prince from Maramures. Medieval Moldova covered the so-called Carpathian - Danube - Dniester region, from Transylvania in the west to the Dniester River in the east. It is worth noting that shortly before the emergence of the new state, the area between the Prut and Dniester rivers - the motherland of Moldovans - belonged to the Wallachian dynasty Bessarab, after whom the entire province was named Bessarabia ${ }^{7}$

\footnotetext{
${ }^{7}$ Nicholas Dima, Bessarabia and Bukovina: The Soviet - Romanian Territorial Dispute (New York: Colambia University Press, 1982) p. 10.
} 
Map 1 The Medieval Principality of Moldova ${ }^{8}$

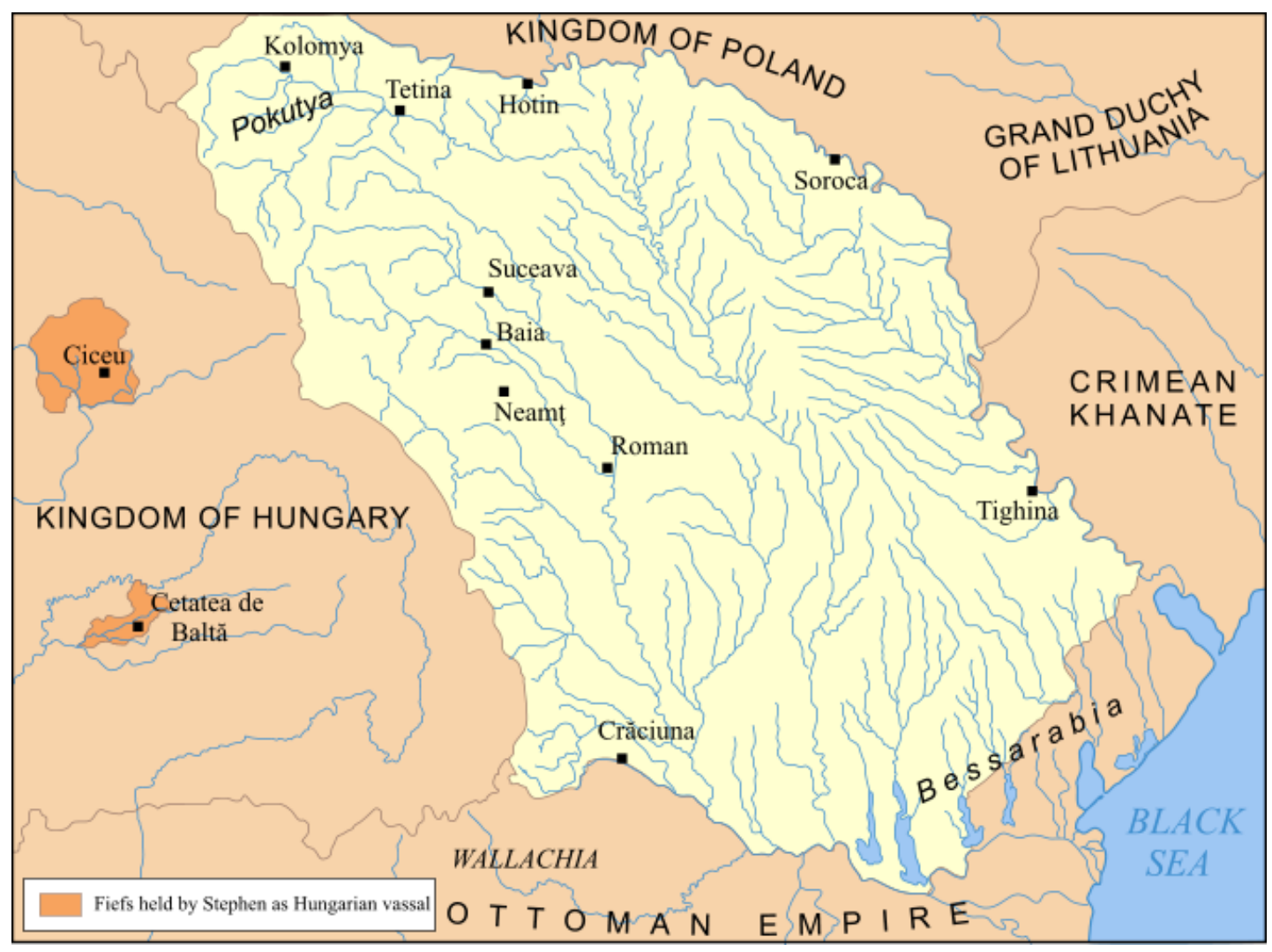

The Romanian inhabitants of the Principality of Moldova migrated to the area, according to Hungarian sources, from the northern parts of Transylvania at the beginning of first millennium. They unified the people already living in the territory and organized the territory into

\footnotetext{
${ }^{8}$ B.a., The Medieval Principality of Moldova, CIA World Factbook, accessed online 21 September 2012, http://www.google.com/imgres?um=1\&hl=pl\&sa=N\&biw=1920\&bih=843\&tbm=isch\&tbnid=7OXWnXprRYgEmM :\&imgrefurl=http://www.answers.com/topic/moldova\&docid=zbOn4D8wi2 fDM\&imgurl=http://content.answcdn.c om/main/content/img/factbook/maps/md-map.gif\&w=328\&h=713\&ei=2FlUNGWHMfQsgbym4DgBA\&zoom=1\&iact=hc\&vpx=1198\&vpy=232\&dur=2227\&hovh=331\&hovw=152\&tx=8 7\&ty $=175 \&$ sig $=112031022142017531206 \&$ page $=2 \&$ tbnh $=123 \&$ tbnw $=56 \&$ start $=56 \&$ ndsp $=68 \& v e d=1 \mathrm{t}: 429, \mathrm{r}: 18, \mathrm{~s}: 5$ 6,i:306
} 
a state ${ }^{9}$. The other ethnic groups that started to settle in the region from the sixth century were mostly Slavs and Tatars, but they cohabited with the locals and they were absorbed fully by them within the first centuries of coexistence. Although by the end of the fourteenth century Moldova had grown in strength and quickly became an important power in southeastern Europe, its geographical location made it vulnerable to the attacks of the Ottoman Turks, Hungarians, and Poles ${ }^{10}$.The young state of Moldova for decades had to fight to defend its independence. Eventually, in 1512 the province agreed to pay tribute to the Ottoman Sultan and thus became a vassal state to the Ottoman Porte, yet it enjoyed relative autonomy within the Empire. The following centuries were marked by continuous struggle among the great European powers at that time: Austria, Turkey, and Russia - over Southeastern Europe ${ }^{11}$. During the seventeenth and eighteenth centuries the Russian Empire begun to expand into southern Ukraine, dangerously drawing near to the Bessarabian territory. Simultaneously, the process of disintegration of the Ottoman Empire resulted in the dismemberment of Moldovan territory. Firstly, in 1774 the northwestern part of principality (Bukovina) was ceded to the Habsburg Empire and then, the rest of historical Moldova between the Prut and Dniester (Bessarabia) was incorporated by Russia ${ }^{12}$.

\footnotetext{
${ }^{9}$ Marcel Mitrasca, Moldova, A Romanian Province under Russian Rule: Diplomatic History from the Archives of the Great Powers (New York: Algora Publishing, 2002), p.18.

${ }^{10}$ The principality of Moldavia lied directly on the north-south trading route linking the Hanseatic states with the Genoese and Byzantine settlements along the Dniester River and the Black Sea. The Principality also stood at the center of the conflict between the Poles, Hungarians and Ottomans after the fifteenth century as often collaborating with foreign invaders as standing together against them. Charles King, The Moldovans: Romania, Russia, and the Politics of Culture (Stanford: Hoover Institution Press, 2001), p.14.

${ }^{11}$ Dima, Bessarabia and Bukovina: The Soviet - Romanian ...,p.11.

${ }^{12}$ Ibid.,p.10.
} 


\section{The First Annexation of Bessarabia and Russian Rule, 1812 - 1918}

At the time of annexation, the Bessarabian territory - 17,350 square miles, included between 240, 000 and 350, 000 people, most of whom were Romanian- speaking Moldovans ${ }^{13}$. Due to the unstable international position of the Empire (the war with France), the region's great distance from the Russian capital and finally the poor condition of the Russian finances, in the first phase of Russian domination, Bessarabia was able to gain a privileged status within the empire. ${ }^{14}$ In the first phase of Russian domination, the unstable international position of Empire, the war going on with France, the territories great distance to Russian capital and finally the poor condition of the Russian finances resulted in granting Bessarabia a privileged status ${ }^{15}$.The Russian government decided to give the region certain autonomy, including the preservation of the Ottoman privileges and the application of traditional Moldovan laws and customs. Nevertheless, knowing the horrible situation in the areas earlier incorporated to Russia, tens of thousands Moldovan families decided to move to the western bank of the Prut River. Moreover, Moldovan boyars did not recognize the Russian incorporation of the area, arguing that the Turks could not cede the right to the Moldovan territory, as it was not a Turkish province but just a vassal of Turkey and that "the Sultan had no right to accept the cession of territory without their consent." 16 Nevertheless, owing to the intention to create an example of how Russia would treat the territories which had belonged to Ottomans, the new acquisition was not subjected to the

\footnotetext{
${ }^{13}$ Historians despute the actual number of inhabitants at the time of annexation: Nistor, Istoria Bessarabiei(Bucharest: Humanitast, 1991), 197.; Popovici Andrei, The political status of Bessarabia (Washington:Randsell, 1931), 80 ; King, The Moldovans: Romania, Russia, and the Politic,p.19.

${ }^{14}$ Mitrasca, Moldova, A Romanian Province under Russian Rule ..., p. 20.

${ }^{15}$ Mitrasca, Moldova, A Romanian Province under Russian Rule..., p. 20.

${ }^{16}$ King, The Moldovans: Romania, Russia, and the Politics..., p.19.
} 
same oppressive measures as other territories of the Russian Empire. ${ }^{17}$ Tsar Alexander I allowed the Bessarabian nobles, led by Gavril Banulescu-Bodoni, to constitute a civil government and under the special rule established in 1818, Moldovans were given wide latitude in the local government, with Moldovan language serving alongside Russian as an official language of the local administration. ${ }^{18}$ Autonomy was also given to the local Orthodox church which maintained independence from the Moscow Patriarchate. Marcel Mitrasca, a scholar of diplomatic history affiliated with Babes Bolyai University, claims that Russia's policy toward Bessarabia was not only the result of the international tensions and domestic problems of the Empire, but mainly the result of Tsar Alexander's tactic to "win over the inhabitants." 19 The Russian Tsar, while giving instructions to the boyars loyal to Empire, said: "The public burdens must be equally distributed: the honesty of the administrative officials must make the inhabitants forget the lack of a regular system of laws, let the inhabitants feel the advantage of the fatherly and liberal administration. Draw the attention of neighboring people to this province by making it happy."20

Yet Moldovans did not enjoy privileged treatment for long as Russian policy soon changed. The death of the Moldovan leader Banulescu-Bodoni in 1821 resulted in the growing assertiveness of the boyars which, in turn, resulted in retracting many of the privileges and rights given in the first years of annexation. ${ }^{21}$ The immediately deteriorating situation of the local nobles and the change for the worse in the economy led to the boyars' insurrection in 1821 . The Bessarabians did not need to wait long for the Russian response. In 1829 the autonomous Province of Moldova became a Russian Gubernia, which meant in practice the end of the special

\footnotetext{
${ }^{17}$ Bruchis, Michael, The Republic of Moldova: From the Collapse of the Soviet Empire to the Restoration of the Russian Empire (New York: Columbia University Press, 1996), p.11.

${ }^{18}$ Nistor, Istoria Besarabiei..., p.228-231.

${ }^{19}$ Mitrasca, Moldova, A Romanian Province under Russian Rule..., p.20.

${ }^{20}$ Quoted in: Robert William Seton-Watson, The history of Roumanians: From Roman Times to the Completion of Unity (Oxford: Veda Publishing House, 1963), p.32.

${ }^{21}$ King, The Moldovans: Romania, Russia, and the Politics..., p.22.
} 
status of the region within the Empire. Meanwhile, the newly crowned Tsar Nicholas I did not approve Alexander's tactic toward newly incorporated lands as he was rather a believer in a policy of fast colonization and russification of new provinces. He wanted an extension of central control over the newly acquired western territories. ${ }^{22}$ In order to do so, in 1829 the old constitution of Bessarabia was replaced by a new one drafted by the governor of New Russia, M. S. Vorontsov. The laws resulted in practice in a steady process of cultural deterioration. It lifted the obligatory usage of the native inhabitants' language in public administration and primary schools. ${ }^{23}$ In time, the Moldovan language was also removed from Orthodox church services and Romanian books, newspapers and periodicals form west of the Prut river were prohibited while the Moldovan ones were not allowed to publish.

A policy of colonization and russification was continued for several decades with the purpose of "increasing the population and weakening the Romanian element in the province. " 24 Although at the beginning of the introduction of the new policy the primary goal of colonization was to bring as many people to the newly acquired territories to better exploit the land, later the Russian authorities realized that this policy was also helping to diminish the Romanian character of the region. Davide Zafi, in his article "Moldovan-Russian Political Relations in Recent History" describes the Empire's policy of colonization by saying "The Russian government had to resort to incentives for a strong immigration in order to take under cultivation the ground abandoned to itself. New comers were foremost Slavs, but not only: Turks (Gagauz), Bulgarians, Germans, French, Poles also settled in the area and added to its already traditional national

\footnotetext{
${ }^{22}$ King, The Moldovans: Romania, Russia, and the Politics..., p.22.

${ }^{23}$ Bruchis, The Republic of Moldova: From the Collapse of the Soviet Empire..., p.12.

${ }^{24}$ Mitrasca, Moldova, A Romanian Province under Russian Rule..., p. 20.
} 
medley." ${ }^{25}$ From the Empire's point of view, this kind of attitude toward newly "liberated" provinces from Turkish infidels was their "Christian" duty. For instance, twentieth century's Russian historiography presents the annexation of Bessarabia as a liberation of the Christian population form the Turks, justified by the brotherhood of religion. ${ }^{26}$

Russian rule over Bessarabia was suddenly disturbed by the western powers who, alarmed by the Russian expansion around the shores of Black Sea, decided to wage a war against the empire. The so-called Crimean War ended with the Peace Treaty of Paris in 1856, which forced the Russian Empire to withdraw from the Southern part of Bessarabia, adjacent to Danube River, and the region was restored to the Moldovan Province. ${ }^{27}$ The Empire, along with other European great powers, agreed to respect the integrity of the Romanian regions and its national administration. The Romanian authorities immediately began the process of Romanization, focusing on reversing the Russian reforms, establishing Romanian schools and publishing houses as well as introducing the Romanian language in public administration. However, the Romanian efforts to bring about the full Romanian integration of the province appeared to very ineffective as ironically the incorporated lands were the very districts where the Romanian population was the least numerous. ${ }^{28}$ Later on though, through the agreement between Hungary, Austria and Russia in 1878 the Russian Empire managed to take back the lost territories. That resulted in the intensification of the russification process: all the publications in native language were suppressed and the policy of altering the demographic situation in the newly-conquered land strengthened. For example, while in the first decade of the annexation the Romanian speakers

\footnotetext{
${ }^{25}$ Davide Zafi, Moldavian-Russian Political Relations in Recent History (Rome: Centro Studi Sulla Storia Dell' Europa Orientale, 2002), access online 12 April 2012: http://www.csseo.org/Papers/MoldovaDZ.pdf

${ }^{26}$ Mitrasca, Moldova, A Romanian Province under Russian Rule, 21.; George F Jewsburry, The Russian annexation of Bessarabia 1777 - 1828. A Study of Imperial Expansion (Boulder : East European Monographs, No. 28, 1977), p.55.

${ }^{27}$ Dima, Bessarabia and Bukovina: The Soviet - Romanian...,p.14.

${ }^{28}$ The region was later incorporated into the Ukrainian soviet Republic and was never recovered by the Moldavian Republic, Seton-Watson, The History of Romanians: From Roman Times..., p.562.
} 
constituted around the $74 \%$ of the population of Bessarabia (990 000) by the end of the century Romanian speakers were only $47.6 \%$ of the entire population $(1,930,000) .{ }^{29}$ The ethnic structure was different in urban and rural areas. While the cities were almost entirely populated by the Russians and Jews $^{30}$ with strong anti- Romanian attitude, it was mainly Moldovans who populated the villages. ${ }^{31}$ This situation was strictly related to the high level of illiteracy among the Romanian-speaking population. Russified institutions did not reach the Moldovan peasants as they all spoke a different language and did not need to learn Russian just for working on rural farms. As a result, by the end of the century only $10.5 \%$ of Moldovan men and $1.7 \%$ Moldovan women could read and write in any language. ${ }^{32}$

As Nicholas Dima pointedly puts it, the nineteenth century's "Russian management of Bessarabia was a disaster." ${ }^{\prime 33}$ The whole province remained highly underdeveloped and the population, especially Moldovans, remained overwhelmingly illiterate. The language of the native inhabitants was almost completely eliminated from public life. ${ }^{34}$ Moreover, the region had the highest mortality rate in Europe - 50 percent higher than in the empire.

Nevertheless, during the entire period of Russian rule, Moldovans did not lose their linguistic and ethnic (not national) identity. All the writers and artists form Bessarabia and Bukovina like Georghr Asachi, Costache Negruzzi or Bogdan Petrieceicu Hesdeu considered themselves to be Romanians and their language to be Romanian, as in their historical homeland

\footnotetext{
${ }^{29}$ The actual percentage of Romanian speakers could have been higher since the 1897 census tended to count all persons with some knowledge of Russian language as "Russians"; King, The Moldovans: Romania, Russia, and the Politics...,p.23.

${ }^{30}$ Over 50, 000 Jews were living in Chisinau in 1897, accounting for nearly half the population.

${ }^{31}$ Mitrasca, Moldova, A Romanian Province under Russian Rule..., p.21.

${ }^{32}$ B.a.,Pervaia vsesoiuznaia perepis' naselenia Rossiskoi imprerii, 1897 g., vol.20: Bessarabskaia gubernia, (S.Petersburg: 1905), p.130.

${ }^{33}$ Dima, Bessarabia and Bukovina: The Soviet - Romanian..., p.16.

${ }^{34}$ Popovici, The political status of... , 96-109.
} 
of ancient Dacia. ${ }^{35}$ For all the prominent Moldovan figures as well as for Romanian authorities, the unification of the old Romanian provinces was the main goal at that time. Even some of the Russian administrators acknowledged this possibility, seeing how difficult it was to integrate the native inhabitants with the new-comers and within the Russian administration. For instance, the famous General A. N. Kuropatkin wrote in his work published in 1910 that "the population of Bessarabia lived in isolation and aloof form Russians" and that in the future the unification of Moldovans with the Romania might be inevitable. ${ }^{36}$ On the other hand, the Russian administration at that time did not argue that Romanians and Moldovans formed different nations (unlike during the Soviet administration when the theory of Moldovans forming a nation distinct form the Romanian one was a core principle). Although the last thing Russians wanted was the unification of the Romanian nation, their main concern was to extinguish any manifestations of non- Russian nationalism and to create a sense of loyalty to the Empire. ${ }^{37}$ In the official documents, the term Moldovans was used only as an historical name of the population of Bessarabia, not to define Bessarabians as separate nation from Romania.

Yet the national and ethnic self-consciousness among Moldovans was already awakened. The first stimulus for the national movement was already the Crimean War of 1853-1856 as it provided an excellent opportunity to liberate Bessarabia form the Russian occupiers. Later, the Russian revolution of 1905 and the outburst of indignation in the country forced Tsar Nicholas to repeal some legislation against ethnic minorities. ${ }^{38}$ Publishing newspapers and periodicals in native language was again allowed. Using this opportunity, young Bessarabian intellectuals influenced by the social radicalism in the whole Empire, together with a few Moldovan nobles,

\footnotetext{
${ }^{35}$ Bruchis, The Republic of Moldova: From the Collapse of the Soviet Empire..., p.12.

${ }^{36}$ Aleksey Kuropatkin, Zadechi Russkoy Armii, Vol. 2, (St. Petersburg, 1910), 338, Cited by Dima, Bessarabia and Bukovina: The Soviet - Romanian ..., p.16.

${ }^{37} \mathrm{King}$, The Moldovans: Romania, Russia, and the Politics..., p.26.

${ }^{38}$ Bruchis, The Republic of Moldova: From the Collapse of the Soviet Empire..., p.14.
} 
founded Moldovan newspaper called Bessarabia. The publishers' main goals were to spread the message of national awakening to the Moldovan peasants, to call for land reform and unification with Romania, as well as to promote the idea of the introduction of the Romanian language in the schools and public administration. ${ }^{39}$ Besides the emergence of a pan-Romanian nationalist movement, other Moldovan political groups appeared at that time. For instance, the group involved the publication of a second Moldovan newspaper, Moldovanul, gathered mostly the Moldovan nobles who, although they called for economic emancipation of the region, stayed loyal to the Russian authorities. ${ }^{40}$ The most active representative of this group and at the same time the main editor of Moldovanul, Gheorghe Madan, would become the chief propagator of Moldovian language as distinct from Romanian. Finally, there were also groups opposed to the Moldovan nationalists like the League of True Russians or Union of Russian People which gathered mostly non-Moldovan inhabitants.

The turbulence of the First World War, especially the October revolution of 1917 allowed the nationalists to implement all of their demands. The newly created Moldovan National Party openly requested from the Russian authorities in Chisinau introduction of the principles of freedom of speech, press, assembly, and religion. ${ }^{41}$ Not waiting for the official response, Moldovan soldiers along with peasants and workers organized the Sfatul Tarii (the State Council) and on December 2 1917, declared Bessarabia an autonomous republic. ${ }^{42}$ The proclamation of the Sfatul Tarii stated: "from now on Bessarabia declares itself the Moldovan Democratic Republic, which will enter the make-up of the Russian Democratic Federative Republic as participant with

\footnotetext{
${ }^{39}$ King, The Moldovans: Romania, Russia, and the Politics..., p.29.

${ }^{40}$ Ibid.

${ }^{41}$ Ibid., p.30.

${ }^{42}$ Dima, Bessarabia and Bukovina: The Soviet - Romanian ...,p.17.
} 
equal rights. ${ }^{, 43}$ A month later, seeing the lack of response from the Russian side, nationalists took the opportunity and declared Moldova an independent state. However, the threat of Ukrainian intervention as well as Russian military action forced some of the districts to call for Romanian help which in effect resulted, on March 27 1918, in the proclamation of the unification of the Democratic Republic of Moldova with Romania.

\section{Soviet Policies on the Romanian Border. Creation of MASSR}

It is not difficult to picture the Russian reaction to such a course of the events. For Soviet authorities, the 1918 Union between Bessarabia and Romania was a military, violent annexation of Russian territory by taking advantage of the situation in Russia at the end of the First World War. Not surprisingly, Romanians saw it from a completely different perspective. Romanian historiography places the event in the context of the long expected union of the historically Romanian provinces into one state, Greater Romania. ${ }^{44}$ Yet, the newly created Soviet Union did not want to let Bessarabia go and soon commenced an extensive propaganda in order to get back the lost territory as soon as possible. For instance, already in 1918 the first propaganda brochures read that "Romania had about as much right to Bessarabia as, let us say, Russia had to Ireland, or to some provinces belonging to France, Italy , or Japan." ${ }^{45}$ On the international scene, the Soviets liked to present the annexation as an unlawful action as Bessarabia did not belong to Romania in a period preceding Russian rule but to Turkey and therefore there was no possibility for re-

\footnotetext{
${ }^{43}$ Bruchis, The Republic of Moldova: From the Collapse of the Soviet Empire..., p.15.

${ }^{44}$ Mitrasca, Moldova, A Romanian Province under Russian Rule..., p. 27.

${ }^{45}$ Grigore Nadris, Bessarabia and Bukovina (New York: Societatea Pentru Cultua,, 1968), p.111.
} 
unification. ${ }^{46}$ Nicholas Dima, a specialist on Romanian history form Columbia University, pointedly comments on this argument by saying that this line of argument automatically eliminated Russian right to Bessarabia because USSR, like Romania, did not exist at that time either. $^{47}$

The Russian rule over Bessarabia left the region in very poor condition - the infrastructure and economic backwardness was unspeakable. Little more than 90 miles of paved roads was built during the Russian government, which additionally became inaccessible during the heavy rain. ${ }^{48}$ Moreover, Russian authorities had built " 657 miles of railroad in the Gubernia before 1917, but since the railways were designed for strategic rather than economic purposes, they connected Bessarabian cities with Russia and Ukraine but not with each other; the primitive state of the rolling stock, as well as Russian broad-gauge track, also proved to be major problems." ${ }^{, 49}$ Trade with neighboring countries also declined significantly from the moment of reunion with Romania. Moldovan wine, one of the main export products, was banned by the Soviets while Poland, trying to maintain good relations with Russia, tore up the trade agreements with main Moldovan manufacturers. As we will see in the next chapters of this study, such economic sabotage was not only characteristic of Soviet policy toward border territories, but will also be the strategy of the contemporary Russian government.

However, the wretched economic state of Bessarabia did not frighten away the Soviets. When the Russian efforts to prevent the ratification of Peace Treaty by the great European powers failed, Russians came up with "plan B". ${ }^{50}$ The new Soviet strategy consisted of spreading

\footnotetext{
${ }^{46}$ Kristof Ladis, Russian Colonialism and Bessarabia: A Confrontation of Culture (Washington D.C.: Department Of State - Office Of External Research, 1974), p.21.

${ }^{47}$ Dima, Bessarabia and Bukovina: The Soviet - Romanian ..., p.22.

${ }^{48}$ Clark Upson, Bessarabia: Russia and Roumania ..., p.18.

${ }^{49}$ King, The Moldovans: Romania, Russia, and the Politics..., p.42.

${ }^{50}$ By the Peace Treaty the author means the Paris Peace conference of March 9, 1920, where the western powers consented to the reunion of Bessarabia with Romania.
} 
communist propaganda across the borders of Romanian Moldova and thus find Bessarabian supporters of reunion with Russia. In order to do so, the Soviet Union commenced the publishing of a communist newspaper in Romanian Plugarul Rosu (The Red Plowman), used to spread Marxist propaganda. Additionally, Bolshevik agents were very active in the Moldovan countryside; Soviet planes dropped pamphlets everywhere when occasionally shots were exchanged between Russian and Romanian solders. ${ }^{51}$ Part of the above-mentioned plan was also the creation of Obshchestvo Bessarabtsev (the Bessarabia Association) in Moscow which was responsible for the agitating for Moldova's reunion with the Soviets on the international scene, especially in France and Germany. This intensive Soviet agitation resulted in the outburst of three anti-capitalist risings in Bessarabian towns: Hotin and Bender in 1919 and Tatar Bunar in 1924. The brutal suppression of the last one became an excellent opportunity for the Soviets. ${ }^{52}$ In September 1924, one of the Plugarul Rosu's issues published the letter from Moldoan peasants who asked for creation of an autonomous communist republic. ${ }^{53}$ Meanwhile Moscow started recruiting the leadership for a future communist state. As a result, on October 12 1924, the Soviet Union announced the establishment of Moldavian Autonomous Oblast on land east of the Dniester river in the Ukrainian Soviet Socialist Republic with the capital in Balta, in present-day Ukraine. $^{54}$ Seven months later, the Oblast was upgraded to the Moldavian Autonomous Soviet Socialist Republic (Moldavian ASSR, also called Transnistria), although its population was only $30 \%$ ethnic Moldovans while Ukrainians made up over $49 \%$ of all inhabitants. ${ }^{55}$ Its surface area was only 8,300 square kilometers. ${ }^{56}$

\footnotetext{
${ }^{51}$ King, The Moldovans: Romania, Russia, and the Politics..., p.51.

${ }^{52} \mathrm{It}$ is worth mentioning that organizers of above-mentioned risings who postulated the rights of Moldavian inhabitants were mostly non-Moldovian communists.

${ }^{53}$ Dima, Bessarabia and Bukovina: The Soviet - Romanian ..., p.22.

${ }^{54}$ Soviet renamed the region Moldavia and native population Moldavians.

${ }^{55}$ Helen Fedor ed.. Belarus and Moldova : Country Studies (Washington, D.C. : Library of Congress, 1995$)$, p.106.

${ }^{56}$ Dima, Bessarabia and Bukovina: The Soviet - Romanian ..., p.23.
} 
The chief aim of Moscow's decisions was not the creation of the republic itself but rather to induce Moldovans living in Romania to agitate for reunification with the Soviet Union and put the pressure on Romania in negotiations over Moldovan's future. ${ }^{57}$ For instance, Nicholas Dima argues that this kind of strategy was used by the Russians in 1920s in the cases of the KareloFinish Socialist Republic, in the Tadzhik Republic in Central Asia Buriat-Mongol Autonomous Republic: Russians worked through communist agitation toward incorporation into certain territory into the Soviet empire. ${ }^{58}$ Immediately after the creation of MASSR, which later was also called Transnistria, the Soviets begun to speak of Moldovans as if they were another nation, different form Romanians. That was also the part of the Russians' policy on border regions. They used the propaganda of national liberation to draw those lands away from "the capitalist states" like Romania or Finland. ${ }^{59}$ But the data from the first years following the emergence of MASSR in an eloquent testimony that the republic was the artificially created administrative-political formation aimed at serving as a permanent reminder of Russia's firm stand on Bessarabia. ${ }^{60}$ For instance, the party regional committee, the chief authority at that moment, consisted mainly of non-Moldovan Bessarabian activists, while in the Moldavian Communist Party at the end of 1924, there were only $6.3 \%$ of Moldovans representatives. ${ }^{61}$

In the 1920s the notion that Moldovans constituted a separate ethno - national group was the Bolsheviks' crucial argument against Romanian possession of Bessarabia. Therefore, the first years after the birth of Transnistria were marked by Moldovan nation-building. The so-called "process of "Moldovianization" was mainly focused on creation of a distinct Moldovan literary language and education of the peasants and thus bringing them into the structures of "genuinely

\footnotetext{
${ }^{57}$ Ronald J. Hill, Soviet Political Elite. The Case of Tiraspol (New York: St. Martin Press, 1977), p.11.

${ }^{58}$ Dima, Bessarabia and Bukovina: The Soviet - Romanian..., p.23.

${ }^{59}$ King, The Moldovans: Romania, Russia, and the Politics..., p.51.

${ }^{60}$ Bruchis,The Republic of Moldova: From the Collapse of the Soviet Empire..., p.20.

${ }^{61}$ Documenty vneshnei politiki S.S.S.R. (Moscow, 1963), vol. 7, p.181-182.
} 
Moldovan republic" and more importantly, into the communist party. ${ }^{62}$ For example, in 1925 the first dictionary of the Moldovan language was published using the Cyrillic alphabet instead of Latin script just in order to make the language less similar to Romanian. On top of that, the Soviets introduced preferential hiring and promotion for the benefit of non-Russian nationalities, began the program of building Moldovan schools and promoting the use of indigenous languages in education, as well as commenced the project of lowering the illiteracy level among Moldovan woman.

Meanwhile, during the entire interwar period communist activists as well as Soviet agents in Romania were involved in a range of Soviet agitprop activities aimed at organizing the revolution in Romanian Bessarabia. However it did not produce the expected results. The main reason why the "export of revolution" failed was that although Moldovan peasants "were hardly enthusiastic about the presence of Romanian gendarmes and soldiers", they were even less supportive of Soviet calls for the Collectivization of land and expropriation of peasant property. ${ }^{63}$ Not without significance was the legacy of Russian rule over Bessarabia in the previous century. Moldovans remembered very well how the Russian empire's authorities harshly treated the native inhabitants and therefore preferred to stay within the newly created Greater Romania than to risk returning to Russian government. A similar process can be seen in the more recent history of relations between those two nations after the collapse of Soviet Union which will be described in the next chapter.

In the given situation, the Soviet Union was forced to abandon its aggressive international policy and to temporarily accept Romanian possession of the province. Between 1928 and 1939 Romania and the USSR signed a series of bilateral treaties that were concluded

\footnotetext{
${ }^{62}$ King, The Moldovans: Romania, Russia, and the Politics..., p.70.

${ }^{63}$ King, The Moldovans: Romania, Russia, and the Politics..., p.51.
} 
with the exchange of ambassadors and the establishing of diplomatic relations in 1934. Moreover, during the same year the USSR asked to be a member of the League of Nations and Romania, an important state in the organization, was a great supporter of it. ${ }^{64}$ Thus the Soviet Union became constrained to obey the international legal provisions created by the League, which included the territorial integrity of the member states. ${ }^{65}$ The dispute over the status of Bessarabia became loud again with the signing by the Soviets of the Ribbentrop - Molotov treaty which in the secret protocol indicated the Soviet sphere of influence over the entire eastern Europe, including the territory of Romanian Bessarabia.

Simultaneously in Tansnistria the Soviet nation-building policy underwent significant changes. In the years 1937 and 1938 the Stalinist purges and the massive ethnic cleansing continued. This sudden shift away from the policy of nation-building was, according to the theory of Terry Martin the result of the Soviet xenophobia. However, by Soviet xenophobia Martin does not mean the traditional reluctance toward foreigners but "the exaggerated Soviet fear of foreign influence and foreign contamination." ${ }^{, 66}$ The Soviet national consolidation projects throughout the 1920's gave a certain freedoms and rights to the Soviet nationalities what, in torn, awakened the Russian's suspicious of foreign capitalist countries influencing the Soviet regions.

In effect the party-state activists of Autonomous Republic together with leading cadres of culture and literature ended up being repressed. ${ }^{67}$ As replacements Russian authorities chose young communist activists from Ukraine and MASSR and ambitious workers who were completely unfamiliar with the culture and national identity of Moldovans and in their majority

\footnotetext{
${ }^{64}$ Dima, Bessarabia and Bukovina: The Soviet - Romanian..., p.25.

${ }^{65}$ Francis PaulWalters, A History of the League of Nations (London:Oxford University Press, 1952), vol. I, article 10, p.48.

${ }^{66}$ Terry Martin, "The Origins of Ethnic Cleansing” The Journal of Modern History, (Vol. 70, No. 4 December 1998), p.829.

${ }^{67}$ Bruchis, The Republic of Moldova: From the Collapse of the Soviet Empire..., p.21.
} 
did not even know the Moldovan language. The aggressive nationalist policy practiced on the autochthons resulted in "severing the Moldovans form the east bank of the Dniester river" from their own culture and transforming their language into "a Moldovan-Russian-Ukrainian jargon". 68 The changes in Soviet policy included also the sudden decision of using the Latin alphabet in literary Moldovan. The source of the "latinization decision" was rooted in the unbending Soviet attempts to recapture Romanian Bessarabia. The Soviets this time wanted to emphasize "the common bond between the language of the Moldovans of the MASSR and of the Moldovans on the other side of the Dniestr" and to "increase the revolutionary influence of the Soviet Socialist Moldova on the other side. ${ }^{.69}$

This Soviet policy directed at recapturing Bessarabia, on the domestic as well as international front, soon brought an expected effect. Alongside with the outbreak of war, the German and Russian governments automatically put into effect agreements included in the Ribbentrop-Molotov Pact in which Hitler acknowledged Russian claims to Bessarabia. On June, 1940 Stalin issued an ultimatum to the Romanian government demanding the immediate cession of the region, including the northern portion of province of Bukovina. ${ }^{70}$ Taking under consideration the fate of Poland, Romania reluctantly agreed to withdraw, but by no means accept this loss of territory. In October 1940, the German troops entered Romania and several months later Romania became an German ally and when the Soviet-German war broke out on June 22, 1941, the Romanian army immediately marched into occupied Bessarabia. ${ }^{71}$ In a month Romanian and German troops managed to free Bessarabia as well as Soviet Transnistria and then reintegrate them into Romania. Yet Romanian rule, marked by the brutal anti-Jewish policy, did

\footnotetext{
${ }^{68}$ Bruchis, The Republic of Moldova: From the Collapse of the Soviet Empire..., p.22.

${ }^{69}$ B.a., "10 ani de construire socialista", Soviet Political Elite, The Case-RASSM, vol.18, no.21, p.18.

${ }^{70}$ King, The Moldovans: Romania, Russia, and the Politics..., p.91.

${ }^{71}$ Dima, Bessarabia and Bukovina: The Soviet - Romanian..., p.36.
} 
not last long In 1944 the course of war changed in favor of the Allied Powers, Transnistria again came under Soviet control, and the Red Army advanced westward into the territory of Romanian Bessarabia and southern Bukovina. ${ }^{72}$ Soon after the Russians demanded from the Romanian government the restoration of the 1940 boundary, promising in exchange not to interfere in

internal Romanian domestic affairs. ${ }^{73}$ Bessarabia's doom was sealed as the western powers during the 1944 conferences eventually decided to give the Soviets a free hand in eastern Europe. A 1947 treaty formally returned Bessarabia, northern Bukovina, and Transnistria to Soviet Union.

\section{Soviet policy vs. Native inhabitants. The Moldovan Soviet Socialist Republic (MSSR), 1944-1989}

The new communist republic that emerged from Russian annexation was "both more and less than historic Bessarabia." 74 The newly created region was composed of six administrative units of former Romanian Bessarabia and six eastern raions of Transnistria. ${ }^{75}$ According to the demographic structure of the newly recaptured land, the Russians decided to incorporate into the Ukrainian SSR the part of Transnistria with the Ukrainian majority as well as part of the counties

\footnotetext{
${ }^{72}$ King, The Moldovans: Romania, Russia, and the Politics..., p.94.

${ }^{73}$ Dima, Bessarabia and Bukovina: The Soviet - Romanian ..., p.37.

${ }^{74}$ King, The Moldovans: Romania, Russia, and the Politics..., p. 94.

${ }^{75}$ As the date of the emergence of MASSR Soviet documents (fallowed by international sources) posited the annexation on August 2, 1940 not the one in 1944.
} 
of Hotin in northern Bessarabia and Akkerman, and Ismail in southern Bessarabia. ${ }^{76}$ The Transnistria areas included in the MSSR, on the other hand, were those with the largest group of native Moldovans as they composed almost half of the entire population. However, Charles King claims that there was an even more important rationale than the demographic in the administrative changes undertaken by the Soviets. Namely, "the inclusion of Bessarabia's Danube and Black Sea frontage in the Ukrainian SSR placed these strategic assets in the hands of a reliable Soviet Republic rather than leaving them under the control of the newly created entity and the potential object of Romanian irredentism."77 Regardless of the Soviet goals, the new Moldovan Soviet republic was second smallest after Armenian SSR with the population 2.4 million and 33700 square kilometers surface.

\footnotetext{
${ }^{76}$ Alexander Surilov ed., Gosudarstvenno - pravovye akty Moldavskoi SSR (Chisinau: Cartea Moldovenesca, 1963), p.149-152.

${ }^{77}$ King, The Moldovans: Romania, Russia, and the Politics..., p.95.
} 
Map 2. The Moldovan Soviet Socialist Republic 1944-1991 ${ }^{78}$

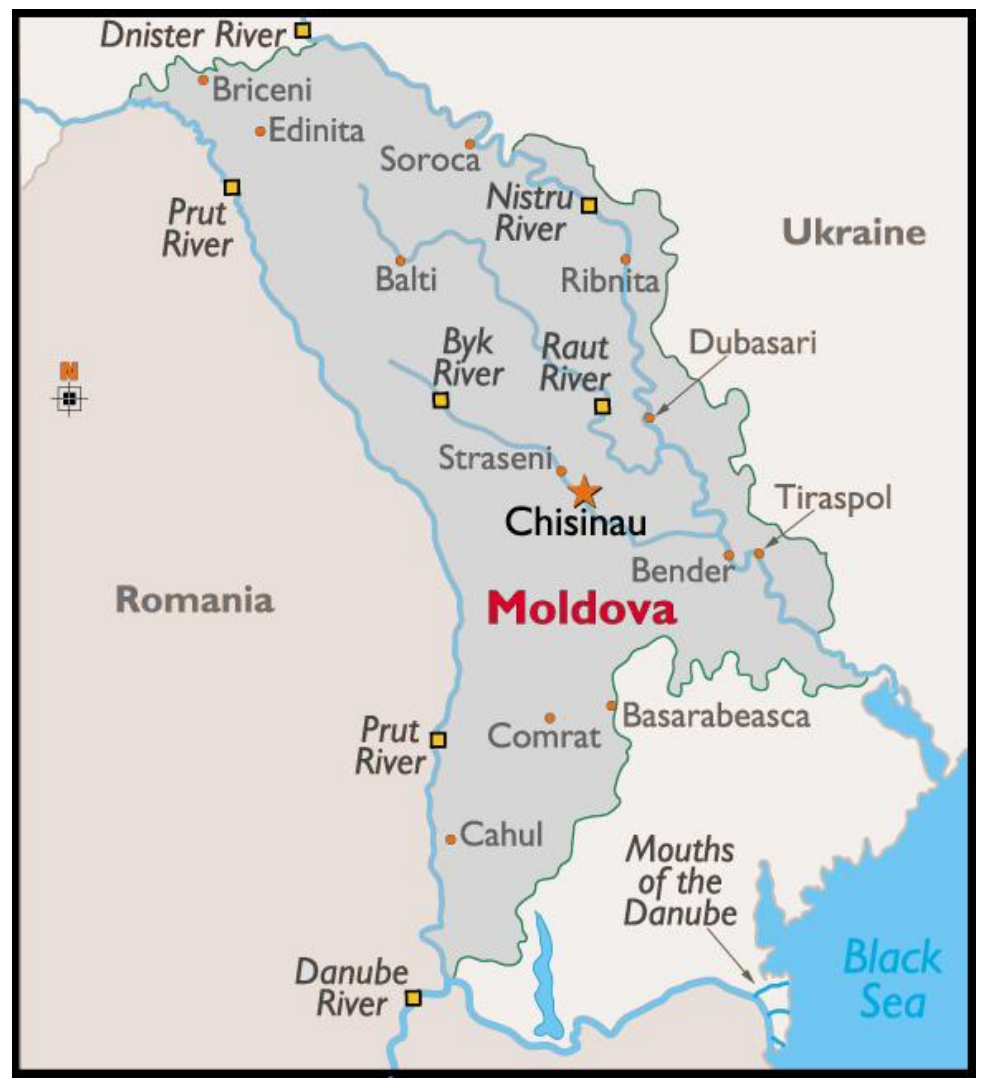

With the restoration of Russian government in Bessarabia, the Stalin regimes policy was to russify the population as soon as possible and annihilate any remaining ties between the MSSR inhabitants and Romania. ${ }^{79}$ Leonid Brezhnev, first secretary of the MSSR Communist Party, at the beginning of his term noted that "these remote raions lying along the Dniester had to break through to socialism by the shortest possible path." ${ }^{\prime 80}$ This declaration meant in practice the implementation of total collectivization of agriculture in the first post-war years. The government's policies of requisitioning huge supplies of agriculture products despite poor

\footnotetext{
${ }^{78}$ B.a., The Moldovan Soviet Socialist Republic 1944-1991, vbmap.org, accessed online 12 April 2012, http://www.vbmap.org/europe-maps-9/map-moldova-396/

${ }^{79}$ Fedor ed.. Belarus and Moldova : Country..., p.107.

${ }^{80}$ Leonid Il'ich Brezhnev, Vospominaniia (Moscow: Izdatel'stvo politicheskoi literatury, 1983), p.141.
} 
harvests - induced a famine following the catastrophic drought of $1945-47 .{ }^{81}$ There are some evidence that the famine of 1946 - 50 was not the tragic consequence of cumulating factors collectivization, drought and mass deportation - but rather the purposeful operation of the Soviets aimed at rural Moldovans ill-disposed toward new regime. ${ }^{82}$ But the tragic outcome of collectivization did not stop the Soviets away from conducting further repressive polices against Moldovan peasants. During the years 1947-51 the Soviets also carried out a massive deportation campaign which in all resulted in the deportation of 16,000 Moldovans peasant families. For example, in only two days, July 6-7, 1949 over 11,000 Bessarabian families were targeted for deportation to Kurgan, Tiumen, Irkutsk, and other destinations in Siberia and Kazakhstan in the plan "Operation South". 83

Along with collectivization the Soviets decided to change the structure of the MSSR Communist Party in order to create a support group for themselves among native people. Hence, in 1949 over $50 \%$ of newly selected members of the Party were Moldovans. Thus, the Soviets created the illusion that Moldovans themselves had the right to decide on the fate of republic through the Soviet institution. The years right after the annexation were also marked by Soviet striving to impose the "Moldovan-Russian-Ukrainian jargon", used already on the left bank of the Dniester, upon the Bessarabian Moldovans. ${ }^{84}$ Immediately after taking over Bessarabia, Soviet authorities ordered the publication of all the school textbooks, newspapers and works of fiction in this jargon, using the Cyrillic alphabet. However this decision encountered the significant opposition from Bessarabian society, especially prominent Moldovan writers. As most of those writers were loyal communist activists agitating during the war in favor of the Soviets, the latter

\footnotetext{
${ }^{81}$ Fedor, Belarus and Moldova : Country..., p.107.

${ }^{82}$ Aleksei Taranetal, Golod v Moldove, 1946-1947: Sbornik Dokumentov (Chisinau: Stiinta, 1993), p.9.

${ }^{83}$ Charles King, Post-Soviet Moldova: A Borderland in Transition (Stanford: Center for Romanian Studies, 1997), p.63.

${ }^{84}$ Bruchis, The Republic of Moldova: From the Collapse of the Soviet Empire..., p.24.
} 
decided to step back from the harsh language policy. Not for long, however. During the entire 1950s the Soviets continued the constant reduction of the Moldovan language from public administration as well as the systematic transformation of the latter's conversational form into Moldovan-Russian jargon. ${ }^{85}$

Stalin's death in 1953 and the Khrushchev's policy surprisingly did not weaken the sovietisation process in Moldovan republic. The domination of the Russian language in the public sphere, the massive Slavic migration into the Moldovan territory as well as the constant deportation of the native inhabitants to Central Asia and Siberia continued and in the long - term resulted in the further "demoldovianization" of the republic. It was especially visible in the demographic data of that time. For example, Moldovan constituted some 68 percent of the population in 1941, but only 63.9 percent by the 1978 census. Ukrainians, on the other hand, rose from 11.1 percent in 1941 to 13.8 percent in 1989. The Russians population doubled within those years. ${ }^{86}$ The natural consequence of those demographic changes as well as the Moscow's desire to widen the control over Soviet territories was the disproportionate presence of Slavs in every sphere of public life. ${ }^{87}$ Moreover, the Communist Party that was supposed to represent the entire population of the republic was dominated by Ukrainians and Russians while Moldovans were holding the least important offices. Similar domination appeared in the cultural life as well. The cultural and scientific urban centers were developed by non-Moldovans, especially Russians, and thus the high culture of the republic quickly became fully russified. The culture of Moldovans was developed only in the rural area, the only area where Moldovans reminded a majority. Therefore the Bessarabian culture was limited to the folklore and the folk art and "for many years

\footnotetext{
${ }^{85}$ Bruchis, The Republic of Moldova: From the Collapse of the Soviet Empire..., p.24.

${ }^{86}$ King, The Moldovans: Romania, Russia, and the Politics..., p.101.

${ }^{87}$ Dima, Bessarabia and Bukovina: The Soviet - Romanian ..., p.117.
} 
shared nothing in common with the superimposed [Soviet] culture." ${ }^{88}$ A Similar situation was noted in academia. In over 60 research centers all over Moldavia that employed altogether over 6 , 000 scientific workers only around 25 percent of them were ethnic Moldovans. ${ }^{89}$ Additionally, all the publications and the newspapers were either published by non-Moldovans or subjected to the Soviet editing.

This situation raised remarkable resentment among the native population that was tired of the constant indoctrination and control. On one hand, Bessarabians, who were struggling to preserve their own language and culture for almost 30 years after the Second World War, started to understand that they cannot really expect any shift of Russian policy. Thus, tired of struggling with the Russian authorities, they were ready to give up their own national identity and to became well-integrated subjects of the Soviet system. But, on the other hand, the tragic condition of the Union's economy, uncertain political situation and the common atmosphere of resignation gave the oppressed nation one more reason to fight for its rights. As Nicholas Dima rightly puts it, "In their desperation, some of the more advanced Soviet nationalities, motivated by the concern for survival, begun to reassert their national rights without any fear." 90

The beginning of 1980's was marked by the Moldovan national awakening, as the new generation of Moldovan activists and intellectuals became very active on the political scene. During that time the language question became central to the national movement. Moldovan politicians demanded the introduction of the Moldovan language in the public institutions, including schools. Bessarabian cultural and academic elites were also pressing for the transition to the Latin alphabet and the recognition of the a Moldovan-Romanian languages' union. But the Moldovan leaders radically shifted their demands when in September 1983 the enormous

\footnotetext{
${ }^{88}$ Ibid.

${ }^{89}$ Dima, Bessarabia and Bukovina: The Soviet - Romanian ..., p.118.

${ }^{90}$ Dima, Bessarabia and Bukovina: The Soviet-Romanian..., p.133.
} 
environmental disaster in Lvov took place. More that a billion gallons of salts form fertilizers spilled into the Dniest river and contaminated the source of water for every major Moldovan city and killed wildlife along the river. ${ }^{91}$ The Moldovan activists in the Communist Party immediately demanded an investigation and raised accusations against the conservative communist leaders whom they held responsible for the incident.

The repercussions of the Dniestr disaster coincided with a radical change of the Soviet policy - the political movement of pierestroika and glasnost' founded by the First Secretary of the Communist Party, Michail Gorbachev. The policy of "openness" and economic reconstruction commenced the transformation of the rusty Soviet system and inspired the major changes in the politics of the Union's republics. ${ }^{92}$ This movement, in turn, inspired tens of thousands of native Bessarabians to express their discontent with the local authorities and commence the extensive public debate regarding the national identity of Moldovans. Thus, from denouncing the ecological disaster of the Dniestr, "Moldovans moved toward claiming their cultural rights, and then, toward demanding the creation of the independent Moldovan government." ${ }^{93}$

However, the First Secretary of the Moldovan Party, Semion Grossu, successfully managed to slow down the pace of political transformations, as he was not interested in reforms that would remove the old, Stalinist-style cadre from the office. Yet, assistance for the Moldovan national movement came surprisingly from Moscow. During the $19^{\text {th }}$ conference of Soviet Communists Gorbachev announced the new program of the revolutionary reforms that included "the multicandidate elections, the retreat from the party's dominance in the economy, and the greater sensitivity to the nationalities question." ${ }^{.94}$ The Soviet policy shift was further confirmed

\footnotetext{
${ }^{91}$ Dima, Bessarabia and Bukovina: The Soviet-Romanian ..., p.118.

${ }^{92}$ King, The Moldovans: Romania, Russia, and the Politics..., p.121.

${ }^{93}$ Dima, Bessarabia and Bukovina: The Soviet - Romanian ..., p.134.

${ }^{94}$ King, The Moldovans: Romania, Russia, and the Politics..., p.122.
} 
in the articles published by the Moldovan Konsomol Congres that set up the introduction of the new language and social reforms. This, in turn, gave an impulse for to establishment of the Moldovan quasi- political organizations with the most prominent among them being: Moldovan Movement in Support of Reconstructing and the Alexei Mateevici Literary-Musical Club. ${ }^{95}$ The founding fathers of those organizations, Bessarabian journalists and political activists, stressed the need to change the status of the Moldovan language and they demanded the recognition of the identity of Moldovans. Most importantly however, they called for the transformation of Soviet Union into a federation of independent states, which can be seen as the first step toward the Moldovan sovereignty. ${ }^{96}$ After officially announcing those demands to the Soviet authorities, Moldovan organizations held in Chisinau massive public demonstrations in support for the Moldovan national movement. Later, in the mid-1989 the meeting of the political activists of all Moldovan organizations took place. They agreed upon the foundation of the Moldovan Popular Front - the first Moldovan National Party. ${ }^{97}$ Under the pressure from both, Gorbachev's government in Moscow and the Moldovan nationalists, Grossu eventually agreed upon legalizing the Moldovan party. "It was the end of the communist monopoly of power" and the beginning of the Moldovan path toward the independence from the Soviet state. ${ }^{98}$

The almost two centuries of the harsh policy of russification influenced the Moldovan's perception of the Russian authorities. The suppression of every aspect of the Moldovan social life and the radical shift in 1937 away from the nation-building policy that was started after the First World War significantly strengthened the local population's reluctance towards the Soviets. The native inhabitants of one of the best integrated republics into the Soviet system suddenly started

\footnotetext{
${ }^{95}$ King, The Moldovans: Romania, Russia, and the Politics..., p. 123.

${ }^{96}$ King, Post-Soviet Moldova: A Borderland in Transition ..., p.63.

${ }^{97}$ Dan Ionescu, Soviet Moldova: A breakthrough in the Alphabet Issue (Chisinau: RFE Research, 15 March 1989), p.4.

${ }^{98}$ Dima, Bessarabia and Bukovina: The Soviet - Romanian , p.145.
} 
to look for the answers regarding their national identity. Taking advantage of the crisis in the Soviet Union in the 1980's, Moldovans decided to take an active part in the political life of their motherland. The reconstruction period brought the first divisions of the Soviet society between the advocates of the perestroika- Moldovans, and its adversaries- non-Moldovans, mostly Russians and Ukrainians. Thus, Bessarabians stopped viewing the interest pursued by the Soviet Union as their own and started to look for political assistance in neighboring Romania and Western European countries. As Davide Zaffi rightly puts it, "One seems justified in asserting that the way Moldovans acted or reacted both in the international context and in internal affairs [after the proclamation of independence] was determined or largely influenced by the attitude they successively took towards Russia." $" 99$

\footnotetext{
${ }^{99}$ Davide Zaffi, Moldavian-Russian Political Relations in Recent History ( Levico Centro: Centro Studi Sulla Storia Dell'Europa Orientale, 2001), p.21.
} 


\title{
Chapter II
}

\section{The Establishment of the Political and Economic}

\author{
Co-operation. 1989 - 1999
}

\section{On the Path to Independence. 1989-1991}

Although the government of Moldova Did not declare the full independence before August 1991, it began the path to independence from the USSR already two years earlier. As Charles King puts it, one could call the years between 1989 and 1991 "the crusade for rectifying and appropriating the Moldovans' genuine national identity after a half century of Soviet rule." ${ }^{100}$ Accordingly on August 31, 1989, the MSSR Supreme Soviet adopted the „Language Act" that declared Moldovan the state language of the republic, it "mandated the transition to Latin alphabet, implicitly recognized the unity of the Moldovan and Romanian languages, and set out the broad program for extending the use of Moldovan in government, education, and the national economy. “101 In this way the Soviet Republic of Moldova became the first of the Union's entities that established the language of native inhabitants as the first official language. According to Daria Fane, the American political scientist, this new legislation proved to be a turning point in republic's politics and caused the rise of nationalism among both Moldovans and those ethnic

\footnotetext{
${ }^{100}$ King, The Moldovans. Romania..., p.126.

${ }^{101}$ King, The Moldovans. Romania..., p. 120.
} 
minorities who opposed the legislation, especially Russians. ${ }^{102}$

The question of minorities was in Moldova especially significant, as the republic had a large non-Moldovan minority - 35,7\% all in all, with the largest group being Ukrainian (584 196, 13,8\%) and Russian (540 900, 13\%). ${ }^{103}$ The rapid development of Moldovan nationalism, mirrored in the introduction of the new language Act, triggered harsh responses from the Russian-speaking minority in the Transnistrian region as well as from the Gagauz minority in the southern part of the republic. The question of minorities in Moldova was especially significant, as the republic had a large non-Moldovan minority population $-35.7 \%$ in all, with the largest group being Ukrainian (584 196, 13.8\%) and Russian (540,900, 13\%). ${ }^{104}$

Table 1. Largest minority groups in Moldova, 1989 and $2004^{105}$

\begin{tabular}{|c|c|c|c|c|}
\hline Groups & $\begin{array}{l}\text { Number of } \\
\text { persons } \\
\text { In } 1989\end{array}$ & $\begin{array}{l}\text { Number of } \\
\text { persons in } \\
2004\end{array}$ & $\begin{array}{l}\% \text { share of } \\
\text { total } \\
\text { population in } \\
1989\end{array}$ & $\begin{array}{l}\% \text { share of } \\
\text { total } \\
\text { population in } \\
2004\end{array}$ \\
\hline Ukrainians & 600000 & 283367 & 13.8 & 8.4 \\
\hline Russians & 562000 & 198144 & 13 & 5.8 \\
\hline Gagauz & 157500 & 147661 & 3.5 & 4.4 \\
\hline Bulgarians & 90000 & 65072 & 2 & 1.9 \\
\hline Other & 121500 & 44350 & 2.7 & 1.3 \\
\hline
\end{tabular}

\footnotetext{
${ }^{102}$ Daria Fane, Breaking Loose from Moscow, in:Nations and Politics in Soviet Successor States, ed. Ian Bremmer and Ray Taras (Cembridge: Cembridge University Press, 1993) p.122.

${ }^{103}$ Liliana Vitu, Foreign affairs of the Republic of Moldova: Does Moldova's Eastern Orientation Inhibit its European Aspirations? (Chisinau: Institutul de Politici Publice, 2010), p.16.

${ }^{104}$ Ibid.

105 „Largest minority groups in Moldova, 1989 and 2004 census figures”, National Office for Statistic 2007 in: Valeria Grosu, Country Profile: Moldova, Complendium Cultural Politics and Trends in Europe, accessed online 12 March 2012, http://www.culturalpolicies.net/down/moldova_112011.pdf
} 
Immediately after the introduction of a new language law ethnic minorities started to form their own national organizations, equivalent to Moldovan Popular Front. For example, several Transnistrian workers' collectives led by Igor Smirnof, a Russian factory manager who came to Moldova in November 1987, "united under the single banner of the Union of Workers Collectives (OSTK) and pursued a policy of secession from Moldova." ${ }^{106}$ Moreover, parallel to the establishment of OSTK, a Slavic militant group emerged from the organization Edinstvo, famous among the Soviet republics for its opposition to the reforms of the 1980s. The vehement nationalist movements of the minority groups were an answer to the progressing Moldovanization of the public life. Along with the removal of Russian as the dominant language, Moldovan authorities began closing the Russian schools and started to favor Moldovan nationals in the public administration. This course of events created fears among ethnic groups in Moldova of losing their national identity, social status and economic sovereignty. ${ }^{107}$ The slogans of the Popular Front regarding the unification with Romania, which became more popular day by day, only added insult to injury. As the summer of 1989 progressed, leaders of the Transnistria and Gagauz regions initiated massive strikes in enterprises in all cities with large Russian-speaking populations such as Tiraspol, Bender and Ribnita. ${ }^{108}$ Simultaneously, the emerging Russian minority's nationalist movement began to lobby Soviet authorities. It is worth noticing that the leadership of the Russian minority movement was largely made up of the Russian functionaries who had been dispatched to the Moldova Republic during the Gorbachev era. ${ }^{109}$ According to the International Crisis Group's report most of them were conservative communists who opposed the

\footnotetext{
${ }^{106}$ Christopher Borgen, Thawing a Frozen Conflict: Legal Aspects of the Separatist Crisis in Moldova (New York: The Association of the Bar of the City of New ,2006), p.15.

${ }^{107}$ B.a., Moldova - Narrative: Origins, Background and Conditions of the Moldova-Niester Conflict, University of Southern California, $\quad$ accessed online 19 June 2012, http://www.usc.edu/dept/LAS/ir/cews/database/Moldova/moldova.pdf , p.2.

${ }^{108}$ King, The Moldovans. Romania..., 129.

${ }^{109}$ B.a., Moldova: Regional Tensions over Transdniestria (Brussels: International Crisis Group, European Report nr. 157), p.2.
} 
reform policy of Mikhail Gorbachev and by leading the national movement of Russian- speakers in Moldova, wanted to keep the republic within the Soviet Union and to maintain their privileged position. ${ }^{110}$

As a result of those developments Moscow's authorities decided to support Transnistria's striving for separation from Moldova. This process had been accelerated by the Moldova's Supreme Soviet's decision to declare autonomy within the Soviet Union in July 1990. A two months later the Moldovan parliament, now called Sfatul Tarii, appointed as head of a state, the leader of Popular Front Mircea Snegur who was reluctant to any kind of dependence on Moscow and was a proponent of the reorientation toward Romania. As in consequence, tensions between the Kishinev and Moscow deepened. On September 2, 1990, the Soviet Interior Ministry mobilized troops to protect the Congress of the People's Deputies of the Transnistrian region from the "Moldovan nationalists" as it proclaimed the Dniestrian Moldovan Soviet Socialist Republic within the USSR, also known as DMR. ${ }^{111}$ Soon after the announcement non-Moldovan separatists along with the Soviet representatives commenced in taking local control over the major institutions and state administration. Moreover, KGB representatives and various Soviet ministries began to meet in regular sessions to discuss the future strategies, including military intervention and attitude toward the Moldovan government. ${ }^{112}$ Soviet leaders, in the face of growing nationalism in Kishinev, decided to sabotage Moldava's unification with Romania by threatening it with territorial disintegration.

In spite of ongoing tensions between Moscow and Kishinev regarding the Transnistia question, the slow agony of the disintegrating Soviet Empire pushed the two republics to attempt

\footnotetext{
${ }^{110}$ Ibid.

${ }^{111}$ B.a., Moldova: Regional Tensions over Transdniestria (Brussels: International Crisis Group, European Report nr. 157), p.2.

112 .a., Moldova: Regional Tensions over Transdniestria ..., p.2.

${ }^{112}$ Ibid.
} 
on September 22, 1990 to establish diplomatic relations. Leaders of both republics met in Moscow and signed the Moldovan- Russian Treaty of Partnership that constituted the interstate relations between the Socialist Republic of Moldova and the Soviet Socialist Federal Republic of Russia. ${ }^{113}$ For the Moldovan side this agreement was a first signal that the Russians might eventually accept the sovereignty of Moldova. However, for the Russians it was rather an attempt to maintain Bessarabia within the Soviet Union and to suppress the Moldovan independence movement. Eventually both of the Supreme Soviets in Moscow and Kishinev failed to ratify the Treaty and official diplomatic relations were not established until five years later.

Meanwhile minority leaders headed by Igor Smirnof, soon the first president of Dniestrian Republic, made moves to create their own governmental structure. They started to form their own ministries and took over all the buildings housing the Moldovan state institutions. Consequently over the next several months skirmishes between the central government troops and the armed separatists escalated, culminating in an prolonged fighting outside the city of Dubosari on November 2, 1990, between Moldovan police on one side and armed irregulars supported by the separatists on the other. ${ }^{114}$ In face of these events Mircea Snegur asked Mikhail Gorbachev to put an end to the secessionist conflict. ${ }^{115}$ In return he offered to accept the Russian proposal of "Union of Sovereign States" which meant the reorganization of the Soviet Union into a new confederative body. However, Gorbatchev did not take the offer and instead on November 25 he sent the troops of the Soviet Interior Ministry in order to protect the planned elections for the Supreme Soviet of the breakaway DMR ${ }^{116}$ President Snegur, in turn, officially decided to fulfill the main goal of the Moldovan Popular Front and to proclaim independence from Moscow.

\footnotetext{
${ }^{113}$ Vitu, Foreign affairs of the Republic of Moldova ..., p.17.

114 Pal Kolso, Andrei Edemsky, and Natalya Kalashnkova, The Dniester Conflict: Between Irredentism and Separatism (Glasgow: Europe-Asia Studies, 1993), p.984.

${ }_{115}$ Borgen, Thawing a Frozen Conflict: Legal Aspects of the Separatist Crisis ..., p.15.

${ }^{116}$ Moldova: Regional Tensions over Transdniestria..., 3.
} 
In order to do so, already at the end of the year he commenced with the formation of the government of an independent state with the prime objective to preserve its territorial integrity. ${ }^{117}$ It is worth noticing that the "Snegur Plan" provided special policy toward ethnic groups that would enable them to easily adapt to the new political system. For example, the Radio Free Europe news read that the new government of Bessarabia was going to promote "a revival of the Ukrainian, Gagauz and Bulgarian languages and cultures in Moldova, long subject to russiafication, and to encouraging (sic) Russians to renounce Soviet ideology in favor of Russian cultural traditions. $" 118$

As a result of the growing disagreements between Moscow and Kishinev the latter boycotted the all-Union referendum on March 17 concerning the future membership in the proposed successor state of the USSR. Voting took place only in Transnistria where "the vote was supposedly $93 \%$ in favor of the unitary Soviet state." ${ }^{119}$ Simultaneously, the presidential elections were held in the breakaway region where Igor Smirnof, the head of the radical communist camp, had been elected.

In the first half of 1991 the situation in Moldova and its separatist region of Transnistia was rather stable. ${ }^{120}$ Occasional clashes between Russian supported rebels and Moldovan troops appeared in the cities of Bender and Dubosari but they were considered more as fights between local hooligans than regular armed conflict. Transnistrian authorities with Soviet representatives focused on dissolving the Moldovan financial, administrative and military institutions and creating Dniestrian ones instead. In April the Chairman of the USSR Supreme Soviet, the KGB

\footnotetext{
${ }^{117}$ Vladimir Socor, Moldova's New: Government of National Consensus, RFE/RL, accessed online 12 April 2012, http://www.rferl.org/search/?k=socor\#article

${ }^{118}$ Vladimir Socor, Moldova Builds a New State, Radio Free Europe/Radio Liberty, accessed online 12 April 2012, http://www.rferl.org/search/?st=article\&k=socor\&df=07\%2F27\%2F $1993 \& d t=09 \% 2 \mathrm{~F} 27 \% 2 \mathrm{~F} 1995 \&$ ob $=$ rel\#article

${ }^{119}$ Borgen, Thawing a Frozen Conflict: Legal Aspects of the Separatist Crisis..., p.15.

${ }^{120}$ Moldova - Narrative: Origins, Background and Conditions, p.4.
} 
directors and Russian ministries discussed the plausible dissolution of Moldovan law enforcement bodies and as a result a month later all of them were put under Transnistian jurisdiction and the local police and judiciary branches were established. ${ }^{121}$ Moreover, the Russian Agroprombank created the first branch of the National Bank of Transnistria in which the local enterprises opened accounts forming the first state budget. ${ }^{122}$ Finally, the $14^{\text {th }}$ Soviet army, stationed in the region, as yet unofficially supporting the rebels in skirmishes with the Moldovan government, began to provide direct military aid to the insurgency, supplying it with the weapons indispensable for fighting with central government. At the same time Moldova became virtually cut off from the rest of the Soviet Empire. "The major rail and road links to Ukraine and beyond run through the east-bank city of Rybnita, Dubasari, and Tiraspol, all of whose local councils had declared their allegiance to the Transnistrian republic." ${ }^{\prime 23}$ In response, in March the Moldovan authorities issued protest notes to Supreme Soviet and Russian defense ministry complaining about the army's assistance to the rebels. ${ }^{124}$ It noted, inter alia, that the soldiers of Soviet $14^{\text {th }}$ army helped to form the new DMR army and the Dniestr Guards that was commanded by the high ranking officers of the Russian army.

The events of August 19-21 involving the unsuccessful attempt to overthrow Gorbatchev proved to be a turning point in Russian- Moldovan relations as well as for the future course of the Transnistrian conflict. ${ }^{125}$ The August putsch, as the overthrown was later called, had its roots in the ever weakening position of the communist party within the Soviet state and in the process of gaining power by the new liberal political leadership advocating the disintegration of the current

\footnotetext{
${ }^{121}$ B.a., TransNistria, No. 20, June 1992, p.3, citing documents confiscated by the Soviet General Prosecutor in: Moldova: Regional Tensions over, p.3.

122 Vladimir Grosul, Istoria Pridnestrovskoj Moldavskoj Respubliki (Tiraspol: Transnistrian Institute of the Continuing Education, 2001), p.310.

${ }^{123}$ King Charles, The Moldovans. Romania..., p.190-191.

${ }^{124}$ Ibid.

${ }^{125}$ Fane, Breaking Loose from Moscow..., p.123.
} 
the Soviet state. Many of the hardline communists strongly opposed all of the new reforms, especially the project of the "Union of Sovereign States" proposed by Gorbatchev, which would have given more power to the republics' governments and consequently weakened the position of the "ruling class" in the Kremlin. In order to prevent the new reforms and save their power credentials, "part of the top-level party and state administration members tried to take the power in their hands ... and to restore the former, pre-1985 situation in the USSR, that is to eliminate multi-party system, commercial structures, in destroying the rudiments of democracy." Fortunately, the putsch was organized very poorly and neither population nor army supported the use of force against the legitimate power and the citizens who defend it. ${ }^{127}$

The August coup emphasized the significant differences between Moldova and Transnistria as the reactions of the regional authorities to the putsch were completely different. In Kishinev, for example, the Moldovan Communist Party leaders headed by Grigore Eremei and the Popular Front led by Mircea Snegur sided against the putsch organizers. In Transnistria, on the other hand, Igor Smirnof "publically praised the putschists as saviors of the Soviet state and promised military assistance to support the state of emergency." 128 Transnistria's attachment to hardline communism attracted unreformed communists from other Soviet republics and after the coup some of them, like Vladimir Shevtsov, took high offices in the breakaway republic. ${ }^{129}$

Most importantly, the unsuccessful putsch and the defeat of the camp that wanted to preserve the USSR hastened Moldova's independence decision. On August 27, 1991, Alexander Mosanu, president of the Moldovan parliament, proclaimed Moldova's independence from the

\footnotetext{
${ }^{126}$ B.a., The putsch of August 22,1991, Russia the Great, accessed on-line 12 April 2012, http://russia.rin.ru/guides_e/7227.html

127 Ibid.

${ }^{128}$ King, The Moldovans. Romania ..., p.191.

${ }^{129}$ Vladimir Shestov was a former head of the Soviet OMON Special Forces in Riga, Latvia.
} 
Soviet state and took control over Soviet assets on the Moldovan territory. ${ }^{130}$ This declaration "invoked historical rights and democratic legitimacy as the basis for statehood" and called the world's states for recognition of independent Moldova and establishment of diplomatic relations with the country. ${ }^{131}$ Moreover, the government of the newly independent state immediately passed a series of resolutions regarding the formation of the central and local state institutions that would take over all of the responsibilities performed until then by the Soviet authorities. In addition, the parliament "passed a decree rescinding all articles in the republic's constitution that related to Moldova's membership in the Soviet Union". A special delegation was also sent to Moscow in order to discuss the matters regarding the succession from USSR. ${ }^{132}$ They agreed, for instance, that Moldovan government would take over all the enterprises belonging to the Soviets, including the heavy-industry factories on the territory of DMR (later confirmed in the parliament's decree no. 234 on November 14, 1991). ${ }^{133}$ Several days after the declaration Snegur along with most notable Moldovan politicians, commenced negotiations with government in Bucharest regarding the eventual reunification of the country with Romania.

The news about the possible unification with Bucharest raised panic among the Dniestrian officials. The critical moment came when Kishinev targeted the leaders of the separatist movement, including Igor Smirnof, arrested them and charged them with supporting the illegal Moscow coup. ${ }^{134}$ In response the DMR threatened the Moldovan government with cutting the gas and electricity supplies as well as blocking the rail lines leading west of the river. ${ }^{135}$ Once the leaders were released on September 2, 1991, the Supreme Soviet of Transnistria adopted its own

\footnotetext{
${ }^{130}$ King, The Moldovans. Romania..., p.191.

${ }^{131}$ Fane, Breaking Loose from Moscow..., p.123.

${ }^{132}$ Ibid.

${ }^{133}$ B.a., Russian-Moldovan talks, Isvestia, October 30,( 1991),No. 1.

134 John O'Loughlin, Vladimir Kolossov, and Andrei Tchepalyga, “ National Construction, Territorial Separatism, and Post-Soviet Politics" in : the Transnistrian Moldovan Republic (New York: Post Soviet Geography and Economics 39, No 6, 1998), p.342.

${ }^{135}$ King, The Moldovans. Romania ..., p.191.
} 
constitution, officially proclaimed its independence from Moldova and announced its incorporation into the Soviet Union. Smirnof later explained this decision by arguing that this declaration was necessary to protect the Russian and Ukrainian minorities in the DMR from the possible reunification of Moldova with Romania. ${ }^{136}$ Taking into account the violent conflict between Russians and Romanians in the region, Transnistrians with reasons felt they might be oppressed under Romanian rule. ${ }^{137}$

In regards to the Soviet Union itself, after the victory of Yeltsin camp it was obvious that the Union would dissolve sooner or later. After the coup attempt the fear that the Gorbachev's reforms would be withdrawn pushed the Soviet republics to quickly declare independence from the Union. Consequently on December 8, 1991, the representatives from Moscow along with leaders from Belarus and Ukraine signed an agreement dissolving the Union and establishing the Commonwealth of Independent States (CIS) instead an entity in which Moldova would eventually take an active part. ${ }^{138}$

\section{The Relations between Sovereign States.}

\section{The Transnistrian Conflict}

Even though the Soviet empire had collapsed Russian authorities still wanted to maintain their grip on former Soviet republics, including Moldova and Transnistira, through the CIS organization. On the other hand the newly born states wanted to assure their sovereignty and

\footnotetext{
${ }^{136}$ Borgen, Thawing a Frozen Conflict: Legal Aspects of the Separatist ..., p.15.

${ }^{137}$ B.a., Snegur Interviewed on Dniestr Conflict, FBIS Daily Report - Central Eurasia (Vol. 2, June 1992, p.67-71.

${ }^{138}$ Steve Crawshaw, Goodbye to the USSR: The Collapse of Soviet Power (London: Bloomsbury, 1992), p.86.
} 
were very cautious about joining an organization dominated by the Russians. Nevertheless, they were drawn to the organization by economic necessity. ${ }^{139}$ Moreover, in case of Moldova the threat that Russia might get involved in the ethnic conflict within the Moldavan state, if Kishiniev refused to join CIS, was an additional factor that compelled the country to apply for a membership.

Still hoping to avoid Russian influence, at the beginning of the negotiations in Moscow in December 1991, president Snegur strongly opposed the formation of CIS, seeing it as a different form of the Russian control similar to that of the Soviet Union. On December 8, 1991, Radio Free Europe/ Radio Liberty (RFE/RL) quoted the president who said that "with every passing day, ... the desire of certain state leaders to return to the organization of the former USSR is becoming increasingly apparent... ." Nevertheless, the broken economic ties between the Soviet entities had serious repercussions on people's living conditions, which in turn made the political situation in Moldova unstable and forced Snegur to plead for economic cooperation with CIS states. ${ }^{141}$ After the collapse of the Soviet Union Moldova relied almost exclusively on the former Soviet republics for raw materials and fuel. ${ }^{142}$ Although it tried to find new economic partners outside the post-Soviet world, it was highly difficult as foreign countries conditioned their cooperation with the Former Soviet Republics on the Russians' reaction. For example, in 1992 the only countries that established economic relations with Moldova were, obviously, Romania, Bulgaria, Kuwait, the United States and Israel.

The main sticking point between Moldovan authorities and the CIS was the military cooperation clause that included the prohibition of maintaining countries' own arm forces and the

139 Robert J. Smith Jr., Russia and Moldova: Developing Relations between Two Countries (Monterey: Naval Postgratuate School, 1993), p.21.

${ }^{140}$ Vladimir Socor, Moldova not to sign CIS Charter, RFE/RL, 8 December 1991.

${ }^{141}$ B.a., Interview with President Mircea Snegur, BASA-press, accessed online 20 April 2012, www.basa.md

${ }^{142}$ Smith , Russia and Moldova: Developing Relations..., p.23. 
establishment of joint military command structures (which meant in practice agreeing to CIS army's presence in the member states). For Moldovans this reservation meant that they agreed to the presence of $14^{\text {th }}$ army that had provided assistance to the insurgents in fighting with Moldovan troops in Transnistira. Moreover, even though the statutes of CIS forbade the interference into the domestic affairs of any member state, every member had the right to engage in "measures that aim at the suppression of the danger that might occur in respect to the sovereignty, security and territorial integrity of a member state of the commonwealth." 143 This meant in practice that the Russian army, for example, could enter the territory of Moldovan republic every time they assumed the security or sovereignty of the state was in danger. However, unlike the previous union CIS, did not possess the supranational prerogatives that would allow the organization to constantly interfere in the domestic policy of constituent states and was more focused on the intensification of interstate cooperation. ${ }^{144}$

In the middle of December 1991 Moldova signed the CIS chapter (also called the AlmaAta Protocol) that established the Commonwealth of Independent States with the reservation that Moldova would not enter the structures of military cooperation within the organization. ${ }^{145}$ This decision strongly influenced the later Russian-Moldovan relations as Moscow repeatedly tied the withdrawal of the $14^{\text {th }}$ army to Moldova's participation in some type of security arrangement with Russia. $^{146}$

Meanwhile, the new Russian authorities with reformist Boris Yeltsin as a head of the state

143 Agreement on the Establishment of the CIS 1991, (2/1991, Kishinev, 8 December 1991), accessed online 31 March 2012, http://cis.minsk.by/reestr/ru/index.html\#reestr/view/text?doc=1

${ }^{144}$ Borgen, Thawing a Frozen Conflict: Legal Aspects of the Separatist ..., p.19.

145 This reservation was also made by two other member states: Ukraine and Azerbaijan.

146 Agreement on the Establishment of the CIS $1991 \ldots$. 
faced the challenge of creating a new foreign policy toward "the Near Abroad". ${ }^{147}$ So far, the directions of policy were indicated by communist ideology so when the Soviet Union dissolved Russia's first priority became to define the national interest that would, in turn, determine the foreign policy of the state. ${ }^{148}$ To define the national interest it was necessary to decide who belongs to the Russian nation. The question was whether the Russian nation meant all the Russian speakers, including those who lived outside the Federation, or should it be confined only to people of the Russian descent. The Ministry of the Foreign Affairs led by Andrei Kozyrev, which was responsible for determining the policy guidelines, was still in the hands of the "hard liners" who wanted to maintain Russian power over the former Soviet republics. Respectively, the Ministry quickly figured that if the main goal of the foreign policy would be to protect the Russian-speaking people living in post-Soviet states, the Russian government would have an easy excuse to intervene in the post-Soviet space. In February 1992, for example, Kozyrev stated that "while Russia respected the sovereignty of the newly-formed states Russia would strictly defend its own interests...including not only economic ties but preservation of a unified army... and the protection of the Russian and Russian-speaking population in other CIS states."

\footnotetext{
147 The tern „, Near Abroad” (ближнее зарубежье) concerns the newly created states which gained independence after the collapse of the Soviet Union. The tern was introduced by the Foreign Policy Minister Andrey Kozyrev to determine the area of the Russia's sphere of influence.

${ }_{148}$ Smith, Russia and Moldova: Developing Relations..., p. 24.

${ }^{149}$ Smith, Russia and Moldova: Developing Relations..., p. 31.
} 


\section{Russian Involvement in the Transnistrian War}

Taking under consideration the Russians' new foreign policy approach it is easy to conjecture their attitude toward the Transnistrian conflict and the independent Republic of Moldova itself. The majority of the diplomatic relations between the end of 1992 and 1999 revolved around Russian involvement in the Dnister conflict and finding a solution to this problem that would satisfy all three sides.

In early 1992, as the conflict between the secessionists and the Moldovan troops intensified the newly elected president of Dniestrian republic Smirnof began a "campaign of harassment" to throw all "pro-Moldovan elements" out of the separatist republic. ${ }^{150}$ To be able to implement this plan the government in Tiraspol asked Moscow for support. In response, Kremlin, sent hundreds of mercenaries, Cossacks and other military personnel to the Dniester region through the Ukrainian border. ${ }^{151}$ "The Cossacks and other volunteers were put on the Russian state payroll, receiving 3000 rubles a month."152 Moreover, some sources reported that the separatist government was granted several million rubles in aid to support its military activists by the authorities in Moscow. ${ }^{153}$

The major element of the Russian involvement in the conflict in Moldova was the Soviet 14th army stationed on the left bank of the Dniester river. When the government in Kishinev did not agree to join the military structure of CIS and demanded to be given control over all Soviet

\footnotetext{
${ }^{150}$ Borgen, Thawing a Frozen Conflict: Legal Aspects of the Separatist ..., p.19.

${ }^{151}$ Smith , Russia and Moldova: Developing Relations..., p.40.

${ }^{152}$ Kolso, The Dniester Conflict: Between Irredentism ..., p.987.

153 David Neuman, Boundaries, Territory and Postmodernity (London: Routledge Studies in Geopolitics, 1991), p.72.
} 
army forces and equipment located in Moldova Russians rejected those demands. ${ }^{154}$ However, seeing that the presence of army in Transnistria was a great bargaining chip in the shaping of Moldova-Russia relations they left the status of the $14^{\text {th }}$ army to further negotiations. A couple of weeks later "the commanding general of $14^{\text {th }}$ Army, Lieutenant General Gennadii Yakovlev, accepted the position of Chief of Defense for the Dniester Republic and placed the $14^{\text {th }}$ Army troops and equipment at the disposal of the government." ${ }^{\text {155 }}$ Consequently at the beginning of the year, the $14^{\text {th }}$ army occupied Grigoriopol, Dubosari Tiraspol and Ribnita so that Moldovan troops could not enter the cities and prevent the planed secession. ${ }^{156}$

The skirmishes escalated into outright war in March, just after Moldova's accession to the United Nations on March 2, 1993. Transnistrian forces led by the high-ranking Russian officers, along with $14^{\text {th }}$ Army's soldiers, attacked police offices in Bandera and Dubosari. The Moldovan army was not able to take control over the cities. The fighting lasted for a couple of weeks and resulted in approximately 1000 deaths, while 130,000 people were either internally displaced or sought refuge in other countries. ${ }^{157}$ This course of events was a shock for Moldovan authorities. They immediately protested to the CIS organs calling for the CIS military to intervene in the conflict as peacekeepers along with United Nations peacekeeping mission. ${ }^{158}$ However, as Russia had a dominant position in the organization and used it rather as an instrument of influencing the policy of the former Soviet republics, CIS did not meet Kishinev's demands. Additionally, at the Helsinki Foreign Ministers Conference, Kishinev, along with the Romanian representatives, protested the activities of the separatist troops as well as the obvious Russian support of the insurgents. In response to their call Boris Yeltsin signed the decree which placed the $14^{\text {th }}$ Army

\footnotetext{
${ }^{154}$ Vladimir Socor, Russia Forces in Moldova, RFE/RL Research Raport, vol 1, no. 34, 28 August 1992, p.39.

${ }^{155}$ Socor, Russia Forces in Moldova ..., p.39.

${ }^{156}$ Borgen, Thawing a Frozen Conflict: Legal Aspects of the Separatist ..., p.16.

${ }^{157}$ King, The Moldovans. Romania ..., p.178.

${ }^{158}$ Smith, Russia and Moldova: Developing Relations..., p.23.
} 
under the Yeltsin's personal command, what made it impossible for Moldova to take over the command of the $14^{\text {th }}$ Army. ${ }^{159}$ One of the Army's Commanders, Jevgenii Nietkachov proposed that the $14^{\text {th }}$ Army would become the peacekeeping force. This was ridiculous, taking into consideration the role the Army had played in the conflict so far. ${ }^{160}$ In Moscow Vice-President Aleksander Rutskoi openly supported the Transnistrian separatist movement, called the Russian Congress of Peoples Deputies to recognize Dnistrian sovereignty and to support the Transnistrians in their conflict with the Moldovan government. The Russian Congress of People's Deputies applied those instructions on April 8, 1993. ${ }^{161}$ A month later Rutskoy visited the breakaway region and gave a speech in which he emphasized the responsibility of the Russian authorities to protect the 25 million Russians who were living outside Russia's borders and promised to intensify the Russian support if needed. Rafał Morawiec, the specialist on Moldova's politics from the Polish Academy of Science, pointedly called Russian policy toward Moldova and Transnistria as an new "Brezhnev Doctrine." 162

But not everyone in the Kremlin supported this radical stand on the Dniestrian conflict. Both major foreign policy representatives, Boris Yeltsin and Minister Kozyrev called for Moldovan territorial integrity and commenced peace negotiations. ${ }^{163}$ In order to gain more control over Russian forces stationed in the region Yeltsin decided to replace the previous Commander-In-Chief with the Major General Alexander Lebed, the battalion Commander in the Soviet war in Afghanistan. Unfortunately, it appeared that Lebed not only less subordinate than

\footnotetext{
${ }^{159}$ Celestine Bohlen, Russian takes over Command of Army in Moldova, (New York: NY Times, April 2 1992), p.32.

${ }^{160}$ Rafał Morawiec, Mołdawia 1992, (Warszawa: Rocznik Europy Środkowo-Wschodniej, 1993),p.129.

${ }^{161}$ Smith , Russia and Moldova: Developing Relations..., p.40.

${ }^{162}$ The Brezhnev Doctrine was a Soviet foreign policy outlined in 1968 which called for the use of Warsaw Pact forces to intervene in any Eastern Bloc nation which was seen to compromise communist rule and Soviet domination, either by trying to leave the Soviet sphere of influence or even moderate its policies : Morawiec, Moldawia $1992 \ldots$, p.129.

${ }^{163}$ Suzanne Crow, Russian Moderates Walk a Tightrope on Moldova, RFE/RL Research Raport, vol 1, no. 20,15 May 1992, p.11.
} 
the previous Commander but was also a hardline communist and the biggest opponent of the reformist policy of Yeltsin. While performing his duties Lebed very often provoked the Moldovan government by calling its leaders "Moldovan Fasists". He also said that President Mircea Snegur was "negotiating with Yeltsin only in order to mislead public opinion, while in reality (he was) preparing for war." ${ }^{\text {164 }}$ Increasingly unauthorized actions of individual $14^{\text {th }}$ Army units were reported in the summer 1992 in what was perceived as if the Kremlin was losing complete control over the Russian forces. "Orders were not executed, individual units broke away and solders, paid more by the separatists than by the Russian state, entered into their militia." 165

\section{The Peace negotiations}

In response to losing control over developments in Transnistria Yeltsin decided to intervene to halt the conflict in July 1992. The decision was driven mostly by Yeltsin's desire to stabilize the domestic conflict in Russia where his reforms came under attack by the hardline communist camp and extreme nationalists. For instance, the Congress of People's Deputies - the supreme organ of power in the Federation dominated by Yeltsin opponents, was systematically reducing presidential powers, including the power of appointing of administrative offices. ${ }^{166}$

Thus, in order to please the opposition Yeltsin decided to commence the peace

\footnotetext{
${ }^{164}$ Bohdan Nahaylo, National Ferment in Moldova, RFE/RL Research Raport, vol 32, no. 20, 24 January 1988, 4. cited by: Smith Jr., Russia and Moldova: Developing Relations..., p.43.

${ }^{165}$ Pavel Baev, The Russian Army in the Time of Troubles, ( Oslo: International Peace Research Institute, 1996) cited in: Andrea Morike, The Military as a Political Actor in Russia: the Cases of Moldova and Georgia, (Kishinev: International Spector, 1998), p.122.

${ }^{166}$ Allen C. Lynch, "The Evolution of Russian Foreign Policy in the 1990's “, The Journal of Communist Studies and Transition Politics, vol 18, (2002), p.164.
} 
negotiations with Moldova that would eventually result in the proclamation of independence of the breakaway Transnistrian territory. Kishinev had proposed quadripartite talks with assistance from the Ukrainian and Romanian governments but the Russian side disagreed saying that the most effective negotiations would be between the Russian and Moldovan authorities. After a couple of days of negotiations, on 21 ' July the sides reached the solution that included: “ Implementing a cease-fire, creating a demarcation corridor between the forces, introducing the neutral peacekeeping forces, granting a political status to the left bank of the Dniester by the Moldovan parliament and ultimately scheduling the bilateral negotiations on withdrawing the $14^{\text {th }}$ Army." ${ }^{167}$ Russian representatives also promised to restore trade between the two countries that had been suspended by the Federation after the Moldovan declaration of independence.

During the implementation of the peace arrangements the most difficult part was the establishment of the peacekeeping forces. Kishinev insisted that the mission be made up of CIS and UN troops while Moscow preferred the peacekeeping forces to be constituted out of the Russian forces, meaning the $14^{\text {th }}$ Army and only eventually Moldovan and Transnistrian soldiers. ${ }^{168}$ Russian agreed not to engage the $14^{\text {th }}$ Army in the peacekeeping mission but instead to send some additional Russian troops to the region. Moldova agreed to this scenario and in mid-July the peacekeeping mission that was composed of 3800 Russian, 1200 Moldovan and 1200 Dniester solders was sent to the left bank. ${ }^{169}$ The Moldovan decision was very controversial. By agreeing to accept additional Russian troops as peacekeepers on its territory in practice the Moldovan government agreed to enlarge the Russian contingent stationed in the region and thus allowed the Russians to increase their control over the course of events in Transnistria. Later, during an interview President Snegur stated that sending Russian troops was the only chance to

\footnotetext{
${ }^{167}$ B.a., Moldova-Narrative: Origins, Background and Conditions of the Moldova.., p.5.

${ }^{168}$ Smith , Russia and Moldova: Developing Relations..., p.23.

${ }^{169}$ Ibid.
} 
form the peacekeeping mission because the UN organs did not agree to send troops to the region while the conflict was still ongoing. ${ }^{170}$

A couple of days after the deployment of the peacekeeping mission to the region the first complaints about its activities appeared. The Moldovan president asked the UN to send international observers because of "the rising doubts about the other side's sincerity." ${ }^{171}$ The President claimed, for instance, that the peacekeeping forces allowed the formation of the independent institutions of the Transnistrian government and thus strengthened the secessionist movement. The promised negotiation regarding the withdrawal of $14^{\text {th }}$ Army also did not bring the expected results. Every time the Moldovan foreign Minister wanted to commence the talks the Russian authorities postponed them. Finally Minister Kozyrev officially stated that the withdrawal of the Russian forces would only be possible when Moldova considered military cooperation within the CIS military structure. ${ }^{172}$ To sum up, after the negotiation Moldova ended up having 3800 more Russian soldiers on its soil and the fully formed institutions of the secessionist government thanks to the deployed international peacekeeping mission. This situation definitely did not satisfy the Moldovan authorities. The Russian intervention into the conflict and the continual pro-DMR rhetoric from the Russian Duma convinced many leaders that the Russian Federation was intent on using the Transnistiran crisis as a way of exercising control over Moldovan domestic affairs." ${ }^{173}$

\footnotetext{
${ }^{170}$ Vladimir Socor, Moldovan President appeals to UN, RFE/RL Daily Report, vol. 1, no. 52, 3 August 1992, p.17. ${ }^{171}$ Ibid.

${ }^{172}$ Vladimir Socor, Moldova facing Russian Pressure, RFE/RL Research Raport, vol 1, no. 52, 15 December 1992, p.39.

${ }^{173}$ King, The Moldovans. Romania..., p.198.
} 


\section{Frozen Conflict ${ }^{174}$}

"The result of the Russian intervention was that Transnistria became effectively portioned form the rest of Moldova, the fighting cooled, and was replaced by a frozen conflict."175 Although the fighting between the troops almost stopped neither Russia and Moldova nor Transnistria and Moldova reached any peace agreement. Moldova abandoned all hopes concerning the rapid withdrawal of the $14^{\text {th }}$ Army after the Russian Minister of Defense, Pavel Grachev, stated " the withdrawal of $14^{\text {th }}$ Army from the Dniester area will only be possible when the conflict in the region is settled." ${ }^{176}$ In DMR, on the other hand, Smirnof's advisor Valeri Litskai (latter appointed the Foreign Minister) demanded the formation of a Federalist state consisting of three entities: the Republic of Moldova, the Soviet Republic of Transnistria and the Republic of Gagauz. President Snegur immediately rejected this proposal and stated that he would oppose any kind of the transformation of Moldova into the federative structure. He also added that he would oppose the creation of the sovereign Dniester state with its own army forces, borders, and security services and might only agree on the creation of Dniester autonomy within the Moldovan state. ${ }^{177}$

In February 1993 the presidents Yeltsin and Snegur met in the Kremlin to discuss the most burning questions in the relations between two countries. The meeting was considered to be the third round of negotiations for withdrawal of the Russian troops. During the talks Snegur

\footnotetext{
174 'Frozen conflicts' are defined as those in which violent ethnopolitical conflict over secession has led to the establishment of a de facto regime that is recognized by neither the international community nor the rump state from which the secession occurred, In: Ghia Nodia, "Europeanization and (Not) Resolving Secessionist Conflicts", Journal of Politics and Minority Issues in Europe, vol. 5, no. 1., (2004).

${ }_{175}$ Borgen, Thawing a Frozen Conflict: Legal Aspects of the Separatist ..., p.17.

176 B.a., Moldova - Narrative: Origins, Background and Conditions of the Moldova.., p.6.

${ }^{177}$ B.a., Moldova - Narrative: Origins, Background and Conditions of the Moldova.., p.6.
} 
proposed the creation of a free trade zone in Bender, granting the DMR a special political status within the state, and complying with international norms regarding the rights of minorities in the country. Both Russia and Transnistrian leaders did not agree to this proposal and demanded the formation of an independent Dniestrian army. Boris Yeltsin, when asked about the precise date of withdrawal of the Russian Army from Transnistria, proposed that part of the contingent might be disbanded, which would mean in practice the transfer of soldiers and their equipment to the Transnistrian Guard. In face of the lack of any agreement Moldova started to seek a helping hand in the adjacent neighborhood. On February 19, 1993 Moldova signed a Treaty with the Ukrainian government on cooperation between the national custom services in order to reduce the transit of goods to the DMR as well as to suppress the infiltration of the Russian mercenaries. In this way Ukraine tried to implement the plan of creating the kind of regional alliance that would serve as counterbalance to Russian domination. ${ }^{178}$

Moscow's reaction was harsh as usual. Russia punished Ukraine for making deals behind Russia's back by voting on reclaiming Sevastopol as Russian territory. It also turned against the government in Kishinev. Kremlin used trade barriers to make exports to Russia from Moldova completely unprofitable. As sales to Russia and other CIS countries dominated the Moldova economy, the financial stability of the country was completely dependent on the trade relations with Russia. In this case the government in Kishinev did not have much of a choice. In September, during the CIS countries meeting, both sides agreed that Moldova in return for lifting the trade restrictions on January 1, 1994, would sign the Agreement of Creation of CIS and thus became a full member of the organization without any restrictions. ${ }^{179}$ The Agreement entered into force on April 8, 1994. Moreover Moldova signed the CIS Human Rights Convention as well as

\footnotetext{
${ }^{178}$ Alicja Sowińska-Krupka, Mołdawia 1993, (Warszawa: Rocznik Europy Środkowo-Wschodniej, 1994) p.121.

${ }^{179}$ Agreement on the Establishment of the CIS 1991... .
} 
joined the economic cooperation board and the Committee of the Foreign Ministries CIS created to coordinate the common foreign policy of the CIS countries. ${ }^{180}$ When news about the Snegur's decision reached Kishinev protests broke out all over the century. The pro-Romanian and proEuropean camps stated that "Russia will use the economy to enslave Moldova politically and as long as the occupational $14^{\text {th }}$ Army stays in Moldova, we can make no arrangements with Russia." ${ }^{181}$ Reporters of BASA-press informed that around 200 people protested on the parliament square against Moldova's entrance into CIS shouting slogans like " The Parliament wants us to have an economic, political, social and cultural Gulag." 182 Yet, the protests of the Moldovan opposition were silenced for a while when in October the constitutional crisis in Moscow engaged the Moldovan and Transnistrian authorities. The crisis broke out when Yeltsin dissolved the main legislative body, the Congress of People's Deputies, led by his mail opponent, Ruslan Chasbulatov. ${ }^{183}$ In response, the Russian parliament impeached Boris Yeltsin and replaced him with the hardline communist, vice president Alexander Rutskoy. When on October 3, 1993 the Russian Army, obedient to the old president, stormed the parliament building the DMR authorities came out against the Yeltsin leadership and promised armed support for Chasbulatov and Rutskoy. Ten days later, after the arrests of the impeachment leaders, Yeltsin decided to tackle the rebellious DMR leadership. "The Russian Central Bank froze Transnistrian assets, stopped supplying rubles... and Defense Minister Grachev ordered the $14^{\text {th }}$ Army, commander, General Alexander Lebed, to sever relations with the criminal DMR government, accusing its leadership of corruption and involvement in the illegal arms trade." ${ }^{184}$ Although the

\footnotetext{
${ }^{180}$ Sowińska-Krupka, Mołdawia 1993..., p.121.

${ }^{181}$ Vitu, Foreign affairs of the Republic of Moldova..., p.21.

${ }^{182}$ Vitu, Foreign affairs of the Republic of Moldova..., p.21.

${ }^{183}$ Nicholas Riasanovsky, Mark Steinberg, History of Russia (Oxford: Oxford University Press, 1999), p.532.

184 John Matz, Constructing a post-Soviet international political reality: Russian foreign policy towards the newly independent states, 1990-95 (Uppsala: Uppsala University, 2001, 227. quoted in: Moldova: Regional Tensions over Transdniestria..., p.4.
} 
Moldovan leadership considered it to be the turning point in the Russian-Moldovan relations regarding the Transnistrian conflict, its happiness was premature. It proved to be a spontaneous reaction of Yeltsin that was very quickly explained by Kozyrev who said that "the Transnistria' leadership attitude toward constitutional crisis in Moscow had nothing to do with the protection of the Russian national interests in the region." 185

\section{The Russian- Moldovan Relations: Warming Up?}

In early 1994 the political climate in Kishinev had drastically changed. In February the Agrarian Democratic Party won in the parliamentary elections getting the majority of the seats in the parliament. This reformist communist organization backed the closer ties with the Russian Federation and other former Republics and was, accordingly, against close cooperation with Romania. Petru Lucinschi, Speaker of Moldovan Parliament, advocated Moldova's entrance into CIS structures and intensification of economic cooperation, including the Free Trade Zone within the CIS territory. He was also a fervent proponent of the "proportional integration" which meant

the simultaneous integration of Moldova with European and CIS structure. ${ }^{186}$ Lucinschi, on the other hand, strongly opposed the presence of the foreign troops on the Moldovan territory. Therefore, just after the elections, the Moldovan parliament adopted the neutrality clause (Article 11) of 1994 Moldovan constitution that made foreign military presence on the Moldovan territory

\footnotetext{
${ }^{185}$ Sowińska-Krupka, Mołdawia 1993 ..., p.122.

${ }^{186}$ Vitu, Foreign affairs of the Republic of Moldova..., p.22.
} 
illegal. $^{187}$

Further improvement of Russian-Moldovan relations occurred with the results of the referendum on the future integration of the country with Romania. It turned out that the proRomanian and anti-state position of the Popular Front was backed only by the small minority of population and over 95 percent of voters favored Moldova's continuing independent statehood. ${ }^{188}$ Moldova's full accession to the Commonwealth of Independent States softened Russia's attitude towards the demands of withdrawal of the $14^{\text {th }}$ Army's from the DMR. The shift in Russian policy was also a result of pressure from the Organization for Security and Co-operation in Europe (OSCE), which in July adopted a resolution disapproving Russian involvement the conflict. ${ }^{189}$ After two years of negotiation during the OSCE Budapest Summit on October 24, 1994, Moldova and Russia signed the agreement that called for the Russian Army's withdrawal within three years from the date of the entry into force of the agreement. ${ }^{190} \mathrm{Up}$ to this moment the Russians had linked the withdrawal of the troops to a settlement on the final status of Transnistria. It was a first time when the Federation did not add any sine qua non condition to the settlement. However, in view of the future NATO enlargement into the post-Soviet space, at the end of the year the Federation began to mention the maintenance of its forces in Moldova. ${ }^{191}$ The Russian Duma claimed "since the document was the international agreement on Russian military forces, it needed to be ratified by the Russian parliament first." ${ }^{192}$ The lower house, in turn, was overwhelmingly dominated by the hard-liner communists led by Chasbulatov, who would never agree on removing the Army without an agreement on the secession of DMR from the Republic

\footnotetext{
${ }^{187}$ King, The Moldovans. Romania..., p.200.

188 Steven D. Roper, "Regionalism in Moldova, The Case of Transdniestira and Gagauzia", cited by: ed. Oliver Schmidtke Belarus, Europe's Last Frontier?: Moldova, and Ukraine between Russia and the European Union, (London" Palgrave Macmillan, 2007).

${ }^{189}$ Alicja Sowińska-Krupka, Mołdawia 1994-1995 (Warszawa” Rocznik Europy Środkowo-Wschodniej, 1996$), 175$.

${ }^{190}$ Roper, Regionalism in Moldova, The Case of Transdniestira..., p.111.

${ }^{191}$ B.a., Moldova: Regional Tensions over Transdniestria...,p. 5.

${ }^{192}$ King , The Moldovans. Romania..., p.200-201.
} 
of Moldova. When the protests from Kishinev resounded Russian officials renamed and reorganized the $14^{\text {th }}$ Army into "Operational Group of Russian Forces"(OGRF) and thus made the agreement with Moldova invalid. Disappointed Moldovan leaders in a last-ditch attempt to solve the Russian Army issue on November 24, 1994 ratified the new constitution. The Article 111 of the document officially gave special autonomy status to the Transnistrian region and Gagauzia. ${ }^{193}$ Thus Moldovans insisted that the removal of the Russian troops begin with the granting of autonomy to the DMR but the Russian parliament claimed that the agreement would come into force only after its ratification by the Congress of People's Deputies.

Yet Moscow knew that the maintenance of the large military formations was not only very costly, taking under consideration the current economic situation in the country, but also pointless to some degree, since the DMR was of declining strategic value. ${ }^{194}$ Moreover at the beginning of 1995 the Transnistrian parliament passed the bill forbidding either withdrawing or decreasing the number of Russian soldiers stationed in the region. The case of Russian decision to withdraw the troops, all the assets including various kinds of equipment would be transferred to the DMR leadership. ${ }^{195}$ Tired of nursing the breakaway region which many times showed a lack of loyalty to the presidential camp the Russian Defense Ministry Pavel Grachev issued a decree significantly reducing the numbers of troops stationed in the DMR. Yet, a week later, on April 26, 1995, the Russian Duma passed a resolution forbidding the withdrawal of troops under the pretext of the threat of another outbreak of war in Moldova. ${ }^{196}$ In this instance Yeltsin decided to outwit the opposition in the Russian legislature and appointed as new commander of the OGRF

\footnotetext{
193 Constitution of Republic of Moldova 1994, July 29 1994, accessed online 21 April 2012, http://confinder.richmond.edu/admin/docs/moldova3.pdf

${ }^{194}$ B.a., Moldova: Regional Tensions over Transdniestria ..., p.5.

${ }^{195}$ Yuri Ataman, A case Study on Mediation Process in Moldova/Transdniestria (Stockholm: International Peace Research Center, 1998), p.11.

${ }^{196}$ Sowińska-Krupka, Mołdawia 1994-1995,p.175.
} 
Valerii Yevnevich who replaced the rebellious general Lebed. Loyal to the reformist camp Yevnevich quickly reduced the administrative personnel by over 45 percent and destroyed part of the military stockpiles. But this gesture toward the Moldovan authorities did not mean that Moscow accepted Kishenev's conditions. In June, during the presidential meeting the head of the Russian state offered assistance in resolving the "Transnistrian problem" in return for promise of establishing permanent Russian military bases in the country. ${ }^{197}$ Yeltsin made similar offer to the authorities of Azerbaijan, Georgia and Armenia ${ }^{198}$. At this time, the Duma was not indifferent to the presidential arrangements. On November 17, 1994 the Congress of People's Deputies on the initiative of radical communists and nationalists (especially Vladimir Zirinovsky) passed a resolution proclaiming Moldova „a strategic sphere of Russian interests.“ This controversial decision was an answer to Moldova's accession to the Council of Europe on July 13, 1995 and the "Partnership of Peace" which was a program of North Atlantic Treaty Organization aimed at creating trust between NATO and other states in Europe.

The real shift in Russian foreign policy toward the "Near Abroad" came with the replacement of Minister Kozyrev by the Yevgeny Primakov. Although the new Minister was a proponent of protecting the Russian national interest in the region and strongly opposed NATO's expansion into the "Near Abroad", he was also an ardent supporter of using more diplomatic methods to advance national security. ${ }^{199}$ According to the International Crisis Group report, Moscow "became less willing to bear the primary costs of CIS reintegration and pushed this to occur at different speeds within core of willing states, including via the Custom Union (Russia,

\footnotetext{
${ }^{197}$ Sowińska-Krupka, Mołdawia 1994-1995,p.175.

${ }^{198}$ Ibid.

199 Jakub Godzimirski, Russian National Security Concept 1997 and 2000: A Comperative Analisis (London: European Security, Vol.9, 2000), p.80-82.
} 
Belarus, Kazakhstan, Kyrgyzstan and later Tajikistan) and the Russian-Belarus Union."200 The warming-up in Russia-Moldovan relations was also rooted in the outcome of the presidential elections in Moldova on November 31, 1996. In the second round of presidential elections the current President Mircea Snegur was defeated by the former head of the Agrarian Democratic Party and the speaker of Moldovan parliament, Petru Lucinschi. The newly elected President was very well known for his pro-Russian views and immediately after his victory the analysts in Moscow anticipated that " Lucinschi's victory could pave the way for the settlement of a secessionist rebellion by ethnic Russians in Moldova's industrial Dniester region.”201

Thus in the middle of the year the Russian Foreign Minister initiated quadripartite talks, with the representatives of Russia, Moldova, OSCE and Ukraine, on the memorandum entitled “ Bases for Normalization of relations between the Republic of Moldova and DMR."202 The very short document, (only two pages long), contained almost all the previous arrangements regarding the peaceful settlement of the Transnistrian conflict. Yet, the sides could not agree on the final status of the breakaway region and the final draft of the agreement assumed that the parties "continue the establishment between them of state-legal relations." "203 Although the Normalization Act did not initiate the establishment of the new sovereign republic of Transnistria it allowed it to have some attributes of an independent state. For, example, in accordance with the Act Transnistria was able to conduct of its own foreign policy. Moreover the act introduced the concept of " common state" which suggested the formation of the Moldovan Confederation with the independent entities within. Still performing his duties Snegur did not agree with the interpretation of the Act and did not sign the memorandum. Later, during the presidential

\footnotetext{
${ }^{200}$ B.a., Moldova: Regional Tensions over Transdniestria ...,p. 5.

${ }^{201}$ B.a., Pro-Russian Wins Moldova Presidency, The Los Angeles Times, December 3 2011, access online, http://articles.latimes.com/1996-12-03/news/mn-5297 1 moldova-presidency

${ }^{202}$ B.a., Moldova: Regional Tensions over Transdniestria..., p. 6.

${ }^{203}$ Roper, Regionalism in Moldova, The Case of Transdniestira..., p.12.
} 
elections the matter of the Normalization Agreement became an important issue. The Communist and pro-Russian candidate Lucinschi claimed that Snegur did not sign the Act because of the pressure from the government in Bucharest that wanted to maintain the Transnistrian crisis as long as possible to set Kishinev against the Russian authorities. His view on that matter was confirmed during the Lucinschi's October visit in Moscow. Through at that time only a presidential candidate, he pledged that during his presidency Moldovan-Russian relations would be of highest priority. ${ }^{204}$ However, after a couple of weeks it turned out that Snegur was not the only one who did not eventually agree on the content of memorandum. Yeltsin in the face of the upcoming presidential elections also did not support the arrangement included in the Normalization Act. He wanted to please hardline communists and nationalists opposing any concessions regarding status of the DMR and presence of the Russian troops in Moldova. ${ }^{205}$

Russian-Moldovan cooperation over the next three years revolved around finding conflict resolution. In the middle of 1997 newly elected President Lucinschi and the head of Transnistria worked up a special annex to the 1996 memorandum that elaborated on all of the disputed points. ${ }^{206}$ On May 8,1996 , the representatives of the breakaway region and Moldova signed in Moscow the annex to the memorandum and the agreement itself under the auspices of Russian and Ukrainian governments. With the signing of the Normalization Act, "newspapers and wire services immediately reported that the Transnistrian conflict had been resolved."207 Unfortunately, that was not entirely true. In reality the memorandum did not resolve any of the most controversial issues. For example, the document did not resolve either the presence of Russian troops or the final status of the province. Both sides were only obligated to continue the

\footnotetext{
${ }^{204}$ Alicja Sowińska-Krupka, Mołdawia 1996 (Warszawa: Rocznik Europy Środkowo-Wschodniej, 1997) , p.156.

${ }^{205}$ Ibid.

${ }^{206}$ Roper, Regionalism in Moldova, The Case of Transdniestira..., p.113.

${ }^{207}$ King, The Moldovans. Romania..., p.203.
} 
negotiations on a peaceful resolution within " the structure of one consolidated state.",208

At the same time the Russian authorities noticed that Moldova had retired from active participation in CIS activities, especially regarding military cooperation. Further Moscow was alarmed by the news that post-Soviet countries, Azerbaijan, Georgia, Ukraine and Moldova had met in Strasbourg to discuss the foundation of a new Organization for Democracy and Economic Development (GUAM). ${ }^{209}$ Although the official goal of establishing of organization was to find "solutions for mainly two problems that were not tackled properly within the existing organization where all four countries were members - in the CIS:(..) cooperation on regional security and cooperation on energy", GUAM was seen as a way of countering Moscow's influence in the region. ${ }^{210}$ Yeltsin not only worried that Russia would lose its dominant position in the area but was mostly afraid of American influence over " the Near Abroad" as the GUAM's founding was immediately supported by the United States government. In spite of the Russian deputy foreign Minister assurances that "there is no anti-Russian factor" in GUAM, the Russian president in order to improve Moldova Russia relations paid an unofficial visit to Kishinev. Allegedly during that meeting Yeltsin made Lucinschi an offer that in return for a reassurance that Moldova would not turn its back on Russia, the Kremlin might consider the withdrawal of the Russian Army from Transnistria. Unfortunately, taking under consideration the fact that the status of the Army did not change in any way, one can assume that presidents did not come to an agreement.

\footnotetext{
208 Jerzy Jackowicz, Mołdawia 1997-1998, (Warszawa” Rocznik Europy Środkowo-Wschodniej, 1999$)$,p.156.

${ }^{209}$ Lubov Andeevna Atorina, Specyfika Otnashenii Rossii i Stran ( Moscow: MGU, 2010), p.21.

210 Vlad Spanu, GUAM: Background, Organization's future and Ukraine's role, Politcom, access online 16 October 2012, http://politicom.moldova.org/news/guam-background-organizations-future-and-ukraines-role-157816-eng.html
} 


\section{Economic Crisis}

In 1998, as a consequence of the fast deteriorating economic situation in Russia, for the first time the governments in Moscow and Kishinev focused more on the economic issues in interstate relations than on resolving the Dniestrian deadlock. Trade between the countries had been regulated by the agreements signed during the Soviet period and the only time it had been disturbed was by the temporary export berriers imposed by Russians in order to influence the Moldovan policy-making process.

Meanwhile, in Russia the economy suffered from declining productivity, an artificially high fixed exchange rate between the ruble and foreign currencies, and an enormous fiscal deficit. ${ }^{211}$ Consequently, at the beginning of the year, nflation reached 84 percent, the biggest banks were being closed down and the government was forced to pay millions of rubles to settle with striking miners. In turn, the on-going economic crisis in Russia greatly influenced the already severe economic situation in Bessarabia. Since Moldova's declaration of independence in 1991, Russia had been the main investor in Moldova and the main supplier of the most strategic recourses like energy, oil, gas and other raw materials. ${ }^{212}$ Moreover, at that time, Russia accounted for "around 40 percent of the Moldova's export and till the outbreak of the crisis the reciprocal trade was growing". 213

In the face of the growing economic crisis in March 1998 Russia decided to take advantage of Moldova's dependence on Russian resources and forced the weaker partner to sign

\footnotetext{
${ }^{211}$ Homi Kharas, Brian Pinto, and Sergei Ulatov, An Analysis of Russia's 1998 Meltdown: Fundamentals and Market Signals (Washington : Brookings Papers on Economic Activity, 2001).

${ }^{212}$ Ellen Akerman, Implications of the Russia's foreign security policy on Moldova (Aberdeen: Scotish Centre for International Security, 2003), p.2.

${ }^{213}$ Ibid.
} 
the bilateral "Treaty on Friendship and Cooperation between the Russian Federation (RF) and the Republic of Moldova" that was very unfavorable for Kishinev. ${ }^{214}$ The agreement established the framework for Russian-Moldovan trade relations for the next ten years and set gas prices on a much higher level than the prices imposed on other post-Soviet states. For example, when Moldova had to pay 80 dollars per cubic meters for imported gas from the Federation, Belarus and Armenia paid only half of that. ${ }^{215}$ Due to the ridiculously high prices for the gas provided by the Russian gas monopoly, Gazprom, the republic's energy debt to Russia amounted to some 215 million dollars, or roughly 11 percent of Moldova's GDP. ${ }^{216}$ Kishinev's inability to pay for the gas deliveries forced Russia to halve the supply on July, 1, 1998. When Gazprom threatened a complete cutoff in August Moldova "agreed to transfer to Gazprom 90 million dollars in government bonds, with an annual interest rate of 7.5 percent, by the end of 1999." ${ }^{217}$ To be able to pay off the Gazprom debt the Moldovan leadership decided to introduce the system of "temporary power cuts" till the end of the year. This decision aroused much controversy among the Moldovan populations, as around half of the Gazprom debt was DMR's share. Yet, Kishinev was reluctant to let Tiraspol accept responsibility for its share of the debt to Gazprom, "viewing this as a further step in recognizing Transnistria's sovereignty.",218

The economic turmoil in both countries did not obstruct moving to the next stage of the Transnistrian conflict resolution. "With the active support of Russian Prime Minister Victor Chernomyrdin and Ukrainian President Leonid Kuchma Lucinschi and Smirnof concluded an agreement in Odessa in March 1998 that called for a reduction in the number of peacekeeping

\footnotetext{
214 Jackowicz, Moldawia 1997-1999..., p.153.

${ }^{215}$ Vlad Spanu, Why is Moldova a Poor and Economically Volatile (Waschington DC: Moldova Foundation, 2004).

216 "Moldova: Economic Trends", Quarterly Issue, January-March 1998 (Brussels: European Commission, 1998) , p.112, cited in: King, The Moldovans. Romania..., p.203.

${ }^{217}$ Quinlan, Moldova under Lucinschi, ..... p.88.

${ }^{218}$ Quinlan, Moldova under Lucinschi, ..... p.88.
} 
forces and the re-building of the bridges that were destroyed or damaged during the fighting in 1992 and 1993."219 Additionally, at this meeting the Russian Defense Minister, Igor Sergeev, made the removal of the Russian troops one of the conditions to the accomplishment of a final settlement of the Dniestrian conflict.

However, at the end of the decade, Russian-Moldovan relations significantly deteriorated. Moldovan authorities expressed their dissatisfaction with the course of cooperation with Russia during the CIS meeting by stating a willingness of resigning from membership in the organization. At the same time it tried to develop closer relations with one of its neighbors Romania. In order to do so the representatives of both countries met in Bucharest to discuss the extension of economic cooperation. There were two main reasons why Moldova stopped considering Russia as its most important partner. First of all, Moldova was tired of the endless talks and negotiations on withdrawal of Russian forces from DMR without any visible results. Moldovan authorities eventually understood that this decision was being constantly postponed only in order to retain decisive influence over the weaker country and did not really depend on the settlement of the Transnistrian conflict. Secondly, the consequences of the Russian crisis helped them to realize that the Moldovan economic situation was completely dependent on Russia's policy. Therefore, when Gazprom periodically reduced deliveries and threatened on occasion to cut off supplies entirely the Moldovan leadership started to look for international partners in the West.

The shift in the Moldovan attitude toward its major partner was also noticed by the Russian authorities. Firstly Moscow attempted to threaten the leaders in Kishinev by adopting the resolution in March proclaiming Transnistira "sphere of the Russian strategic interest.",220

\footnotetext{
${ }^{219}$ Roper, Regionalism in Moldova, The Case of Transdniestira..., p.113.

${ }^{220}$ Alicja Sowińska-Krupka, Mołdawia 1999 (Warszawa” Rocznik Europy Środkowo-Wschodniej, 2000) , p. 202.
} 
When this strategy did not bring the expected results, the Kremlin decided to implement the more diplomatic "Plan B." Namely, in November 1999 at the OSCE summit in Istanbul Russia eventually agreed on a declaration to remove all the army forces from Moldovan Republic by the end of 2002. ${ }^{221}$ Yeltsin also stated that all categories of arms and equipment would not be transferred to the Transnistrian Guard but were to be destroyed or withdrawn by the end of 2001 . It is important to note that, unlike the previous 1994 declaration on removal of the $14^{\text {th }}$ Army, this time the agreement was reached without any conditions and without any linkage to resolving Transnistria's status. ${ }^{222}$ Unfortunately that was the only difference between those two agreements. Similarly to the previous declaration, the Istanbul settlement did not resolve the issue and as it will be presented in the next chapter the presence of the Russian army would also be the main issue in the Russian-Moldovan relations in the XXI century.

Nevertheless, by the end of the 1990s, the size of the Russian troops decreased considerably, from 9250 in 1992 to 2600 in 1999. Also significant amount of military equipment was destroyed. ${ }^{223}$ Moreover, under the new Commander Evnevich the forces played a more conciliatory role and there was no more rhetoric about Moldovan fascists or orchestrated genocide, as occurred under the command of General Lebied. ${ }^{224}$ According to Charles King, these developments were consequence of Moscow's growing dissatisfaction with tragic economic situation in DMR and enormous Gazprom debt. Moreover, the Kremlin was unsatisfied with the fact that Trasnistria seemed to be an creation that mostly served the economic interests of its leaders. ${ }^{225}$ Not without effect was the strong support of the DMR leadership for the Yeltsin opposition during the 1991 and 1993 coups in Moscow. Therefore at the end of the decade the

${ }^{221}$ Roper, Regionalism in Moldova, The Case of Transdniestira..., p.113.

${ }^{222}$ Ibid.

${ }^{223}$ B.a., Moldova: Regional Tensions over Transdniestria..., p.5.

${ }^{224}$ King ,The Moldovans. Romania ..., p.203.

${ }^{225}$ King ,The Moldovans. Romania ..., p.203. 
Yeltsin leadership had little reason to associate itself with the Dniestrian authorities and deteriorate the relation with Moldova by providing assistance to the rebellious region.

By the late 1990s the political atmosphere in Kishinev also changed, which brought a new perspective to Russian-Moldovan relations in the XXI century. The Moldovan population was no longer so optimistic about the formation of the new state and no one spoke about possible reunification with Romania. Moreover the newly elected President Lucinschi was a very fervent proponent of close cooperation with Federation and opposed any symptoms of nationalism in Moldovan politics. ${ }^{226}$ All of this set up excellent conditions for the final resolution of Transnistrian conflict and for intensifying cooperation with Russia.

${ }^{226}$ Ibid. 


\section{Chapter III}

\section{The Voronin Era. Moldovan-Russian Relations in the}

\section{First Decade of XXI Century}

\section{Putin's rise to Power}

Unexpectedly, the year 2000 was marked by the significant changes on the Russian political scene and consequently a shift in the Kremlin's foreign policy. On 31 December Boris Yeltsin made a New Year's address live on the Russian television in which he resigned as a Russian president and nominated Vladimir Putin, who was supposed to serve as an acting president up until the presidential elections due to take place on 26 March $2000 .{ }^{227}$ President Yeltsin had taken the entire world by surprise. He had not only resigned half a year before presidential elections but he nominated a little- known high-ranking KGB officer a new head of a state. Yeltsin praised Putin as the best man to replace him: "Why hold on to power for another six months, when the country has a strong person, fit to be president, with whom practically all Russians link their hopes for the future today? Why should I stand in his way? Why wait for another six months?"228 In the March election the incumbent Putin won in the first round with about 53 percent of all votes. One of the reasons why he gained such a political popularity and

\footnotetext{
${ }^{227}$ B.a., 1999: Putin takes over as Yeltsin resigns, BBC News, accessed online 15 June 2012, http://news.bbc.co.uk/onthisday/hi/dates/stories/december/31/newsid 4102000/4102107.stm

${ }^{228}$ B.a., Context of 'December 31, 1999: Yeltsin Resigns; Putin Now Acting President of Russia, History Commons, accessed online 21 July 2012, http://www.historycommons.org/context.jsp?item=a123199yeltsinresignation
} 
won over his greatest opponent Gennady Zyuganov was his hard line stance on the war in Chechnya. Just a month before the election Russian troops captured Grozny, the capital of the breakaway region, and thus ended over five-months of fighting. This was widely perceived to be the first political victory of Putin.

Right after the appointment of the new President, Putin moved to reforming the Russian policy-making organs as well as reevaluating the policy toward both, the West and "the Near Abroad". He decided to create the new strategic concept, placing "the CIS member states on the top of Russian foreign policy priorities, seeing them as strategic partners and desiring the integration of the CIS with Russia, in particular in the economic and security spheres." 229 Therefore the Republic of Moldova not only remained in the sphere of the Russian vital interests but also became an important international partner.

Putin's early presidency was characterized by political pragmatism. Moscow resigned from the policy of the full CIS integration in favor of securing the bilateral agreements in order to ensure its influence. ${ }^{230}$ By ensuring influence in Moldova Russia hoped to slow down Kishinev's integration process with the European Union and NATO. Therefore in June 2000 Putin's government established special committee headed by Foreign Minister, Yevgeny Primakov, to coordinate the future negotiations of Transnistrian conflict. One month later the committee presented a draft agreement on the DMR problem with the proposal of creating a Moldovan confederation. According to the proposal the Transnistrian Republic would have had an equal status with Moldova within the confederation in order to allow it to greatly influence Moldovan policy-making. This proposition served perfectly Russian interest because enabled Transniestira

\footnotetext{
${ }^{229}$ B.a., New Russian Policy Concept of June 2000 in: Ella Akerman, Implications of Russia's foreign and Security Policy on Moldova (Aberdeen: Scottish Center for International, 2008), p.5.

${ }^{230}$ B.a., Moldova: Regional Tensions over Transdniestria (Brussels: International Crisis Group, European Report nr. 157), p.6.
} 
to have a decisive vote in Kishinev guaranteed a continuing, and direct, Russian influence in Bessarabian politics. "Under this draft each side would be allowed to maintain its own constitution, legislative, executive, and judicial bodies, flag, coat of arms, and national anthem.“'231 Additionally, the Russian Foreign Minister offered to increase the number of Russian peacekeepers to 26000 (with simultaneous withdrawal of the OGRF troops), allow Ukrainian and OSCE observers but, on no condition, to involve non-CIS troops in the mission. ${ }^{232}$ However, both Moldovan and Transnistrian authorities opposed the implementation of the agreement. The DMR leadership did not want to accept the removal of any Russian troops from the region while Moldova did not want to allow the "confederalization" of the country as it would in fact mean the formation of the independent Transnistrian state.

Meanwhile Moldova itself was rocked by the serious political crisis that lasted from the end of 1999 till the parliamentary elections in 2001. The political gridlock was rooted in President Lucinschi's efforts to strengthen his powers by transforming the country into the presidential republic. By calling for the referendum on the amendment to the constitution Lucinschi commenced a long-lasting war with the Moldovan Parliament. The parliamentary leaders, both non-Communists from the Alliance for Democracy and Reforms and Communists from The Communist Party of the Republic of Moldova (PCRM), charged the current head of state with responsibility for destabilizing the country, acting for his own interests, and "dictatorial ambitions". The parliament started to debate a reform of the constitution aimed at weakening the presidential power and unexpectedly, on 5 July 2000, the lower house passed three constitutional amendments strengthening the power of the parliament and making Moldova a parliamentary

\footnotetext{
${ }^{231}$ Quinlan, Moldova under Lucinschi..., p.95.

${ }^{232}$ Ibid.
} 
republic in line with a "Westernized model". ${ }^{233}$ Under the new law the new president would be elected by the three-fifths of the vote in the lower house, not in direct elections. The communist representatives in the parliament who voted in favor of electing the president by parliament asserted that this change in the constitution would lead the country " in the direction of a true parliamentary republic and forestall the creation of a semi-autocratic regime. ${ }^{, 234}$ In practice, the changes in the constitution allowed the major parties to elect as president its own leaders and thus in the next parliamentary elections of 2001 to take over important institutions.

The political crisis and the upcoming parliamentary elections proved to be a great opportunity for the increasingly popular, Communist and pro-Russian Party, and its leader Vladimir Voronin. That, in turn, was a great chance for Russian authorities to maintain influence over Moldovan politics through a Communist politician loyal to Moscow. Indeed, during the election campaign in January 2001, Vladimir Voronin stressed the need for close cooperation with the Kremlin and the CIS member states and signaled his willingness to make the Russian language the second official language of the republic. ${ }^{235}$ The results of the parliamentary elections that were held on 25 February 2001 surprised everyone, even the Moldovans themselves. The Party of Communists of the Republic of Moldova won the elections with an overwhelming constitutional majority in the parliament and thus, gained control over the presidential elections. ${ }^{236}$ Hence, ten years after the dissolution of the Soviet Union and the announcement of the existence of an independent Moldovan state, a majority of Moldovan voters opted for home-coming to power of the main Communist leaders. According to Paul D. Quinlan, a specialist at the Davis Center for Russian and Eurasian Studies, the main catalysts of the

\footnotetext{
${ }^{233}$ Quinlan, Moldova under Lucinschi..., p.96.

${ }^{234}$ Kendra Lea Vessels, Why is Moldova a country: Russia's Continued Influence in the Near Abroad (Austin: Report of the University of Texas, 2011), p.51.

${ }^{235}$ B.a., Moldova: Regional Tensions over Transdniestria...,p. 7.

${ }^{236}$ B.a., Country Report Moldova, EIU, No. 1 2000, p.8.
} 
communists' victory in 2001 elections were "the seemingly inevitable plummeting of the economy and the resulting penurious living standards with little hope for a change."237 In early April, the newly elected lower house without any trouble selected the Communist leader Voronin as the new president of Moldova. The country became one of the few remaining Communist, proRussian states and henceforth Moscow had a good reason to expect close cooperation with Kishinev. ${ }^{238}$

\section{Moldovan Communists rise to power}

Some scholars argued that the victory of the Communists would not have been possible without strong Russian support and influence. ${ }^{239}$ How did Russia affect the Moldovan elections? One of the ways in which Russia could have had influenced the Moldovan voters was through the public media. In accordance with survey conducted by the Eurasia Foundation of European Integration, "when it comes to confidence in media, the majority of respondents -67.7 percent tended to have confidence in Russian TV channels." ${ }^{240}$ In that case more then a half of the population received information about Moldovan, Russian and global politics from Russian sources.

The efforts Russia put in order to influence the Moldovan elections should not be

\footnotetext{
${ }^{237}$ Paul D. Quinlan, Moldova under Lucinschi, The George Waschington University, accessed online 21 September 2012, http://www.gwu.edu/ ieresgwu/assets/docs/demokratizatsiya\%20archive/10-1 Quinlan.PDF, p.99.

${ }^{238}$ Riina Kaljurand, Russian Influence on Moldovan Politics during the Putin Era (2000-2008) (Tallin: International Centre for Deffence Studies, 2008), p.10.

${ }^{239}$ Matthew Crandall, Hierarchy in Moldova-Russia Relations: the Transnistrian Effect (Tallin: Studies of Transition States and Societies, Vol 4, 2008), p.8.

${ }^{240}$ Crandall, Hierarchy in Moldova-Russia Relations..., p.7.
} 
surprising, taking under consideration the profits Moscow gained with the triumph of Communists in Moldova. The victory of PCRM in the parliamentary elections and the selection of the first secretary of the Communist Party, Voronin, as head of the state offered the Kremlin a chance to pursue its own idea for resolving the Transniestrian conflict and to control the political decisions made in Kishinev. In early 2001 the new leadership declared that for now on Moldova would be a modern socialist country, “a European Cuba" and Voronin assured that the country's foreign policy would "undergo some modifications". What this meant in practice was turning toward the East. ${ }^{241}$ Indeed, already ten days after the elections Voronin went to Moscow in order to assured the Kremlin that "Russia has always been, is, and will be the strategic partner in all areas, including joint actions on the international stage." 242 During this visit Putin also stressed Russian willingness of the close cooperation by saying that both countries would "work to sustain their economic links in order to reach together the targets that Moldova has set for itself."243

In November 2001, just a few months after an appointment of the new president, the Russian-Moldovan Friendship and Co-operation Treaty was signed. This document provided the necessary framework for the bilateral relations and stipulated Moscow as the guarantor of Moldova's integrity. ${ }^{244}$ Moreover, under the Treaty's provisions Russia became the major mediator and coordinator in a political settlement of the Transnistrian conflict. The Treaty also provided for cooperation on tax, financial, monetary, trade, and customs policies. ${ }^{245}$ Yet

\footnotetext{
${ }^{241}$ Wesley Merle Shoemaker, Russia and the Commonwealth of Independent States (Harpers Ferry: Stryker-Post Publications, 2006), p.168.

${ }^{242}$ Bertil Nygren, The Rebuilding of the Greater Russia, Putin's Foreign Policy towards the CIS Countries (New York: Routledge, 2008), p.84.

${ }^{243}$ Ibid.

${ }^{244}$ Florian Kuchler, The Role of the European Union in Moldova Transnistrian Conflict (Stuttgard: Ibidem-Verlag, 2008), p.61.

${ }^{245}$ B.a., Moldova: Regional Tensions over Transdniestria..., p.7.
} 
according to Graeme P. Herd the whole treaty was not made fully public. ${ }^{246}$ The document showed that the Moldova's Gazprom debts, including the DMR's amount (around 1 billion dollars), would be paid by Kishinev. ${ }^{247}$ Even more importantly the Treaty included the provision that the Russian language would play an important role within Moldovan society and therefore Kuishinev would make an effort to provide all necessary conditions for the Russian language instruction in Moldovan primary and secondary schools. ${ }^{248}$ Additionally to the document described above the communist-dominated parliament has ratified by majority of votes the intergovernmental agreement on Russian-Moldovan military cooperation that had been signed already in 1997. The ratified document provided for cooperation in gathering information, exchange of visits and experience as well as conduct of joint research projects, exercises and exchange of cadets. ${ }^{249}$

As one can clearly see there had never been such a warm atmosphere in RussianMoldovan relations as after the victory of PCMR. In addition to the signed bilateral agreements the pro-Russian attitude of the Moldovan government was noticeable also in new legislation on domestic affairs passed by the lower house. In August the Communist leadership decided to introduce the Russian language as an obligatory subject in all Moldovan schools and to change the subject previously called "the History of Romanians" to "History of Moldova." 250 The Communists' stance on the language issue was expressed by Voronin during his second visit in Moscow when he said that he would prefer all Moldovans to speak Russian. ${ }^{251}$ This statement

\footnotetext{
${ }^{246}$ Graeme P. Herd, Moldova and the Dniestr Region: Contested Past, Frozen Present, Speculative Futures? (Surrey: Defense Academy of United Kingdom, 2005), p.19.

${ }^{247}$ Ibid.

${ }^{248}$ Bertil Nygren, The Rebuilding of the Greater Russia ..., p.84.

${ }^{249}$ B.a., Moldova's Parliament Ratifies Agreement On Military Cooperation With Russia, Pravda.ru, accessed 20 April 2012, http://english.pravda.ru/news/world/ussr/20-04-2001/40646-0/

${ }^{250}$ Alla Skvortova, Country Report Moldova, Center for Applied Policy Research at University of Munich, accessed online 12 September 2012, http://www.cap.lmu.de/download/2003/2003 Skvartova.pdf

${ }^{251}$ Bertil Nygren, The Rebuilding of the Greater Russia ..., p.85.
} 
and the new language law itself stirred up significant opposition among the non-communist politicians as well as ordinary Moldovan citizens. It was manifested by mass street rallies during which the protestors requested the dismissal of the Communist government and asked for the new parliamentary elections. ${ }^{252}$

Even though the economic and politician situation in Moldova was extremely tense the Communist leadership believed that the pro-Russian approach and the decisions associated with it would help to settle the Transniestrian problem and, even more importantly, lead to preferential treatment in Russia - Moldova trade. As presented in the previous chapter "Russia traditionally represented the largest market for Moldovan goods and at the same time the biggest, if not only, energy supplier." ${ }^{, 253}$ In 2000 Moldova's economic dependence on Russia even deepened as the reciprocal trade for the previous two years had increased nearly six times and was estimated at more than 534 million dollars in $2000 .^{254}$ Thus, in order to negotiate advantageous economic agreements at the end of 2001 year the Moldovan leadership announced willingness to join an economic union with Belarus and Russia. The Commonwealth of Belarus and Russia, as it was initially called, was created in April 1996 in order to provide a full political, economic, and social integration of the two countries. Kishinev's decision to join the economic structure of the organization would mean in practice a return to the situation from fifteen years earlier, when Moldova was still a part of the Soviet Union.

\footnotetext{
252 Ibid.

253 Skvortova, Country Report Moldova... .

${ }^{254}$ Ella Akerman, Implications of Russia's foreign and Security Policy on Moldova (Aberdeen: Scottish Center for International 2008), p.5.
} 


\section{A Great Disappointment}

In spite of the efforts Voronin and his government put into the strengthening of ties with Russia, nothing went the way the Communist had hoped. The signing of the Treaty of Friendship and Co-operation and the Moldovan proposal to join the economic union with Russia and Belarus did not encourage Moscow to provide substantial economic assistance to Moldova, especially when the prices for gas deliveries were concerned. During the meeting of Moldovan Prime Minister Vesile Tarlev and Russian Prime Minister Mikhail Kasianov at the beginning of 2002 the latter clearly stressed that Moscow was not willing to help Kishinev to its own disadvantage and was going to keep gas prices of the same level. ${ }^{255}$ The Prime Minister also stated that high level of taxes on imports of sugar, alcohol and tobacco would not change in the near future which, in turn, resulted in a drop of Moldova's sugar exports by over 90 percent. ${ }^{256}$ At the same time Russian politicians emphasized that that the volume of Russian investment in Bessarabia was systematically growing and the import of the Moldovan wine amounted to almost 80 percent of the total volume of the imported wine. ${ }^{257}$ However Kishinev was not satisfied with the results of talks and a few days latter Voronin renounced Moldova's intended integration with the BelarusRussian State Union by saying that Moldova had no interest in joining the organization. ${ }^{258}$

Similarly, Moscow did not meet the high expectations of Moldovan authorities regarding its role in the settlement of Transnistrian conflict. Voronin has hoped that the pro-Russian stance

\footnotetext{
${ }^{255}$ Alexander Isaev, Rossia - Moldova: Sozdany Predposylki dlia Razvitia Ekonomicheskikh Sviazei (Kishinev: NM, 22 November 2001).

${ }^{256}$ Skvortova, Country Report Moldova... .

257 Ibid.

${ }^{258}$ Lech Wojciechowski, "Mołdawia”in: Rocznik Europy Środkowo-Wschodniej 2001-2002 (Warsaw: ISP PAN , 2003) p.211.
} 
and the new policy of Communist government would convince Moscow to support Moldova in the clash with Smirnof and his entourage. It did not really happen. When during the talks on solving the conflict the DMR leadership refused to make any concessions in negotiations, Moldova was forced to walk out and apply necessary economic sanctions. Those sanctions included the introduction of the new custom stamps with the WTO standard's marks that were not provided to breakaway region. Thus Transnistria's exports came under Kishinev's control. ${ }^{259}$ At the same time Voronin asked for Russian support but Putin, although he refused to recognize the old Transnistrian seals, did not fully back up Voronin and kept subsidizing gas being sold to Smirnof government. Additionally, at the end of October 2002 the Speaker of Russian Duma, Gennady Selezniov, publicly announced that the Kremlin would not be able to meet the deadlines for withdrawing its troops from the region that were agreed on the OSCE summit in Istanbul in 1999. ${ }^{260}$ Instead Russia requested from the OSCE's an extension of the deadline to the end of 2003.

The course of events described above and the lack of economic privileges for Moldova in trade with Russia significantly souredrelation between the two states. Along with resigning from joining the State Union of Belarus and Russia, the Moldovan government slowly backed away from the concession on the Russian language. In March 2002 the Moldovan Constitutional Court ruled the new language laws unconstitutional and declared that the publication of official documents in Russian was against the state law. More importantly, the Moldovan leadership reevaluated its relations with the West and expressed its willingness to strengthen cooperation with European countries and Western international organizations like the European Union and NATO. At the end of 2002 the Moldovan Prime Minister Tarlev stressed that Moldova wished for deeper

\footnotetext{
${ }^{259}$ B.a., Moldova: Regional Tensions over Transdniestria..., p.8.

${ }^{260}$ Wojciechowski, "Mołdawia"in: Rocznik Europy Środkowo..., p.212.
} 
integration with the European structures. The Moldovan parliament also adopted "the program for the social and economic development of Moldova to 2005, which gave the highest priority to the country's participation in the European integration processes." ${ }^{261}$ Furthermore, in December 2002, Vladimir Voronin called into being the National Commission for European Integration that was responsible for elaborating the EU integration strategy and intensifying the co-operation between various government institutions in this area. ${ }^{262}$

\section{4. "The Kozak Memorandum"}

Is it fairly clear that the Moldovan Communist Party and its leader were caught trying to balance stronger tendencies toward European organization with a continued pro-Russian stance. Moscow was not indifferent to Moldova's increasing European aspirations. At the beginning of 2003 the General Staff in Moscow held back the planned withdrawal of the Russian troops from Transnistria, which surprised not only Moldova but all sides involved in the negotiations. In response to those developments Voronin rushed to Moscow in order to request the renewal of negotiations on the matter of Russian forces in the DMR and the final settlement of the conflict. After a visit to Moscow on February 9, 2003 the Moldovan president proposed the draft of the new constitution that would introduce the new Moldovan political identity characterized by a union of partially self-governing states that would, in turn, satisfy all of the interested sides DMR, Moldova and Russia. Greame P Herd, researcher of the Defense Academy of the United

\footnotetext{
${ }^{261}$ Jacek Wróbel, The European Union and Moldova (Warsaw: CES Studies, 2004), p.64.

${ }^{262}$ Wróbel, The European Union and Moldova (Warsaw: CES Studies, 2004), p.64.
} 
Kingdom, explained Voronin's move by saying that “This initiative was President Voronin's contribution to a political settlement based on federal principles and appears to operate on the logic of "You have the power, we have the control." ${ }^{263}$ In response Putin sent to Kishinev Dimitri Kozak, the deputy head of the presidential administration, as an advisor to consult in the preparation of the constitution's draft and prepare the special guideline of the basic principles for state structures that would lead the drafting. ${ }^{264}$ This special guideline, latter called Kozak Memorandum (Also Kozak Plan), turned out to be another bone of contention in the RussianMoldovan relations. In the summer of 2003 Putin's specialist without assistance from the OSCE co-mediators, commenced trilateral talks between Kishinev, Tiraspol and Moscow regarding the future status of the "common state". The main goal of the Russian diplomacy was to reach a constitutional agreement, under which the DMR would remain a separate federal entity within the greater Moldovan state, thus maintaining Moscow's influence in Moldovan domestic affairs and preventing its involvement in European structures. ${ }^{265}$ In July 2003 the head of the Russian Presidential administration asked Moldova to present the first draft of the constitution in order to included the Kremlin's amendments. Two months latter Kozak returned to Kishinev with an elaborated draft that included a proposal of creation of the asymmetrical federation (quasi confederation) with two separate entities, Moldova and Transnistria, that would have their own constitutions, executive, legislative and judicial bodies, budget, taxes and state property. ${ }^{266}$ Surprisingly the answer of Moldovan authorities was positive and it was Smirnof who did not accept Moscow's proposal. DMR authorities felt that this solution would not allow them eventual separation from Moldova and the proposed neutrality of the state would not guarantee the future

\footnotetext{
${ }^{263}$ Herd, Moldova and the Dniestr Region ..., p.7.

${ }^{264}$ B.a., Moldova: Regional Tensions over Transdniestria..., p.22.

${ }^{265}$ Achilles Skordas, Transniestria: Another Domino on Russia’s Periphery? (New Heven: Yale Journal pf International Affairs, 2005), p.35.

${ }^{266}$ B.a., Moldova: Regional Tensions over Transdniestria..., p.22.
} 
presence of the Russian army on Transniestrian territory. Under those circumstances Dimitri Kozak returned to Moscow without any signed documents. Yet, unexpectedly, Moscow decided to amend the elaborated memorandum. On November 14, 2003 Minister Kozak handed to Ambassador William Hill of the OSCE Mission in Kishinev the ready-made "Memorandum on the Basic Principles for the State Structure of the United State in Moldova" and thus made the document public. ${ }^{267}$ On the day later the memorandum was presented to the all concerned parties and on November 25 officially signed by the Russian President. ${ }^{268}$ The current plan established the asymmetrical federation that at this time would have consisted of three entities: historical Moldova with majority population of Moldovan decent, the Moldovan Dniestr Republic and Gagauzian Republic, all of which would have its own executive, legislative and judiciary bodies as well as separate budgets. Moreover there were supposed to be establish federal institutions that would correspond to the local ones. Even more importantly, according to the proposed draft, the Transnistrian minority would basically be given veto power vote in the two-chambered federal Parliament on most of the significant issues. ${ }^{269}$ For instance, in the federal 26-seat upper house the DMR would have 9 senators, Gagauzia 4 and Bessarabia 13, which would signified that in case of the voting on crucial issues historical Moldova would not be able to reach the required approval by 75 percent, even with the support of the Gagauzia's representatives. ${ }^{270}$ The DMR and Gagauzia would also have an large influence on the makeup of the federal government " as the prime minister would require upper house confirmation and the two first deputies would be

\footnotetext{
${ }^{267}$ John Lowenhardt, The OSCE, Moldova and Russian Diplomacy in 2003 (The Hague: Clingendael Institute,2004), p.5 .

${ }^{268}$ B.a., Memorandum ob Osnovnykh Principiakh Gosudarstvennogo Ustroistva Obedinionnego Gosudarstva, RIA Novosti, accessed online 17 November 2011, http://visualrian.ru/ru/site/video/news/

${ }^{269}$ Marius Vahl, Michael Emerson, Moldova and the Transnistrian Conflict (Flesburg: Journal of Ethno Politics and Minorities in Europe, 2004), No.1 2004), p.12.

${ }^{270}$ Lowenhardt, The OSCE, Moldova and Russian Diplomacy in $2003 \ldots$, p.6.
} 
appointed with agreement of the two regional parliaments. ${ }^{271}$ But this was not the end of the provisions threatening the Moldovan position within the planned federation. The most important problems, the stationing of the Russian troops in DMW and the status of Russian language, were also settled by Kozak in favor of the separatist territory. Although initially the Memorandum included the provision that the Federation of Moldova would be a neutral, demilitarized country and would not maintain its own army, the document did not refer to the presence of the Russian army. The day after releasing the document Smirnof demanded the inclusion to the memorandum that Russian would be the state official language of the entire territory and that the Russian peacekeeping forces would be present in DMR for the next 30 years. ${ }^{272}$ Voronin, who at that time was sure that his Russian stance would lead to the replacement of the current Transnistrian leadership, was taken by surprise by the Russian answers to Smirnof's demands. ${ }^{273}$ The Russian Defense Minister, Sergei Ivanov, during the official meeting with DMR leader guaranteed that Russian troops would be present up until the 2024 and that the next draft of the memorandum would include a provision on the Russian language to become the second official language in the future Moldovan state. ${ }^{274}$

The international players, so far actively involved in the peace process in the region, were deeply surprised by such a trajectory. They were not only excluded from the work on the draft but first and foremost, they were not even informed that such negotiations were taking place. The OSCE and Ukrainian co-mediators eventually found out about the three-sided consultations on the new constitutions from the DMR leadership that, unsatisfied with the current draft, purposely leaked the information to the OSCE representatives and insisted on commencing five-sided talks

\footnotetext{
${ }^{271}$ B.a., Moldova: Regional Tensions over Transdniestria..., 22.

${ }^{272}$ Ibid., p.25.

${ }^{273}$ B.a., Pochemu ne byt podpisan Memorandum po pridnestrovskomu uregulowaniu- Interview with Vladimir Voronin (Kishinev: Logos Pres, 28 November 2003).

${ }^{274}$ Lowenhardt, The OSCE, Moldova and Russian Diplomacy in 2003 ..., p.6.
} 
as in previous years. ${ }^{275}$ After the news on the secret talks reached the co-mediators they immediately asked to join the negotiations and to be allowed to access the prevailing results of negotiations. Moscow firmly refused. This and the fact that the Russian proposal included many provisions unacceptable for the government in Kishinev led to the rise of a strong opposition to the Kozak Memorandum from the European, OSCE and American administrations. They argued that under such conditions the DMR would have a blocking majority in the federal government while in the regional institutions would exercise a total willfulness. Thus, right after the document was made public the representatives of the various Western countries and organizations scheduled urgent meetings with the Moldovan president who, at that time still had a decisive power within the Moldovan state.

At first Kishinev's reaction to the proposed draft was positive. Voronin argued that although some regulations would have to be reevaluated the benefits of the incorporated new constitution absolutely overweighted the chance of a flare-up of conflict in the region. ${ }^{276}$ The Russian plan of the "common state" was actually initiated by the Moldovan president who dreamed to be the one bringing peace to the region and thus he wanted to carry through the negotiations at all costs. ${ }^{277}$ Nevertheless the President immediately found himself under the domestic and foreign pressure not to sign the proposed draft. At the beginning of November 2003 the chairman of OSCE, Jaap de Hoop Scheffer, met with Voronin and strongly encouraged the Moldovan politician to reject the "asymmetrical federation' plan pointing out that the Russian proposal was an attempt "to impose a distorted political and economic system on a fragmented

\footnotetext{
${ }^{275}$ B.a., Moldova: Regional Tensions over Transdniestria..., p.23.

${ }^{276}$ B.a., Moldova: Regional Tensions over Transdniestria..., p. 23.

${ }^{277}$ Lech Wojciechowski, "Mołdawia “ in: Rocznik Europy Srodkowo-Wschodniej 2003 (Warsaw: ISP PAN, 2004), p. 160 .
} 
country" in order to cement Russian domination of Moldova. ${ }^{278}$ Additionally, almost all of the members of NATO and EU as well as United States rejected the plan by stating that the implemented new constitution would prevent Moldova from cooperating independently with Western states and endangered the possibility for the country to ever become the member of the European Union. $^{279}$

Eventually, Voronin backed away from the agreement at the last minute. The plan was due to be signed on November 25, 2003. Minister Kozak arrived in the Moldovan capital a day earlier for the ceremony but President Voronin called off the meeting a couple of hours before its planned commencement. What made Vornonin decide to reject the plan? Opinions are divided. ${ }^{280}$ In numerous interviews he claimed that the reason he did not accept the proposal was that the settlement allowed Russian troops to be stationed in the Republic for next 20 years. ${ }^{281}$ However, Matthew Crandall in his article, "Hierarchy in Moldova-Russia Relations: The Transnistrian Effect" argued that "given the fact that Voronin initialed the agreement previously, it is plausible that without the fierce international opposition an agreement would have been reached" and Kishinev was disposed to accept Russian domination. ${ }^{282}$ John Lowenhardt from the Clindael Institute shared this view and claimed that the pressure from EU, USA and OSCE and the fear of the repetition of the "Georgian scenario" had play the major role in Voronin's decision. ${ }^{283}$

\footnotetext{
278 Skordas, Transniestria: Another Domino on Russia's Periphery?..., p.35.

279 Ibid.

${ }^{280}$ Lowenhardt, The OSCE, Moldova and Russian Diplomacy in 2003..., p.7.

${ }^{281}$ Nygren, The Rebuilding of Greater Russia..., p.131.

282 Crandall, Hierarchy in Moldova-Russia Relations: the Transnistrian ..., p.5.

${ }^{283}$ South Ossetia, an separatist region in Georgia has first proclaimed its independence in 1989. Backed by the Russia it decided to unite with North Ossetia, which belonged to the Russian Federeation. Tibilisi refused to recognize the Ossetian government, which lead between 1991 - 1992 to the Ossetian War. Since than the territory is controled by the Ossetain government, unrecognized by interational community, but strongly supposrted by the Russians; Lowenhardt, The OSCE, Moldova and Russian Diplomacy in $2003 . . .$, p.7.
} 


\section{The Diplomatic Downturn}

Regardless of the reasons, the consequences of that decision were easy to predict. Russia failed to meet the deadline for withdrawing its troops from DMR, which had been settled earlier during the 2002 OSCE meeting. The Transnistrian leaders at first did not want to accept Moldovan rejection of the plan and stated that they "do not renounce the Kozak Memorandum and are ready to sign it even tomorrow."284 Therefore, in January 2004, the three sides of the negotiations, this time along with the representatives of OSCE and Ukraine, met in Sofia in order to work on amendments to the current proposal. Moldovan experts presented the mediators with the new draft called "Declaration of the basic principles of a State Structure of the Republic of Moldova." that significantly decreased the Transniestrian stranglehold on the federation's politics while at the same time continued to provide it with a blocking majority in the Federation's upper house. ${ }^{285}$ However, Smirnof insisted on signing the Kozak Memorandum in its original version proposed by the Russian side. Tiraspol declared that if Kishinev refused to accept Kozak Memorandum, for reasons known only for Moldovan side, the DMR had its own draft of a new constitution that included the confederation of two states that would have equal status within the country. ${ }^{286}$ This proposal meant de facto the end of the negotiations on "the asymmetrical federation" as none of the sides wanted to agree on this settlement.

Meanwhile Moscow had been showing its discontent with Moldova's attitude. Dimitrij Kozak accused Voronin of lack of political courage and being unreliable while Putin canceled

\footnotetext{
${ }^{284}$ Jan Maksymiuk, Analisis: Transnister wants Talks on 'Federal System'with Moldova, Radio Free Europe/Radio Liberty, accessed online 17 September 2012, http://www.rferl.org/featuresarticle/2004/09/53bc0d6b-d61b-49bb-8f7ae563715de8b9.html

${ }^{285}$ B.a., Moldova: Regional Tensions over Transdniestria..., p.26.

${ }^{286}$ B.a., Moldova: Regional Tensions over Transdniestria..., p.26.
} 
planed official visit to the Moldovan capital. ${ }^{287}$ The growing criticism from the OSCE and UE representatives regarding the presence of Russian troops on DMR territory just added fuel to the fire. Russian relations with both the western organizations as well as with Moldova, significantly worsened. On the one hand Foreign Minister Ivanov criticized the OSCE for undermining a potential settlement of the conflict and refused to continue five-sided negotiations. On the other hand in 2004 Moscow did not invite Kishinev to join the CIS Common Economic Area at the Yalta summit, which was a big surprise for the Moldovan government taking under consideration that it expressed a desire to join the project already in $2001 .^{288}$

Yet, the worst moment for the Russian-Moldovan relations came with the breaking off of the Tiraspol-Kishinev talks in July 2004. The heat-up in the conflict was due to the DMR's harassment of the Moldovan language school that used non-Cyrillic script. ${ }^{289}$ The authorities closed the schools, removed all the equipment and transferred all the students to Cyrillic-script schools in different towns by claiming that the Moldovan institutions violated Transnistrian law, which required schools to use Cyrillic alphabet. ${ }^{290}$ Additionally, within a few weeks, authorities in Tiraspol prohibited the Moldovan farmers from to access their fields in Transnistrian territory. ${ }^{291}$ Such an anti-Moldovan attitude raised an enormous objection in Kishinev. Yet the Kremlin, which was always very careful in backing any of sides, this time definitely supported Smirnoff. When Kishinev responded to the dispute with the suspension of the custom service to Transniestrian enterprises that were not officially registered in Kishinev and canceled all the privileges of DMR businesses, the Russian Foreign Ministry along with the DMR leader called

\footnotetext{
${ }^{287}$ Wojciechowski, "Mołdawia"..., p.160.

${ }^{288}$ B.a., Moldova: Regional Tensions over Transdniestria..., p.26.

${ }^{289}$ Herd, Moldova and the Dniestr Region: Contested Past..., p. 8.

${ }^{290}$ B.a., Moldova 2004 Country Report, US Department of State, accessed 28 June 2012, http://www.state.gov/j/drl/rls/hrrpt/2004/41697.htm

${ }^{291}$ Ibid.
} 
this measure an economic blockade. ${ }^{292}$ Moldova was clearly displeased. In December 2004, Moldovan Foreign Minister Andrei Stratan gave an interview to Latvian media where he stated that" 1500 Russian troops in Transnistria is a military occupation." 293 At the same time a similar statement was made by President Voronin himself who furthermore declared that from now on the main aim of Moldovan foreign policy was going to be the strengthening of co-operation with the EU that would enable future membership in the organization. Russia reacted immediately. At the end of 2004 the Russian Ambassador to Moldova, Nikolai Ryabov, explicitly threatened the Republic by saying that too close relations with European partners would have tragic consequences for the fate of the country. ${ }^{294}$

\section{Economic Blackmail}

Indeed, when Russia began to carry out its threat and imposed economic sanctions on Moldovan products, the country's economy significantly declined. Imposition of sanctions had already turned out to be an effective tool as in the case of forcing Moldova into the CIS in 1994 and thus became "an established instrument of the country's increasingly muscular foreign policy." ${ }^{295}$ In March 2005 the Russian Ambassador announced that "The Russian government is

\footnotetext{
${ }^{292}$ B.a., “ Moldovan-Dniester War Enters Second Day”, ProTV, in: Herd, Moldova and the Dniestr Region: Contested Past..., p.8.

${ }^{293}$ Kaljurand, Russian Influence on Moldovan Politics during the Putin Era ..., p.8. 294 , "Mołdawia 2004"..., p.198.

${ }^{295}$ Igor Torbakov, Will Economic Sanctions Became a Legitimate Tool of Russian Roreign Policy?, Jemestown Fundation, accessed online 21 June 2012, http://www.jamestown.org/single/?no cache $=1 \&$ tx ttnews\%5Btt news $\% 5 \mathrm{D}=32316$
} 
weighing a variety of economic sanctions that could be imposed against Moldova in retaliation for what it considers unfriendly actions by the former Soviet republic." ${ }^{296}$ By unfriendly actions the politician meant Kishinev's political decisions as a result of the "school crisis". According to Interfax News, Moscow at first considered an embargo on alcohol and tabacco products, doubling the prices on imported energy supplies and introducing new regulations regarding entry visas for Moldovan citizens. ${ }^{297}$ In fact the Russian government on 18 April 2005 began with the embargo of Moldovan meat under a veil of opinion of the experts that "Moldovan meat unfits the qualitative veterinary and sanitary security standards compared with the meat of Ukraine, a country which holds modern meat processing facilities." 298 However, Moscow soon found out that this sanction would not hit the Moldovans as much as they previously expected because domestic demand for the product was growing constantly and the exported product covered the requisition of the domestic market. Therefore, Russia moved to the next stage of economic blockade and a month later it decided to hit the most important industries in Moldova, agricultural products and winemaking. Especially the banning of the export of the latter had a great impact on the condition of the Moldovan economy as in 2005 the wine export generated $25 \%$ of the countries GDP with Russia as the main export market accounting for almost $85 \%$ of the total export. ${ }^{299}$ The official reason for the ban was the lack of the quality control. At the beginning of December 2005 the exporters of the agricultural products and winemakers informed that As in result of the Russian boycott they had lost from $40 \%$ to $80 \%$ of their yearly incomes. ${ }^{300}$ However it was noteworthy after a while the embargo hit mostly the Russian entrepreneurs as

\footnotetext{
${ }^{296}$ B.a., Russia considers sanctions against Moldova, Ireland Online, accessed online 21 June 2012, http://www.freerepublic.com/focus/f-news/1365557/posts

${ }^{297}{ }^{297}$ B.a., Russia considers sanctions against... .

${ }^{298}$ Iurie Gotisan, Chisinau's economic dependence on Moscow, Associacion for Participatory Democracy, accessed online 21 June 2012, http://www.e-democracy.md/en/comments/socioeconomic/200505041/

${ }^{299}$ Russian trade sanctions against Georgia, Moldova and Ukraine, Moldova.org, accessed online 19 June 2012 http://economie.moldova.org/news/russian-trade-sanctions-against-georgia-moldova-and-ukraine-12562-eng.html

${ }^{300}$ Lech Wojciechowski, "Mołdawia”in: Rocznik Europy Środkowo-Wschodniej (Warsaw: ISP PAN, 2006) , p.191.
} 
the winemaking industry was dominated by businessmen of Russian desent. Another outcome of the economic embargo, surely not intended by the Kremlin authorities, was strengthening business links between producers from Moldova and Romania.

That was not the end of the economic blackmail though. In Autumn 2005 Moscow pressured Kishinev by using what can be called the "energy arm" and informed Voronin that Kremlin was no longer going to subsidize Moldovan gas supplies and requested repayment of the energy debt. 301 "The current price of 80 dollars per 10000 cubic meters was well below the market value and Russia did not see the need to subsidize Moldovan energy." ${ }^{302}$ Kishinev, although well aware of the situation, was not able to pay back the debt, which by the way was a Transnistrian debt. ${ }^{303}$ Therefore Kremlin demanded the remining shares in Moldovagaz. Gazprom owned 50 percent of Moldovagaz, the only national gas operator in the Republic $35.33 \%$ of its shares was owned by Moldovan state, and $13.44 \%$ by the DMR. ${ }^{304}$ By taking over the company Moscow would eliminate possible transit blockades and would strengthen its energy supplies monopoly in Eastern Europe. Moreover at the end of 2005 Moscow announced the doubling of the gas price, which meant that in 2006 Moldova would have to pay 160 dollars for 1000 cubic meters - the highest sum among all CIS members. Finally, in order to show the seriousness of the Russian threat Moscow with the helping hand of the Transnistrian power station in Ciuciurgan suspended the gas supplies to Moldova for a short period of time.

Yet, the above-mentioned conflicts were not only the result of the failure of the Kozak memorandum and the DMR-Moldova dispute. They were also strictly related to Moscow's

\footnotetext{
${ }^{301}$ Gotisan, Chisinau's economic dependence on Moscow... .

${ }^{302}$ Crandall, Hierarchy in Moldova-Russia Relations..., p.11.

${ }^{303}$ In 2005 the Moldovan debt to Gazprom reached 600 million dollars, of which around 90\% belonged to Transnistria.

${ }^{304}$ B.a., Dividing up Moldovagaz and Moldova's gas debts, OSW, accessed online March 302012 , http://www.osw.waw.pl/en/publikacje/eastweek/2011-03-30/dividing-moldovagaz-and-moldova-s-gas-debts
} 
attempt to influence the outcome of the parliamentary elections in March 2005 and were an element of its greater political strategy. As presented earlier in their paper with the failure of the Russian proposal of the DMR-Moldova conflict settlement Vladimir Voronin automatically became in Moscow persona non grata. Thus in the forthcoming elections, Russia decided not to back the Moldovan Communist Party and instead supported the strongest opposition party. This decision surprised, to say the least, both the Moldovan and Russian politicians as the main opposition party, Democratic Moldova, was known to be dominated by nationalists with a strong anti-Russian stance. Moreover, the leaders of the opposition, Serafin Urekian, Nikolai Andronik and Dimitri Bragish, were so far presented mostly in the Russian press as lawbreakers involved in smuggling and other criminal activities. ${ }^{305}$ Yet, regardless the Russian support for the opposition KPM again won the parliamentary elections by taking $46 \%$ of the votes. Although this was not enough to be able to elect the new president on their own, the number of seats allowed the Communists to be able to easily form a coalition for the Presidential voting. ${ }^{306}$ The Democratic Moldova party (which due to the Moscow support suddenly started to be perceived as proRussian and anti-European) won only $28 \%$ of the votes and in fact did not have any real impact on law-making procedures in the Moldovan parliament. ${ }^{307}$

It is also worth noting that the day before the elections the Moldovan authorities, aware of the Russian attempts to affect the ballot, forbade around 100 Russian observers to enter the country. ${ }^{308}$ Additionally, on the day of the elections several persons of Russian descent were arrested and charged with spying. Consequently, the opposition backed by the Kremlin claimed

\footnotetext{
${ }^{305}$ Zurab Todua, Rasiia v Moldovii: Vernut' iniciatyvu, Rasiia v Globalnei Politike, No. 1 2007, accessed online 21 June 2012, http://www.globalaffairs.ru/number/n 8148

${ }^{306}$ B.a., Moldova Communists Stay in Power, BBC News, accessed online August 72012 , http://news.bbc.co.uk/2/hi/europe/4322617.stm

${ }^{307}$ B.a., Moldova Communists Stay in... .

${ }^{308}$ B.a., Moldova Communists Stay in... .
} 
the election fraud but International observers headed by OSCE representatives announced that the elections broadly met the democratic standards. ${ }^{309}$ This failure of the Russian meddling was confirmed couple of weeks later when Communist Party formed a coalition with the proRomanian Christian Democrats and easily elected Vladimir Voronin for his second term. Now the only question remained: Would the Moldovan leader continued his pro-European policy or will see the reconciliation Russian partners?

\section{East or West? Which Course to Choose?}

Right after the end of the negotiations on the "Kozak Memorandum" the answer was simple: Voronin administration had made European Union integration its foreign policy priority. This is not surprising, taking under consideration that with an upset Russia, strongly supporting Smirnof and applying economic sanctions, Western partners were the only choice Voronin actually had. The European Union welcomed the new pro-European stance and automatically became more involved in the situation in Moldova. Thus, at the beginning of 2005 Brussels initiated the signing of the EU Action Plan on Moldova, which contained the practical guidance for the development of EU-Moldova relations and determined the steps Kishinev had to take in order to enable the future accession. ${ }^{310}$ The Republic also signed the agreement of European Neighborhood Policy which, among other things, designated the EU to become a co-mediator in the Tiraspol-Kishinev negotiations. Since the change of course in Moldovan foreign policy,

\footnotetext{
${ }^{309}$ Ibid.

${ }^{310}$ Chrostopher Borgen, Thawing a Frozen Conflict: Legal Aspects of the Separatists Crisis in Moldova, The Associacion of the Bar of the City of New York, Vol. 61 (2006), p.22.
} 
Kishinev started also to closely cooperate with the USA. As a result, the U.S. representatives joined the five-sided talks on a resolution to the conflict, which now adopted the new form "5+2", with the two Western participants becoming official observers. ${ }^{311}$ In this new format the sides met three times but without any significant progress, the negotiations were suspended. Yet Voronin kept on developing friendly relations with the West, which was confirmed by the European Commission opening of an office in Kishinev, appointing Adriaan Jacobovits de Szeged as its head and finally devoting 9 million dollars for fighting the economic consequences caused by the Russian embargo. Simultaneously, on 19 May 2006 Moldovan authorities agreed to sign the "Individual Partnership Action Plan with NATO", showing their strong willingness to join the Western military alliance. At the same time the U.S. leaders declared that they were ready to take a part in the demilitarization of Transnistria. The warm-up of Moldovan relations with the West clearly indicated a shift in Kishinev's foreign policy. As Kaljurand puts it, "this was a clear message to Russia that Moldova had lost confidence in Russia and had taken determined steps towards Europe. ${ }^{312}$

The new orientation towards European integration was visible also in domestic affairs. At the end of 2005 the Moldovan parliament voted to request a total withdrawal of the Russian peacekeeping forces and ammunitions supplying them from DMR by December of $2006 .{ }^{313}$ The decision was backed up by the leaders in Washington who stated that if Russia would not withdraw its troops, the USA would not ratify an agreement on Conventional Forces in Europe (CFE) while GUAM stated officially that separatism in Eurasia had been aroused mostly by Russian manipulation. ${ }^{314}$ This just made Moscow's hackles rise. The Kremlin not only stated that

\footnotetext{
${ }^{311}$ Chrostopher Borgen, Thawing a Frozen Conflict: Legal..., p.22.

${ }^{312}$ Kaljurand, Russian Influence on Moldovan Politics during the Putin Era...,

${ }^{313}$ Borgen, Thawing a Frozen Conflict: Legal Aspects ..., p.23.

${ }^{314}$ Wojciechowski, "Mołdawia"in: Rocznik Europy..., p.191.
} 
it did not need to enter the CFE, but also the Foreign Policy Minister announced that the Russian army should stay in Transnistria even after the end of the conflict in the region. ${ }^{315}$ Further on March 2006 Moscow recalled its Ambassador in Kishinev for consultations. Even the later announcement by Vladimir Lupu, the speaker of Moldovan parliament, that Moldova would consider exiting the CIS, did not change the Russian's hard stance on the policy toward the weaker partner and therefore Voronin was forced to reconsider his attitude toward Kremlin.

Indeed, the Communist leaders did their best to avoid the announced increase of gas prices. Throughout the entire year 2006 Moldova negotiated with Russia and its President kept on traveling to Moscow for the closed-door talks. ${ }^{316}$ Allegedly the Moldovans offered the Kremlin great opportunities for the investment in the country, including taking part in the privatization process and purchase of the shares in Moldovagaz. The content of the negotiations was not released to the public, which understandably alarmed Moldovan public opinion. The rumors had it that Voronin had agreed to cede the Transnistrian shares in the gas operator but this was quickly denied by the Minister of Economy Valeriu Lazar. ${ }^{317}$ The talks on the gas prices lasted up until the end of the 2006 year when in December, finally, the sides reached the agreement which indicated that the gas price would be increased gradually from $160 \$$ per 1000 cubic mater to 300 dollars in $2011 .^{318}$ This agreement was considered a great victory for the Russian diplomacy. Moscow not only was going to received the demanded price for the energy supplies, but most of all it seemed as if it had succeeded in turning back Moldova from its pro-European course. This should not be considered a surprise. The increasingly weak Communist Party of Moldova did not have a choice but to reconsider the Western orientation and to find the way to somehow settle the

\footnotetext{
${ }^{315}$ Lech Wojciechowski, "Mołdawia in: Rocznik Europy Środkowo-Wschodniej 2006 (Warsaw: ISP PAN, 2007), p.201.

${ }^{316}$ Wojciechowski, "Mołdawia...", p.201.

${ }^{317}$ Wojciechowski, "Mołdawia...", p.201.

${ }^{318}$ Ibid.
} 
recent conflict with Russia and thus regain the support on the domestic scene. Moreover, Moldova's location on the geopolitical map and lack of the alternatives in the energy dispute left the authorities in Kishinev without much of a choice. Not without fault was the European Union. Throughout the entire 2004-2006 periods Europe seemed not to notice the upcoming energy crisis and focused on subsidizing the Moldovan agriculture sector, which was obviously much easier than for example subsidizing the energy supplies. It might had seemed that the European member-states were hesitant whether to fully involve themselves in Moldovan affairs and as a result expose themselves to Russian political anger. ${ }^{319}$ In this case Kishinev was actually left out by its Western partners and therefore forced to look for a settlement with Gazprom.

\section{Pleasing Russia}

Indeed, the beginning of 2007 clearly showed that Moldova had forgotten about its European ambitions. The Moldovan government officially announced that as a consequence of the Russian-Moldovan settlement on energy supplies, Voronin had agreed for Gazprom to take over the Transnistrian shares in Moldovagaz, two thermal-electric power stations, and control over power lines exporting electricity to the Balkan states. ${ }^{320}$ Thereby Moscow received $63,4 \%$ of stocks in the biggest national gas operator in Moldova and was able to control the distribution network and the transit lines that embodied one of the major goals of Putin's new energy

\footnotetext{
${ }^{319}$ Kaljurand, Russian Influence on Moldovan Politics during the Putin Era...,

${ }^{320}$ B.a., Energetyczna gra: Ukraina, Motdawia i Białoruś między Unią a Rosja ( Warszawa: Fundacja im. Stefana Batorego, 2007), p.27.
} 
strategy. ${ }^{321}$ Additionally, in order to take full control over the Moldovan power system RAO, one of the largest Russian energy operators purchased the power plant "Jes" that was located on the Transnistrian territory. ${ }^{322}$

Apart from the negotiations regarding energy prices the Moldovan President conducted closed-door talks with Putin's administration concerning a new proposal for conflict resolution in Moldova. The news about the secret talks was first released by the well known political annalist of the Eastern Europe, Vladimir Socor in the webpage of the Jamestown Foundation. Namely, Socor claimed in the article that Voronin was ready for significant concessions that were unacceptable to any of the Western partners. ${ }^{323}$ This report earned the wrath of Moldovan public opinion. In response, 18 publicists, journalists, diplomats and politicians published an open letter calling President Voronin to reveal the outcome of the negotiations. ${ }^{324}$ Despite early assurances that such a meeting did not take place, the Presidential administration in April 2007 admitted that similar two-sided negotiations had commenced (during the talks Tiraspol was represented by Russian mediators). Among other decisions, the Moldovan chef of state allegedly agreed on the permanent presence of the Russian peacekeeping forces and the neutrality of the country, which, if applied, would once and for all prevent Kishinev from entering NATO.

The fact that that the Russian-Moldovan negotiations had actually taken place seemed to be confirmed by the subsequent political decisions taken by both sides. For instance, Kishinev's representatives refused to take part in the two GUAM summits, meetings of the organization that was perceived as the counterbalance to CIS. Further more, Moldovan authorities rewrote the proposal of the National Security Concept in 2007, removed all the articles that could upset

\footnotetext{
${ }^{321}$ Ibid.

${ }^{322}$ Ibid.

${ }^{323}$ Wojciechowski, "Mołdawia in: Rocznik Europy ..., p.250.

${ }^{324}$ Ibid., p.246.
} 
Moscow and thus proved that "the security policy had been adjusted to Russia's wishes." ${ }^{, 325}$ This gesture was in turn appreciated by the Kremlin and Moscow slowly started to lift the economic blockade. Firstly in April 2007 the Russian Ministry of Agriculture and Food Industry along with Federal Office of the Veterinary and Phytosanitary Inspection allowed Moldovan fruits and vegetables to return to the Russian market. ${ }^{326}$ However the winemaking enterprises patiently waited for the lifting of the wine embargo that was promised to happen already at the beginning of the year after the open threat that Kishinev would block Russia's planned entry to the World Trade Organization. The hard stance can be explained by the fact that the loses of the winemaking industry were overwhelming and hit the heart of the Moldovan economy. Radio Free Europe informed that "the Moldova-Vin export agency estimated the loss in sales for the wine industry at over $\$ 180$ million between March 2006 and January 2007... while Moldova's wine production dropped dramatically -8.96 dekaliters of bottled wine in 2006, a 63-percent decrease from 2005. ${ }^{327}$ Only in June 2007 did Voronin publically announced that the Kremlin had lifted the ban but even so only 20 out of 179 plants had authorization for exporting their products to the Russian Federation. ${ }^{328}$

The entire year 2008 was marked by the warm-up in Russian-Moldovan relations, especially regarding the settlement of the "frozen conflict". Voronin stated that during the CIS summit on February 29, 2008 Putin promised to reassume the "5+2" negotiations and furthermore that Russia had tentatively agreed to replace its troops in the DMR with civilian

\footnotetext{
${ }^{325}$ Igor Botan, Sankt-Petersburg CIS Summit, Democracy.md, accessed online June 11, 2012, http://www.edemocracy.md/en/monitoring/politics/comments/200806151/

${ }^{326}$ Lech Wojciechowski, "Mołdawia” in: Rocznik Europy Środkowo-Wschodniej 2007 (Warsaw: ISP PAN, 2008)248

${ }^{327}$ Ryan Kennedy, Moldova: Counting Losses As Russian Wine Ban Lingers, Radio Free Europe/Radio Liberty, accessed online 20 August 2012, http://www.rferl.org/content/article/1075697.html

${ }^{328}$ B.a., Moldovan Wine Back in Russia after Ban, Reuters, accessed online 12 June 2012, http://uk.reuters.com/article/2007/11/01/uk-moldova-russia-wine-idUKL0142079420071101
} 
missions of international observers. ${ }^{329}$ In order to commence the talks Moscow had to first convince Smirnof to sit at the table with USA, UE and Voronin himself. According to Kommiersant's report, Putin's administration de facto forced DMR leaders to meet with Heikki Talvetie, the Special Representative of the head of OSCE, during which Smirnof eventually agreed to negotiate with other co-mediators, at the same time signalizing, however that DMR would not give up its usual conditions. ${ }^{330}$ Even more important for Moldova was the statement of Russian Foreign Minister Grigori Karasin who assured that Russia would never use the so called "Kosovo procedure", which meant it would never recognize the Transnistrian independence. The Chairman of the Commission for CIS Co-operation later confirmed those assurances during his visits to Kishinev and Tiraspol where he tried to push DMR authorities to find the way to settle things with Voronin. ${ }^{331}$ Ostrovski mentioned at the same time that in order to maintain good relations with Moscow Voronin should reconsider Moldova’s membership in GUAM.

Russian-Moldovan co-operation was developing ideally. The closest associates of Moldovan President, Marka Tkaczuka, Minister for Reintegration Vasile Sovy, and Dmitri Socolana paid couple of visits to Russian officials to discuss the details of the settlement proposal. Additionally, Voronin during his meeting with Moscovite Patriarch Aleksei II talked about the "common future of both counties" and their "eternal friendship". ${ }^{332}$ One could easily assume that Voronin had returned to a Pro-Russian orientation with a relief. Indeed, some Moldovan politicians argued that the Moldovan President's heart always belonged to Moscow

\footnotetext{
${ }^{329}$ B.a., Rosja gotowa do kompromisu w sprawie Naddniestrza?, OSW, accessed online 12 September 2012, http://www.osw.waw.pl/pl/publikacje/tydzien-na-wschodzie/2008-03-05/rosja-gotowa-do-kompromisu-w-sprawienaddniestrza

${ }^{330}$ B.a., Rosja gotowa do kompromisu w sprawie Naddniestrza... .

${ }^{331}$ B.a., Nowe Elementy $w$ Rosyjskim Stanowisku Wobec Konfliktu $w$ Naddniestrzu, OSW, accessed online 12 September 2012, http://www.osw.waw.pl/pl/publikacje/tydzien-na-wschodzie/2008-06-04/nowe-elementy-wrosyjskim-stanowisku-wobec-konfliktu-w-na

${ }^{332}$ Witold Rotkiewicz, Zamrożony konflikt w Naddniestrzu: czyżby szansa na porozumienie?, OSW, Accessed online 12 September 2012, http://www.osw.waw.pl/pl/publikacje/komentarze-osw/2008-03-10/zamrozony-konfliktw-naddniestrzu-czyzby-szansa-na-porozumienie
} 
and his abandonment of pro-European course was a sign of common sense and was consistent with the country's political position. ${ }^{333}$ His warm feelings toward Moscow had translated to the favorable treatment in negotiating the country's energy debt and prices. When Moldovan ViceMinister Zinaida Greciani arrived at the Kremlin to discuss this question, Russia announced the possibility of reconsidering its energy prices strategy. Although one could argue that this cannot be called a successful negotiation, but taking under consideration the size of debt that amounted for 1,8 mil dollars, any concession on that matter could be called a victory. ${ }^{334}$ But as always the Kremlin's promises had their own price. Pursuant to Russia's will Voronin did not attend GUAM summit in Batumi on July 1, 2008 and instead sent the country's deputy minister of foreign affairs and European integration, Valeriu Ostalep. ${ }^{335}$

\section{Elections crisis. Moldovan Communists lose power}

Nevertheless, the Communist Party's efforts to strengthen ties with Moscow were also dictated by the wider political strategy of the party whose major goal was to win the upcoming parliamentary elections in 2009. Indeed, as shown earlier, the Russian support has always been an important factor in Moldovan elections. By pursuing the pro-Russian policies and thus finally settling the long-lasting conflict in the region Voronin and his party would have had the election victory sewn up. Russia on the other hand, by supporting Communist Party could pursue its own

\footnotetext{
${ }^{333}$ Kaljurand, Russian Influence on Moldovan Politics during..., p.12.

${ }^{334}$ B.a., Premier Mołdawii z Gospodarcza Wizyta w Moskwie, OSW, accessed online 14 September 2012, http://www.osw.waw.pl/pl/publikacje/tydzien-na-wschodzie/2008-06-25/premier-moldawii-z-gospodarcza-wizyta-wmoskwie

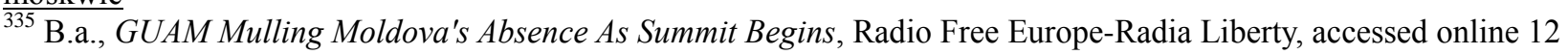
September 2012, http://www.rferl.org/content/Mulling_Moldovas_Absence_As_GUAM_Summit_Begins/1181026.html
} 
foreign policy, which translated into maintaining dominance in the region and preventing the Western players from becoming involved. That is why on February 24, 2009 the Russian Foreign Minister came to Kishinev to emphasize Moscow's support for Communist Party and its leader. Lavrov used also the opportunity of pre-election tensions and tried to encourage Kishinev to eliminate the UE and USA from the negotiations and focus on a tri-lateral settlement. ${ }^{336}$ Furthermore, in order to boost Voronin's chances Russia offered 500 million dollars per month before the July elections. ${ }^{337}$ Modlova did not take up the offer of the loan but instead agreed on conducting three-sided negotiations, Kishinev-Tiraspol-Moscow without the presence of Western co-mediators. Moreover, on March 18, 2009 during the meeting of Medvedev with Smirnof and Voronin, the latter eventually accepted the current format of the peacekeeping mission in Transnistira, resigning from the previous plan to replace Russian troops with an international civilian mission. ${ }^{338}$

However, this effort to please Russia and most of all Russian and pro-Russian voters did not bring the expected results during the parliamentary elections on 5 April 2009. As a result of the elections the Communist Party won the majority of the seats, 60 out of 101, but was not able to elect a new president, as the new president, which required a three-fifths of parliamentary majority. Because none of the opposition representatives wanted to vote in favor of the Communists candidate, Zinaida Greciani, Voronin was forced to dissolve the Parliament and set early elections for July 29 , the same year. ${ }^{339}$ Russian authorities wanting to assure that this time PCRM will win the required 61 seats, once again expressed their support for Voronin's party and

\footnotetext{
${ }^{336}$ B.a., Moskwa aktywizuje Wysilki w Mołdawii, OSW, accessed online 30 August 2012, http://www.osw.waw.pl/pl/publikacje/tydzien-na-wschodzie/2009-02-25/moskwa-aktywizuje-wysilki-w-moldawii

${ }^{337}$ Crandall, Hierarchy in Moldova-Russia Relations..., p.8.

${ }^{338}$ Witold Rodkiewicz, Kreml przejmuje inicjatywe w sprawie Naddniestrza, accessed online 12 September 2012, http://www.osw.waw.pl/pl/publikacje/tydzien-na-wschodzie/2009-03-25/kreml-przejmuje-inicjatywe-w-sprawienaddniestrza

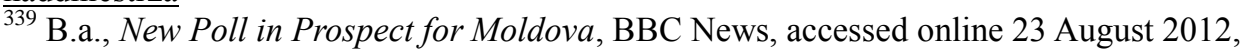
http://news.bbc.co.uk/2/hi/europe/8080886.stm
} 
repeated its loan offer. This did not help out the Communists in the July elections. This time they won 12 seats less than the last time, that were transferred to the opposition coalition, Alliance for European Integration (AEI). As a result it was the opposition parties oriented to the West that won with a slender majority. ${ }^{340}$ On top of that in September 2009 Voronin resigned after 8 years in the office and passed the role of acting President to the current speaker of parliament, Liberal Party leader Mihai Ghimpu, until a new presidential election could be held in parliament. ${ }^{341}$ Unfortunately this move "ended in a stalemate." 342 The Parliament was not able to select a new President for almost three years during which the country was plunged into the serious political crisis.

The results of the July election took Russian leaders by surprise. The victory of the European oriented parties striving for reconciliation with Romania was a real threat to Russian dominance in the region. Andrei Makarychev of the Nizhny Novogrod Civil Service Academy claimed that "the defeat of the Communist Party of Moldova in the repeat parliamentary election of 2009 and the resignation of President Vladimir Voronin have deeply challenged Russia's position in this geographically small, yet politically very important, country... and made Moscow reshape its policies toward Chisinau." ${ }^{343}$ Indeed, in the aftermath of the announcement of the election results, the most important Kremlin leaders, President Medvedev, Minister Lavrov and Russian Minister of Finance Aleksei Kudrin rushed to Kishinev under the veil of an upcoming CIS summit in the capital. To the surprise of all Medvedev met with Marian Lubu, the AEI

\footnotetext{
${ }^{340}$ Ozgehan Senyuva, Parliamentary elections in Moldova, April and July 2009, accessed online 20 September 2012, http://www.ces.metu.edu.tr/docs/ozgehan_article.pdf

${ }^{341}$ B.a., Voronin To Resign As Acting Moldovan President, Radio Free Europe/Radio Liberty, accessed online 02 September 2012, http://www.rferl.org/content/Acting_Moldovan_President_Voronin_Reportedly_Resigns/1812942.html

${ }^{342}$ Diana Toma, Markus Salzmann, Political Crisis in Moldova Intensifies after Election, wsws.org, accessed online 02 September 2012, http://www.wsws.org/articles/2010/dec2010/mold-d14.shtml

${ }^{343}$ Andrey Makarychev, Russia's Moldova Policy Soft Power at the Service of Realpolitik?, Ponars, accessed online 01 September 2012, http://www.gwu.edu/ ieresgwu/assets/docs/pepm_094.pdf
} 
Presidential candidate and officially invited him for the CIS meeting. By doing so Moscow showed that its priority was to maintain a strong influence in the country no matter ruled it, Communists or Nationalists. At the same time the Kremlin's diplomacy underlined that the new Moldovan leadership could not count on Russia changing its mind on the presence of Russian troops and would be grateful if the AEI accepted the "Kozak Memorandum" from 2003. ${ }^{344}$ They mentioned Kozak's proposal on purpose. Their main goal was to show dissatisfaction with the election's outcome and that in such new circumstances Russia was not going to continue the policy of concessions. Aside of from traditional foreign policy instruments like blackmail, Moscow introduced also a new "soft power approach" aimed at strengthening the Russianelement in the country. Russia decided to get what it wanted by using persuasion rather than coercion, for instance, by economic assistance and cultural exchanges. ${ }^{345}$ Thereby Moscow financed pro-Russia movements like "Novaia Moldova" of "Russia’s Friend” as well as repeated its pre-election loan offer.

At first the Russian approach worked perfectly. The Western- oriented government agreed on February 2010 to extend the existing agreement on the energy supplies with the Power plant in Transnistria owned by Russian concern Inter RAO JES. ${ }^{346}$ Thereby the new leadership showed that it was going to continue the energy policy commenced by Voronin and allowed Moscow to maintain full control over Moldova's energy sector. Yet the impasse in the Russian-Moldovan relations began again two months latter. The crisis was caused by the acting President Mihai Ghimpu, decision, not to attend the celebrations of the $65^{\text {th }}$ anniversary of the victory in II World

\footnotetext{
${ }^{344}$ Witold Rodkiewicz, Kreml Walczy o Utrzymanie Swoich Wpływów w Mołdawii, OSW, accessed online 10 September 2012, http://www.osw.waw.pl/pl/publikacje/tydzien-na-wschodzie/2009-10-14/kreml-walczy-outrzymanie-swoich-wplywow-w-moldawii

${ }^{345}$ Kaljurand, Russian Influence on Moldovan Politics during the Putin Era...,p.6.

${ }^{346}$ Nowy Rzad kontynuuje Politykę EnergetycznegoUuzależnienia Mołdawii od Rosji, OSW, accessed online12 September 2012, http://www.osw.waw.pl/pl/publikacje/tydzien-na-wschodzie/2010-03-03/nowy-rzad-kontynuujepolityke-energetycznego-uzaleznienia
} 
War in Moscow. ${ }^{347}$ This decision was strictly related with the upcoming parliamentary elections and revealed the real ambitions of some of the pro-Western politicians. In face of this political statement on the part of the coalition in power and the elections in November the same year Russia decided to confound the pro-Western AEI and thus again back the Moldovan Communists. In order to do so on July 19, 2010 the Chief of the Sanitary Inspection Giennadi Onishchenko announced the reintroduction of a ban on Moldovan wine. Furthermore, as in 2005, the embargo was followed by a ban on fruits and vegetables. Those political actions did not bring the expected result though. In the fourth-parliamentary election in two years the governing coalition gained 59 seats, while the PCRM received only 42 mandates. ${ }^{348}$ Moreover, the government remained almost the same and an the no longer favored by Moscow Vlad Filat was reappointed a Prime Minister. $^{349}$

The entire decade of the Russian-Moldovan relations was therefore marked alternately by the successes and failures of Russian diplomacy in maintaining dominance in Moldova. When in 2001 the Communist Party headed by Vladimir Voronin came to power one would assume that having things in hand would be an easy task for Kremlin. Yet it seemed that Russia overestimated Voronin's pro-Russian stance, ignoring his European aspirations and political consciousness. However, it proved later that the hard power instruments toward Kishinev worked very well and the Moldovan government returned to a pro-Russian course. Not without unpleasant consequences, however. The constant political and economic sabotage and dual strategy toward Western players resulted in Russia's lost of credibility in the eyes of the Moldovan society and

\footnotetext{
${ }^{347}$ B.a., Udziat w Defiladzie Zwycięstwa w Moskwie dzieli Rzadzaca Koalicję w Mołdawi, OSW, accessed online 02 July 2012, http://www.osw.waw.pl/pl/publikacje/tydzien-na-wschodzie/2010-04-28/udzial-w-defiladzie-zwyciestwaw-moskwie-dzieli-rzadzaca-

${ }^{348}$ Vera Ragone, Moldova: Between Political Stalemate and International Negotiations (Milano:Instituto Per Gli Studi Di Politica Internazionale, 2011),p.3.

${ }^{349}$ Ibid.
} 
the international community. Nevertheless, during the ten years Kremlin managed to achieve some of Putin's foreign policy goals. It took almost full control over the Moldovan energy sector and was able to maintain strong influence in Transnistira. Moldova, on the other hand, turned out to be less successful in pursuing its objectives. It had lost on every front, beginning with European integration. 


\section{Conclusion}

\section{Current Situation in Brief}

The Russians' striving over maintaining strong influence on political life in the Republic of Moldova has continued. The areas in which the Russian authorities have been using their tools in order to pursue Moscow's interests also remained unchanged: the issues of Transnistria, energy supplies and trade regulations. The last 20 years of Moldova- Russian relations prove that whenever, as during the early elections organized due to the Parliament's incapability to select a President, the pro-Russian camp was loosing mandates, Moscow, instead of strengthening its position by using soft power, decided more often to use political and economic sabotage in order to keep the region within Russian sphere of influence. The resolution of Transnistria conflict and the presence of the Russian peacekeeping mission are the main issues of Moldova-Russia relations recently. For instance, when the pro-European coalition won the parliamentary elections in Moldova at the end of November 2010 the Kremlin refused to continue the negotiations over the DMR issue in order to show that the Russians believed that only the Communist Party would be capable of carrying out the talks. But only recently has it turned out that the Western oriented parties have not been the only factor that have been disturbing Russian domination in the country.

DMR leaders began to formulate their own independent policy toward the government in Kishinev, not necessarily synchronized with the one performed by Moscow. Since the last thing 
Smirnof wanted the reunion of the breakaway region with the rest of the Republic (which was the main goal of the Russia-initiated negotiations), the lack of understanding between AEI and Putin well corresponded with his interests. That is why Smirnof openly supported the Moldovan proEuropean government in order to remain the only guarantor of the Russian interest in the region. For instance, the invitation of the President of the breakaway region to Prime Minister Filat to jointly attend the international football game in Tiraspol was a clear demonstration of divergence between Transnistria's and Russia's approach toward the government in Kishinev .

This, again, set in motion the traditional mechanism of Russian foreign policy towards Kishinev. On February 2011 the Russian Ambassador to Moldova, Valeri Kuzmin, suggested that Gazprom could rethink the announced increase in gas prices if Kishinev agreed to accept the Russian military presence in the DMR. ${ }^{350}$ This offer was not aimed only at stressing that no deal could be made behind Moscow's back but most notably at strengthening the division among the pro-European coalition's parties, between supporters and opponents of intensification of cooperation with the Kremlin before elections planned for November 2011. Putin's government also did not hesitate to show its dissatisfaction with the political decision of the Democratic Party of Moldova, which had chosen to unify with pro-Romanian party headed by Filat instead of forming a coalition with Voronin. Therefore, when Lupu arrived in Moscow for an official visit as speaker of the Moldovan Parliament none of the Russian newspapers even mentioned his visit while the meeting of speaker of DMR Parliament, Anatolii Kaminski, with Russian leaders was widely commented in local media. ${ }^{351}$

Meanwhile Tiraspol continued conducting an independent policy toward the Western oriented central government. Smirnof was even able to muster its support for initiating the peace

\footnotetext{
${ }^{350}$ B.a., Rosyjskia Oferta dla Mołdawii, OSW, accessed online 13 September 2012, http://www.osw.waw.pl/pl/publikacje/tydzien-na-wschodzie/2011-02-09/rosyjska-oferta-dla-moldawii

${ }^{351}$ Ibid.
} 
negotiations, without any assistance from Moscow, in exchange for lifting the trade restrictions. ${ }^{352}$ But according to the specialists from the Center of Eastern Studies in Warsaw the current offer was just a carrot on the stick that was supposed to enable DMR authorities to gain significant economic privileges in exchange for empty political promises. ${ }^{353}$ The answer from Moscow was a sudden removal of endorsement for Smirnof and an announcement of support for the new Presidential candidate of DMR, Anatolii Kaminski.

The empty promises also characterized the Russian approach towards the Moldovan leadership. For example, Moscow invited Kishinev to sign the CIS Free Trade Agreement on February 10, 2012. Although theoretically the Free Trade Agreement was supposed to put an end to the constant economic sabotage performed by Russia, the document was full of exclusions from the Free Trade Zone that included the most important trade products like agriculture products, alcohol and, of course, gas. At the same time it's important to remember that the offer to join the Zone was an element of the Russian pre-election campaign in Moldova that was aimed at supporting the pro-Russian political element. Finally, on 16 March 2012, after the stalemate that had lasted for almost 3 years, AEI managed to nominate a new President, Supreme Magistrate Council Chair and Judge Nicolae Timofti, and by doing so it confirmed Moldova's European ambitions. As usual this did not go without unpleasant consequences for Republic of Moldova. Right after the nomination the Russian Minister of Defence Anatolij Sierdiukow and the Special Representative for Transnistria Dimitri Rogozin rushed to the breakaway region to confirm Russia's vital economic and political interests in the DMR. Russian officials did not

\footnotetext{
${ }^{352}$ B.a., Naddniestrze przedstawia warunki wznowienia rokowań z Kiszyniowem, OSW, accessed online 17 September 2012, http://www.osw.waw.pl/pl/publikacje/tydzien-na-wschodzie/2011-03-02/naddniestrze-przedstawiawarunki-wznowienia-rokowan-z-kis

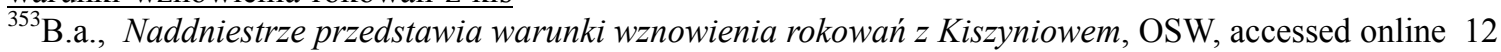
September 2012, http://www.osw.waw.pl/pl/publikacje/tydzien-na-wschodzie/2011-03-02/naddniestrze-przedstawiawarunki-wznowienia-rokowan-z-kis
} 
inform the government in Kishinev about the visit which was a clear statement that the Kremlin was going to ignore the theoretical integrity of the two entities. Moreover, just recently Moscow urged Moldova to quit the EU Energy Cooperation Agreement. On September 12, 2012 the Russian Energy Minister Alexander Novak told reporters "First of all, we propose that Moldova denounce the protocol on entering the Europe energy community agreement. This is a precondition for us to discuss the issue of gas price cuts and the relief of debt, which at the moment amounts to $\$ 4.1$ billion., 354

\section{What next?}

When in 2009 the Alliance for European Integration came to power in Moldova most of the observers announced a new era in the relations between governments in Kishinev and Moscow. For the first time the Russian influence in Moldova became significantly threatened as Kishinev stated its serious interest in the European integration. Taking into consideration Russia's geopolitics the election's results started the beginning of political and economic turmoil in the region. Yet, even after the pro-European parties came to power relations did not change much and were basically characterized by usual ups and downs. Why? It seemed like none of the Moldovan factions could really commit to either the Eastern or Western side, balancing between them constantly. Kaljurand went even further, describing the leaders in Kishinev as "corrupt and authoritarian playing a rather pragmatic game of perpetual maneuvering between East and West

\footnotetext{
${ }^{354}$ B.a., Russia Pressures Moldova to Quit EU Energy Cooperation for Discount, Kanal PIK, accessed online 17 September 2012, http://pik.tv/en/news/story/47214-russia-presses-moldova-to-quit-eu-energy-cooperation-agreement
} 
to strengthen their own position." ${ }^{355}$ They kept sending contradictory messages to their Russian partner and the European Union and that is why the country lost the credibility in the eyes of international players.

Yet it can be argued that in his conclusions Kaljurand went too far. One cannot forget that Moldova's turbulent history as well as its current geopolitical position did not allow Kishinev to ignore Moscow. Aside from the obvious energy dependence, Moldova had to struggle with the „frozen conflict" on its territory, that was controlled military by the outside forces. Understandably, those two factors were determinative in forming foreign policy toward Russian Federation. The small, impoverished and politically unstable country could not resist the influences of the "superpower in the territory of former Soviet Union" that uses its energy domination and military presence to sabotage the domestic and foreign politics. ${ }^{356}$ On top of that Moldova deeply depended on the export of agriculture products to Russia with its wine industry estimated to account for somewhere near 25 percent of Moldova's gross domestic product (GDP), with 80 percent of that wine exported to Russia. ${ }^{357}$ Therefore, at least for now, with no strong support from the West the hands of the Moldovan leaders are tied and they have to adjust their political decision with an eye on the Kremlin.

Russia, on the other hand, was simply pursuing its own numerous interests in the region. The first was to maintain the historical ties with the region inherited from Russian Empire and Soviet Union, which included the economic resources and the population of Russian desent. However, it is important to notice the fact that Russian actions had nothing to do with neoimperialist ambition or expansionism. The leaders in Moscow want to ensure that Moldova will stay within the Russian sphere of influence and thwart the danger of closer relations between

\footnotetext{
${ }^{355}$ Kaljurand, Russian Influence on Moldovan Politics during the Putin Era...,p.12.

${ }^{356}$ Herd, Moldova and the Dniestr Region ..., p.14.

${ }^{357}$ Kennedy, Moldova: Counting Losses As Russian Wine Ban Lingers... .
} 
Moldova Western organizations like NATO or EU. That is why that the political and economic leverage will probably remained the major tool in Russian foreign policy toward Moldova.

Is it possible to break the impasse in the Russian-Moldovan relations? The only answer would be the intensified involvement of Western players, especially the European Union. Taking under consideration Kishinev's current efforts to come closer to European integration, EU engagement in the region is the only way to balance Russian influence. However, this would require the European states to engage strongly in the region, especially in the settling the Transnistrian conflict. But even more importantly this would require the EU to formulate a new strategy toward the region that would be linked more with Russian policy toward the "shared neighborhood". For now the lack of communication between Brussels and Moscow results in causing political crisis in the region that is sandwiched between two regional centers. 


\section{Bibliography}

\section{Primary sources}

Agreement on the Establishment of the CIS 1991, (2/1991, Kishinev,8 December 1991), accessed online 31 March 2012, http://cis.minsk.by/reestr/ru/index.html\#reestr/view/text?doc=1

Constitution of Republic of Moldova 1994, July 291994 , accessed online 21 April 2012, http://confinder.richmond.edu/admin/docs/moldova3.pdf

Documenty vneshnei politiki S.S.S.R., volume 7. Moscow, 1963

Pervaia vsesoiuznaia perepis' naselenia Rossiskoi imprerii, 1897 g., Vol. 20, S. Petersburg, Bessarabskaia gubernia, 1905.

10 ani de construire socialista a RASSM, Tiraspol: Editura de Stat a Moldovei, 1934.

Brezhnev, Leonid Il'ich. Vaspominaniia. Moscow: Izdatel'stvo politicheskoi literatury, 1983.

Kuropatkin Aleksey. Zadechi Russkoy Armii. St. Petersburg : Vol. 2, 1910.

Seton-Watson Robert William. The history of Roumanians: From Roman Times to the 
Completion of Unity. 1963.

Surilov Alexander ed. Gosudarstvenno - pravovye akty Moldavskoi SSR. Chisinau: Cartea Moldovenesca, 1963.

\section{$\underline{\text { Secondary sources }}$}

B.a., 1999: Putin takes over as Yeltsin resigns, BBC News, accessed online :

http://news.bbc.co.uk/onthisday/hi/dates/stories/december/31/newsid_4102000/4102107.stm

B.a., Context of 'December 31, 1999: Yeltsin Resigns; Putin Now Acting President of Russia, History Commons, accessed online:

http://www.historycommons.org/context.jsp?item=a123199yeltsinresignation

B.a., Country Report Moldova, EIU, No. 1 2000, 8.

B.a., Energetyczna gra: Ukraina, Mołdawia i Białoruś między Unią a Rosja , Warszawa: Fundacja im. Stefana Batorego, 2007.

B.a., GUAM Mulling Moldova's Absence As Summit Begins, Radio Free Europe-Radia Liberty, accessed online:

http://www.rferl.org/content/Mulling_Moldovas_Absence_As_GUAM_Summit_Begins/1181026 .$h t m l$ 
B.a., Interview with President Mircea Snegur, BASA-press, accessed online: www.basa.md B.a., Dividing up Moldovagaz and Moldova's gas debts, OSW, accessed online: http://www.osw.waw.pl/en/publikacje/eastweek/2011-03-30/dividing-moldovagaz-and-moldovas-gas-debts

B.a., Memorandum ob Osnovnykh Principiakh Gosudarstvennogo Ustroistva Obedinionnego Gosudarstva, RIA Novosti, accessed online: http://visualrian.ru/ru/site/video/news/

B.a., Moldova Communists Stay in Power, BBC News, accessed online : http://news.bbc.co.uk/2/hi/europe/4322617.stm

B.a., Moldova: Economic Trends, Quarterly Issue, January-March 1998 , Brussels: European Commission, 1998.

B.a., Moldova: Regional Tensions over Transdniestria , Brussels: International Crisis Group, European Report nr. 157.

B.a., Moldova - Narrative: Origins, Background and Conditions of the Moldova-Niester Conflict, University of Southern California, accessed online: http://www.usc.edu/dept/LAS/ir/cews/database/Moldova/moldova.pdf . 
B.a., Moldova's Parliament Ratifies Agreement On Military Cooperation With Russia, Pravda.ru, accessed: http://english.pravda.ru/news/world/ussr/20-04-2001/40646-0/

B.a., Moldova: Regional Tensions over Transdniestria, Brussels: International Crisis Group, European Report nr. 157.

B.a., Moldovan Wine Back in Russia after Ban, Reuters, accessed online: http://uk.reuters.com/article/2007/11/01/uk-moldova-russia-wine-idUKL0142079420071101

B.a., Moskwa aktywizuje Wysiłki w Mołdawii, OSW, accessed online: http://www.osw.waw.pl/pl/publikacje/tydzien-na-wschodzie/2009-02-25/moskwa-aktywizujewysilki-w-moldawii

B.a., Naddniestrze przedstawia warunki wznowienia rokowań z Kiszyniowem, OSW, accessed online : http://www.osw.waw.pl/p1/publikacje/tydzien-na-wschodzie/2011-03-02/naddniestrzeprzedstawia-warunki-wznowienia-rokowan-z-kis

B.a., New Poll in Prospect for Moldova, BBC News, accessed online: http://news.bbc.co.uk/2/hi/europe/8080886.stm

B.a., Nowe Elementy w Rosyjskim Stanowisku Wobec Konfliktu w Naddniestrzu, OSW, accessed online : http://www.osw.waw.pl/pl/publikacje/tydzien-na-wschodzie/2008-06-04/noweelementy-w-rosyjskim-stanowisku-wobec-konfliktu-w-na 
B.a., Nowy Rząd kontynuuje Politykę EnergetycznegoUuzależnienia Mołdawii od Rosji, OSW, accessed online: http://www.osw.waw.pl/pl/publikacje/tydzien-na-wschodzie/2010-03-03/nowyrzad-kontynuuje-polityke-energetycznego-uzaleznienia

B.a., Pochemu ne był podpisan Memorandum po pridnestrovskomu uregulowaniu- Interview with Vladimir Voronin, Kishinev: Logos Pres, 28 November 2003.

B.a., Premier Mołdawii z Gospodarcza Wizytą w Moskwie, OSW, accessed online: http://www.osw.waw.pl/pl/publikacje/tydzien-na-wschodzie/2008-06-25/premier-moldawii-zgospodarcza-wizyta-w-moskwie

B.a., Rosja gotowa do kompromisu w sprawie Naddniestrza?, OSW, accessed online: http://www.osw.waw.pl/pl/publikacje/tydzien-na-wschodzie/2008-03-05/rosja-gotowa-dokompromisu-w-sprawie-naddniestrza

B.a., Rosyjskia Oferta dla Mołdawii, OSW, accessed online : http://www.osw.waw.pl/pl/publikacje/tydzien-na-wschodzie/2011-02-09/rosyjska-oferta-dlamoldawii

B.a., Russia considers sanctions against Moldova, Ireland Online, accessed online: http://www.freerepublic.com/focus/f-news/1365557/posts 
B.a., Russia Pressures Moldova to Quit EU Energy Cooperation for Discount, Kanal PIK, accessed online: http://pik.tv/en/news/story/47214-russia-presses-moldova-to-quit-eu-energycooperation-agreement

B.a., Russian-Moldovan talks, Isvestia, October 30,( 1991),No. 1.

B.a., Russian trade sanctions against Georgia, Moldova and Ukraine, Moldova.org, accessed online : http://economie.moldova.org/news/russian-trade-sanctions-against-georgia-moldova-andukraine-12562-eng.html

B.a., The putsch of August 22,1991, Russia the Great, accessed online: http://russia.rin.ru/guides_e/7227.html

B.a., Snegur Interviewed on Dniestr Conflict, FBIS Daily Report - Central Eurasia Vol. 2, June 1992.

B.a., Pro-Russian Wins Moldova Presidency, The Los Angeles Times, December 3 2011, access online, http://articles.latimes.com/1996-12-03/news/mn-5297_1_moldova-presidency

B.a., Udział w Defiladzie Zwycięstwa w Moskwie dzieli Rządzạcą Koalicję w Mołdawi, OSW, accessed online: http://www.osw.waw.pl/pl/publikacje/tydzien-na-wschodzie/2010-04-28/udzialw-defiladzie-zwyciestwa-w-moskwie-dzieli-rzadzaca- 
B.a., Voronin To Resign As Acting Moldovan President, Radio Free Europe/Radio Liberty, accessed online:

http://www.rferl.org/content/Acting_Moldovan_President_Voronin_Reportedly_Resigns/1812942 .html

Akerman Ellen, Implications of the Russia's foreign security policy on Moldova , Aberdeen: Scotish Centre for International Security, 2003.

Ataman Yuri, A case Study on Mediation Process in Moldova/Transdniestria , Stockholm: International Peace Research Center, 1998.

Atorina Lubov Andeevna, Specyfika Otnashenii Rossii i Stran, Moscow: MGU, 2010.

Baev Pavel, The Russian Army in the Time of Troubles, Oslo: International Peace Research Institute, 1996.

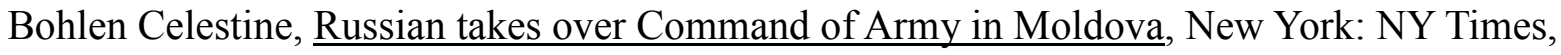
April 21992.

Borgen Christopher, Thawing a Frozen Conflict: Legal Aspects of the Separatist Crisis in Moldova New York: The Association of the Bar of the City of New ,2006. 
Botan Igor, Sankt-Petersburg CIS Summit, Democracy.md, accessed online : $\underline{\text { http://www.e- }}$ democracy.md/en/monitoring/politics/comments/200806151/

Brezianu Andrei. Historical Ductionary of Republic of Moldova. Lanhaim: The Scarecrow Press, 2000

Bruchis Michael. The Republic of Moldova: From the Collapse of the Soviet Empire to the Restoration of the Russian Empire. New York: Columbia University Press, 1996.

Crandall Matthew, Hierarchy in Moldova-Russia Relations: the Transnistrian Effect, Tallin: Studies of Transition States and Societies, Vol 4, 2008.

Crawshaw, Steve, Goodbye to the USSR: The Collapse of Soviet Power, London: Bloomsbury, 1992.

Crow Suzanne, Russian Moderates Walk a Tightrope on Moldova, RFE/RL Research Raport, vol 1, no. 20, 15 May 1992.

Dima Nicholas. Bessarabia and Bukovina: The Soviet - Romanian Territorial Dispute. New York: Colambia University Press, 1982. 
Fane Daria. "Appendix B Soviet census data, union republic and ASSR 1989”, Nations and Politics in the Soviet Successor States, Eds. Ian Bremner and Ray Tarras, Cambridge: Cambridge University Press, 1993.

Fedor Helen ed..Belarus and Moldova : Country Studies. Washington, D.C. : Library of Congress, 1995.

Godzimirski Jakub, Russian National Security Concept 1997 and 2000: A Comperative Analisis, London: European Security, Vol.9, 2000.

Gotisan Iurie, Chisinau's economic dependence on Moscow, Associacion for Participatory Democracy, accessed online: http://www.edemocracy.md/en/comments/socioeconomic/200505041/

Grosol Vladimir, Istoria Pridnestrovskoj Moldavskoj Respubliki, Tiraspol: Transnistrian Institute of the Continuing Education, 2001.

Herd Graeme P., Moldova and the Dniestr Region: Contested Past, Frozen Present, Speculative Futures?, Surrey: Defense Academy of United Kingdom, 2005.

Hill Ronald J. Soviet Political Elite. The Case of Tiraspol. New York: St. Martin Press, 1977. 
Ionescu Don, Soviet Moldova: A breakthrough in the Alphabet Issue, Chisinau: RFE Research, 1989.

Isaev Alexander, Rossia - Moldova: Sozdany Predposylki dlia Razvitia Ekonomicheskikh Sviazei, Kishinev: NM, 22 November 2001.

Jackowicz Jerzy, Mołdawia 1997-1998, Warszawa” Rocznik Europy Środkowo-Wschodniej, 1999.

Jewsburry George F. The Russian annexation of Bessarabia 1777 - 1828. A Study of Imperial Expansion. Boulder Colorado: East European Monographs, No. 28, 1977.

Kaljurand Riina, Russian Influence on Moldovan Politics during the Putin Era (2000-2008), Tallin: International Centre for Defense Studies, 2008.

Kennedy Ryan, Moldova: Counting Losses As Russian Wine Ban Lingers, Radio Free Europe/Radio Liberty, accessed online : http://www.rferl.org/content/article/1075697.html

Kharas Homi, Pinto Brian, and Ulatov Sergei, An Analysis of Russia's 1998 Meltdown:

Fundamentals and Market Signals, Washington : Brookings Papers on Economic Activity, 2001.

King Charles, Post-soviet Moldova: A Borderland in Transition, Stanford: Center for Romanian Studies, 1997. 
King Charles. The Moldovans: Romania, Russia, and the Politics of Culture. Stanford: Hoover Institution Press, 2001.

Kolso Paul, Edemsky Andrei, and Kalashnkova Natalya The Dniester Conflict: Between Irredentism and Separatism, Glasgow: Europe-Asia Studies, 1993.

Kuchler Florian, The Role of the European Union in Moldova Transnistrian Conflict, Stuttgard: Ibidem-Verlag, 2008.

Lowenhardt John, The OSCE, Moldova and Russian Diplomacy in 2003, The Hague: Clingendael Institute,2004.

Lynch Allen C., The Evolution of Russian Foreign Policy in the 1990's , The Journal of Communist Studies and Transition Politics, vol 18, 2002.

Makarychev Andrey, Russia's Moldova Policy Soft Power at the Service of Realpolitik?, Ponars, accessed online : http://www.gwu.edu/ ieresgwu/assets/docs/pepm_094.pdf

Maksymiuk Jan, Analisis: Transnister wants Talks on 'Federal System' with Moldova, Radio Free Europe/Radio Liberty, accessed online: http://www.rferl.org/featuresarticle/2004/09/53bc0d6bd61b-49bb-8f7a-e563715de8b9.html 
Martin Terry, The Origins of Ethnic Cleansing, Chicago: The Journal of Modern History, Vol. 70, No. 4. Dec., 1998.

Matz John, Constructing a post-Soviet International Political Reality: Russian Foreign Policy Towards the Newly Independent States, 1990-95, Uppsala: Uppsala University, 2001.

Mitrasca Marcel. Moldova, A Romanian Province under Russian Rule: Diplomatic History from the Archives of the Great Powers. New York: Algora Publishing, 2002.

Morawiec Rafał, Mołdawia 1992, Warszawa: Rocznik Europy Środkowo-Wschodniej, 1993.

Morike Andrea, The Military as a Political Actor in Russia: the Cases of Moldova and Georgia, Kishinev: International Spector, 1998.

Nadris Grigore. Bessarabia and Bukovina. New York: Societatea pentru Cultua, 1968.

Nahaylo Bohdan, National Ferment in Moldova, RFE/RL Research Raport, vol 32, no. 20, 24 January 1988.

Neuman David, Boundaries, Territory and Postmodernity, London: Routledge Studies in Geopolitics, 1991.

Nistor. Istoria Bessarabiei. Bucharest:Humanitas, 1991. 
Nodia Ghia, Europeanization and (Not) Resolving Secessionist Conflicts, Journal of Politics and Minority Issues in Europe, vol. 5, no. 1., 2004.

Nygren Bertil, The Rebuilding of the Greater Russia, Putin's Foreign Policy towards the CIS Countries, New York: Routledge, 2008.

O’Loughlin John, Kolossov Vladimir, and Tchepalyga Andrei, “ National Construction, Territorial Separatism, and Post-Soviet Politics" in : the Transnistrian Moldovan Republic , New York: Post Soviet Geography and Economics 39, No 6, 1998.

Popovici Andrei. The Political Status of Bessarabia. Washington D.C.: Ransdell, 1931.

Ragone Vera, Moldova: Between Political Stalemate and International Negotiations, Milano:Instituto Per Gli Studi Di Politica Internazionale, 2011.

Riasanovsky Nicholas, Steinberg Mark, History of Russia Oxford: Oxford University Press, 1999.

Roper Steven D., "Regionalism in Moldova, The Case of Transdniestira and Gagauzia", ed. Oliver Schmidtke Europe's Last Frontier?: Belarus, Moldova, and Ukraine between Russia and the European Union, London: Palgrave Macmillan, 2007. 
Rodkiewicz Witold, Kreml przejmuje inicjatywę w sprawie Naddniestrza, accessed online: http://www.osw.waw.pl/pl/publikacje/tydzien-na-wschodzie/2009-03-25/kreml-przejmujeinicjatywe-w-sprawie-naddniestrza

Rodkiewicz Witold, Kreml Walczy o Utrzymanie Swoich Wpływów w Mołdawii, OSW, accessed online : http://www.osw.waw.pl/pl/publikacje/tydzien-na-wschodzie/2009-10-14/kreml-walczy-outrzymanie-swoich-wplywow-w-moldawii

Rotkiewicz Witold, Zamrożony konflikt w Naddniestrzu: czyżby szansa na porozumienie?, OSW, accessed online: http://www.osw.waw.pl/pl/publikacje/komentarze-osw/2008-03-10/zamrozonykonflikt-w-naddniestrzu-czyzby-szansa-na-porozumienie

Senyuva Ozgehan, Parliamentary elections in Moldova, April and July 2009, accessed online: http://www.ces.metu.edu.tr/docs/ozgehan_article.pdf

Shoemaker Wesley Merle, Russia and the Commonwealth of Independent States, Harpers Ferry: Stryker-Post Publications, 2006.

Skordas Achilles, Transniestria: Another Domino on Russia's Periphery?, New Heven: Yale Journal pf International Affairs, 2005.

Skvortova Alla, Country Report Moldova, Center for Applied Policy Research at University of Munich, accessed online: http://www.cap.lmu.de/download/2003/2003_Skvartova.pdf 
Smith Jr. Robert J., Russia and Moldova: Developing Relations between Two Countries

,Monterey: Naval Postgratuate School, 1993.

Socor Vladimir, Moldova Builds a New State, Radio Free Europe/Radio Liberty, accessed online http://www.rferl.org/search/?st=article\&k=socor\&df=07\%2F27\%2F1993\&dt=09\%2F27\%2F 1995 $\underline{\& o b=r e l \# \text { article }}$

Socor Vladimir, Moldova facing Russian Pressure, RFE/RL Research Raport, vol 1, no. 52, 15 December 1992.

Socor Vladimir, Moldova's New: Government of National Consensus, RFE/RL, accessed online : http://www.rferl.org/search/?k=socor\#article

Socor Vladimir, Moldova not to sign CIS Charter, RFE/RL, 8 December 1991.

Socor Vladimir, Moldovan President appeals to UN, RFE/RL Daily Report, vol. 1, no. 52, 3 August 1992.

Socor Vladimir, Russia Forces in Moldova, RFE/RL Research Raport, vol 1, no. 34, 28 August 1992.

Sowińska-Krupka Alicja , Mołdawia 1993, Warszawa: Rocznik Europy Środkowo-Wschodniej, 
1994.

Sowińska-Krupka Alicja, Mołdawia 1994-1995, Warszawa” Rocznik Europy ŚrodkowoWschodniej, 1996.

Sowińska-Krupka Alicja, Mołdawia 1996, Warszawa: Rocznik Europy Środkowo-Wschodniej, 1997.

Sowińska-Krupka Alicja, Mołdawia 1999, Warszawa: Rocznik Europy Środkowo-Wschodniej, 2000.

Spanu Vlad, GUAM: Background, Organization's future and Ukraine's role, Politcom, access online 16 October 2012: http://politicom.moldova.org/news/guam-background-organizationsfuture-and-ukraines-role-157816-eng.html

Spanu Vlad, Why is Moldova a Poor and Economically Volatile, Waschington DC: Moldova Foundation, 2004.

Taranetal. Aleksei, Golod v Moldove, 1946-1947: Sbornik Dokumentov. Chisinau: Stiinta, 1993.

Todua Zurab, Rasiia v Moldovii: Vernut' iniciatyvu, Rasiia v Globalnei Politike, No. 1 2007, accessed online : http://www.globalaffairs.ru/number/n_8148 
Toma Diana, Markus Salzmann, Political Crisis in Moldova Intensifies after Election, wsws.org, accessed online : http://www.wsws.org/articles/2010/dec2010/mold-d14.shtml

Torbakov Igor, Will Economic Sanctions Became a Legitimate Tool of Russian Roreign Policy?, Jemestown Fundation, accessed online:

http://www.jamestown.org/single/?no_cache=1\&tx_ttnews\%5Btt_news\%5D=32316

Upson Clark Charles, Bessarabia: Russia an Roumania on the Black Sea, New York: Dodd, Mead \& Company, 1927.

Quinlan Paul D., Moldova under Lucinschi, The George Waschington University, accessed online : http://www.gwu.edu/ ieresgwu/assets/docs/demokratizatsiya\%20archive/10-1_Quinlan.PDF, 99.

Walters Francis Paul. A History of the League of Nations, London: Oxford University Press, Vol. I, Article 10, 1952.

Wojciechowski Lech, "Mołdawia”, Rocznik Europy Środkowo-Wschodniej 2001-2002, Warsaw: ISP PAN, 2003.

Wojciechowski Lech, “Mołdawia “, Rocznik Europy Środkowo-Wschodniej 2003, Warsaw: ISP PAN, 2004. 
Wojciechowski Lech, "Mołdawia" in: Rocznik Europy Środkowo-Wschodniej, Warsaw: ISP PAN, 2006.

Wojciechowski Lech, "Mołdawia" in: Rocznik Europy Środkowo-Wschodniej 2006, Warsaw: ISP PAN, 2007.

Wojciechowski Lech, "Mołdawia" in: Rocznik Europy Środkowo-Wschodniej 2007, Warsaw: ISP PAN, 2008.

Wróbel Jacek, The European Union and Moldova, Warsaw: CES Studies, 2004.

Vahl Marius, Emerson Michael, Moldova and the Transnistrian Conflict, Flesburg: Journal of Ethno Politics and Minorities in Europe, 2004), No.1 2004.

Vessels Kendra Lea, Why is Moldova a country: Russia's Continued Influence in the Near Abroad, Austin: Report of the University of Texas, 2011.

Vitu, Liliana, Foreign affairs of the Republic of Moldova: Does Moldova's Eastern Orientation Inhibit its European Aspirations?, Chisinau: Institutul de Politici Publice, 2010.

Zafi, Davide. Moldavian-Russian Political Relations in Recent History. Centro Studi Sulla Storia Dell' Europa Orientale, Roma, 2002, access online: http://www.csseo.org/Papers/MoldovaDZ.pdf 